\title{
U. S. GEOLOGICAL SURVEY RADIOCARBON DATES V*
}

\section{MEYER RUBIN and CORRINNE ALEXANDER}

\author{
U. S. Geological Survey, Washington, D. C.
}

The dates listed herein have been determined at the U. S. Geological Survey radiocarbon laboratory at Washington since our last date list (USGS IV) and up to the end of 1959. Acetylene continues to be the gas of our choice. Each sample is run for a period of two days in two separate counters with separate electronics. The modern standard used is wood grown in the 19th century, and the ages and errors have been computed in the same manner as before. Pretreatment of wood, charcoal, and peat samples by boiling in acid, alkali, and acid again, is standard procedure.

\section{SAMPLE DESCRIPTIONS \\ I. GEOLOGIC SAMPLES \\ A. Eastern United States}

\section{W-828. Suffield, Connecticut}

Log from peat bog deposit, exposed in a ditch, just $E$ of runway of Bradley Field, Suffield ( $41^{\circ} 59^{\prime} \mathrm{N}$ Lat, $72^{\circ} 39^{\prime} \mathrm{W}$ Long), Connecticut. From base of bog on a delta built into glacial Lake Hitchock; the bog formed a small basin after the lake was drained. Coll. 1958 and subm. by R. B. Colton, U. S. Geological Survey, Denver, Colorado.

\section{Wallingford series, Connecticut}

Wood (Larix, id. by W. L. Stern) from pit in Wallingford, $4000 \mathrm{ft}$ W of U. S. highway $5 \mathrm{~A}, 1.2 \mathrm{mi} \mathrm{S}$ of school in South Meriden $\left(41^{\circ} 27^{\prime} \mathrm{N} \mathrm{Lat}, 72^{\circ}\right.$ 48' W Long), New Haven, Connecticut. Samples found at the contact of $14 \mathrm{ft}$ of till and clay with the bedrock. Some question exists as to whether the sediments from which the samples came are not in place or are included masses in the till. Yale's sample of the same wood, Y-451A and Y1451B, averaged 32,000 \pm 2800 (Yale III). Coll. 1956 and subm. by P. M. Hanshaw, U. S. Geological Survey, Denver, Colorado.

W-518. Wallingford, trunk

Part of tree trunk from sandy clay at contact of bedrock.

W-519. Wallingford, branch

Branch of tree from same location as W-518.

\section{Submerged forests series, Maine}

Tree stumps, in place, found submerged ca. $2 \mathrm{ft}$ below maximum low tide. These represent forests of considerable extent and indicate time or times of relative lowering of sealevel. Coll. 1956 by A. M. Hussey, II; subm. by W. H. Bradley, U. S. Geological Survey, Washington, D. C.

W-508. Wells Beach, Maine

Tree stumps from below low tide at Wells Beach $\left(43^{\circ} 20^{\prime} \mathrm{N}\right.$ Lat, $70^{\circ} 34^{\prime}$ W Long), York, Maine.

* Publication authorized by the Director, U. S. Geological Survey. 
W-509. Kennebunk Beach West, Maine

Tree stumps below low-water line on shore of Kennebunk Beach in cove $0.1 \mathrm{mi}$ E of Lords Point, Kennebunk Beach West $\left(43^{\circ} 21^{\prime} \mathrm{N}\right.$ Lat, $70^{\circ} 30^{\prime} \mathrm{W}$ Long), York, Maine.

W-510. Kennebunk Beach East, Maine

Tree stumps from below low-water line on beach of Naragansett Hotel, $0.8 \mathrm{mi}$ E of W-509, Kennebunk Beach East ( $43^{\circ} 21^{\prime} \mathrm{N}$ Lat, $70^{\circ} 30^{\prime} \mathrm{W}$ Long), York, Maine.

W-737. Waterville, Maine

$11,800 \pm 240$

Marine molluscs (Saxicava arctica and Panomya arctica) from marine clay exposed in gravel pit, $0.75 \mathrm{mi} \mathrm{SW}$ of Morrison Corner, $6.9 \mathrm{mi} \mathrm{N}$ of Waterville $\left(44^{\circ} 39^{\prime} \mathrm{N}\right.$ Lat, $69^{\circ} 36^{\prime} \mathrm{W}$ Long), Waterville Quadrangle, Maine. From a 2 -ft clay layer ca. $186 \mathrm{ft}$ above sealevel, overlain and underlain by sand and gravel. Coll. 1958 by R. L. Dow, Dept. of Sea and Shore Fisheries, State of Maine, Augusta; subm. by W. H. Bradley, U. S. Geological Survey, Washington, D. C.

W-522. Scituate, Massachusetts

Wood from $6 \mathrm{ft}$ above base of sea cliff at Fourth Cliff, Scituate $\left(42^{\circ} 12^{\prime}\right.$ N Lat, $70^{\circ} 44^{\prime}$ W Long), Scituate Quadrangle, Plymouth, Massachusetts. The cliff is made up of very compact till, cemented by iron and manganese oxides. Sample occurred in a lens of yellow and gray massive clay with some embedded sand and pebbles. Coll. 1956 and subm. by C. A. Kaye, U. S. Geological Survey, Boston, Massachusetts.

W-544. Harvard, Massachusetts

$21,200 \pm 1000$

Horn core of Bison crassicornis found in gravel pit on Depot Road 0.7 mi NNE of town of Harvard $\left(42^{\circ} 30^{\prime} \mathrm{N}\right.$ Lat, $71^{\circ} 35^{\prime} \mathrm{W}$ Long), Ayer Quadrangle, Massachusetts. Specimen, found in sand in kame terrace, $7 \mathrm{ft}$ below the surface, is believed to date the stand of the ice at Fort Devens, a few mi N. Sample was stored in a private home for $12 \mathrm{yr}$, then in the Museum of Comparative Zoology, Harvard University, for $6 \mathrm{yr}$. For discussion, see Romer (1951). Coll. 1938 by A Fanning; subm. by J. H. Hartshorn, U. S. Geological Survey, Boston, Massachusetts.

\section{Centerville series, Massachusetts}

Samples of peat and wood from the Centerville River, $\mathrm{S}$ of Centerville, at the site of the town landing $\left(41^{\circ} 38^{\prime} \mathrm{N}\right.$ Lat, $70^{\circ} 20^{\prime} \mathrm{W}$ Long), Massachusetts, to determine the rate of relative sealevel rise and the time when a cedar swamp was drowned by this rise. Coll. and subm. by A. C. Redfield and V. T. Bowen, Woods Hole Oceanographic Institution, Woods Hole, Massachusetts.

W-570. Centerville, white cedar stump

$2130 \pm 200$

One of a large number of stumps removed from river bed to permit building of wharf at town landing. Depth to sample, $8.3 \mathrm{ft}$ below mean high water. Dates time when cedar swamp was drowned by rising sealevel.

W-589. Centerville, salt marsh, 0.25 ft

Peat samples taken by piston corer from a salt marsh $800 \mathrm{ft} \mathrm{NW}$ of town 
landing. This sample is salt-marsh peat from the surface to $0.25 \mathrm{ft}$ below surface. Surface of marsh is at mean high water.

W-582. Centerville, salt marsh, 5.5 to $6.0 \mathrm{ft} \quad 1640 \pm 240$

Salt peat from depth of 5.5 to $6.0 \mathrm{ft}$.

W-584. Centerville, salt marsh, 6.0 to $6.5 \mathrm{ft}$. $2040 \pm \mathbf{2 4 0}$

Freshwater peat from depth of 6.0 to $6.5 \mathrm{ft}$. Cedar swamp at town landing (W-570) should have been flooded at about the time this sample was deposited.

W-586. Centerville, salt marsh, 14.5 to 15.0 ft. $\quad 5500 \pm 300$

Freshwater peat from depth of 14.5 to $15.0 \mathrm{ft}$ at bottom of salt marsh immediately above gravel and clay basement.

\section{Barnstable series, Massachusetts}

Samples from a contact zone of saltwater peat (above) and freshwater peat (below) at marsh bank midway from Calves Pasture Point and Salten Point, just $\mathbb{W}$ of the Yacht Club, Barnstable Harbor, Barnstable $\left(41^{\circ} 42^{\prime} \mathrm{N}\right.$ Lat, $70^{\circ} 19^{\prime} \mathrm{W}$ Long), Massachusetts. Coll. 1956 and subm. by A. C. Redfield, Woods Hole Oceanographic Institution, Woods Hole, Massachusetts.

W-637. Yacht Club marsh, 27 in.

$190 \pm 150$

Saltwater peat taken by corer at 27 in. depth, 1 in. above contact with freshwater peat. Surface of marsh bank is at mean high water.

W-587. Yacht Club marsh, 28 in.

Wood from contact of fresh- and saltwater peat at $28 \mathrm{in.} \mathrm{depth.} \mathrm{Sample}$ appeared somewhat younger than W-637.

W-639. Yacht Club marsh, 30 in.

$500 \pm 150$

Freshwater peat from 30 in. depth just below W-687.

W-647. Worcester, Massachusetts

Peat exposed during construction of the Massachusetts Turnpike, $0.3 \mathrm{mi}$

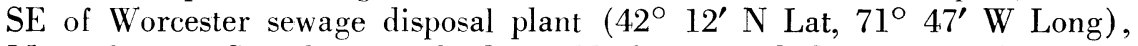
Massachusetts. Sample is tough, dense, black peat underlying $60 \mathrm{ft}$ of gray till and overlying 10 to $12 \mathrm{ft}$ of diatomaceous sand and silt. The peat occurs as a lens dipping NE. The silt and peat are in a protected location SE of a bedrock knoll; the glacier apparently rode over the peat instead of gouging it out. See L-380 (Lamont V), which gave a date of $>30,000 \mathrm{yr}$ for the same peat. Coll. 1957 and subm. by J. H. Hartshorn, U. S. Geological Survey, Boston, Massachusetts.

\section{Great Marsh, Barnstable series, Massachusetts}

A series of borings made in the Great Marsh, Barnstable, at a point ca. $900 \mathrm{ft}$ bearing $56^{\circ} 50^{\prime} \mathrm{N}$ from railroad line at bell-signal pole located $\mathrm{W}$ of its crossing of highway 6 (Proctor's Crossing) $\left(41^{\circ} 43^{\prime} \mathrm{N}\right.$ Lat, $70^{\circ} 21^{\prime} \mathrm{W}$ Long), Massachusetts. Samples, taken with a 2-in. corer, were collected to date significant breaks in the pollen sequence as analyzed (1959) by Patrick Butler. Coll. 1957 and subm. by A. C. Redfield, Woods Hole Oceanographic Institution, Woods Hole, Massachusetts. 
W-677. Great Marsh, no. 2

Peat at depth of $21 \mathrm{in}$.

W-675. Great Marsh, no. 4

$770 \pm 100$

Soft fibrous peat at depth of 33 in.

W-678. Great Marsh, No. 20

$1880 \pm 100$

Very soft fibrous peat at depth of $207 \mathrm{in}$.

W-676. Great Marsh, no. 24

$5480 \pm 120$

Firm fibrous peat at depth of $327 \mathrm{in}$. Clay appears in core at depth of $330 \mathrm{in}$

General comment: dates delimit the duration of the cool moist flora (pine and hemlock) which occurred between 27 and 207 in. They also provide a timedepth scale for the upward growth of the marsh following the rise in sealevel.

\section{Falmouth Kettle series, Massachusetts}

Cores taken from a kettle swamp in the Village of Falmouth Watershed property located $1.6 \mathrm{mi} \mathrm{N}$ of junction of Woods Hole road and route 28 in Falmouth village $\left(41^{\circ} 34^{\prime} 40^{\prime \prime} \mathrm{N}\right.$ Lat, $70^{\circ} 37^{\prime} 20^{\prime \prime} \mathrm{W}$ Long), Falmouth Quadrangle, Massachusetts. Dating the organic matter at the base of the kettle would date the appearance of vegetation after the termination of the last glaciation and thus give a minimum age to the Harbor Hill Moraine, in which the kettle lies. The surface of the swamp is ca. $20 \mathrm{ft}$ above sealevel and is 20 to $30 \mathrm{ft}$ below the lowest sill of the inclosing kettle. Section consists of watery peat, with crumbs of reddish woody material to a depth of $27 \mathrm{ft}$ (from surface of swamp), with a base of stiff silty clay of high organic content. Sand probably underlies the clay, as felt with a $1 / 2$-in. steel probe. Cores of 2 -in. diam. were taken at successive depths from a single hole down to the depth of the silty clay layer, at a point near the center of the hollow. Coll. 1958 and subm. by A. C. Redfield, Woods Hole Oceanographic Institution, Woods Hole, Massachusetts.

\section{W-695. Falmouth $3,28 \mathrm{ft}$ depth $\quad \mathbf{7 6 3 0} \pm 200$ \\ W-697. Falmouth $5,30 \mathrm{ft}$ depth $\quad \mathbf{9 8 7 0} \pm \mathbf{2 5 0}$ \\ W-696. Falmouth 7, $31 \mathrm{ft}$ depth $\quad 9650 \pm 250$ \\ W-710. Martha's Vineyard, Massachusetts $\quad 12,700 \pm 300$}

Dark-gray gyttja from bottom inch of a bog deposit now exposed in upper part of $30-\mathrm{ft}$ sea cliff at Squibnocket Point $\left(41^{\circ} 18^{\prime} \mathrm{N} \mathrm{Lat}, 70^{\circ} 47^{\prime} \mathrm{W}\right.$ Long), Squibnocket Quadrangle, Martha's Vineyard, Massachusetts. Section, from surface downward, consists of: fibrous peat, $8.0 \mathrm{ft}$; gyttja, scattered wood, and stumps, $2.5 \mathrm{ft}$; wood horizon, $1.0 \mathrm{ft}$; gyttja, $10 \mathrm{in}$; fine sand, $1.0 \mathrm{ft}$; compact, gray to pink till to base of cliff. The bog developed in a kettle on the uppermost drift in the Ronkonkoma-Martha's Vineyard-Nantucket moraine; thus the date gives a minimum age for the moraine. Coll. 1957 and subm. by C. A. Kaye, U. S. Geological Survey, Boston, Massachusetts.

W-719. Cape Cod, Massachusetts

$>38,000$

Fragments from an isolated blocky piece of peat in current-bedded, medium-grained gray sand, ca. $30 \mathrm{ft}$ above foot of cliff, $600 \mathrm{ft} \mathrm{N}$ of Highland 
Light, Cape Cod $\left(42^{\circ} 03^{\prime} \mathrm{N}\right.$ Lat, $70^{\circ} 04^{\prime}$ W Long), Massachusetts. Coll. 1958 and subm. by C. A. Kaye, U. S. Geological Survey, Boston, Massachusetts. Comment: the intent of the determination was to establish a maximum age for overlying blue-gray clay. The possibility that the sample was reworked by ice from pre-ice bogs should be considered.

\section{W-726. Plymouth, Massachusetts}

$6190 \pm 200$

Wood from peat layer exposed on shore of Cape Cod Bay, $3.7 \mathrm{mi}$ due $\mathrm{N}$ of Sagamore Bridge over Cape Cod Canal, Plymouth $\left(41^{\circ} 50^{\prime} \mathrm{N}\right.$ Lat, $70^{\circ}$ $32^{\prime}$ W Long), Massachusetts. Section, from top to base, consists of: modern soil, $2 \mathrm{ft}$; stratified sand and gravel, $5 \mathrm{ft}$; peat zone, $5 \mathrm{ft}$. The peat zone is topped by a soil and has two tree horizons. Sample came from the upper of the tree horizons. Coll. 1957 by R. Hecht and C. Shaw; subm. by R. G. Petersen and O. M. Hackett, U. S. Geological Survey, Boston, Massachusetts. Comment: sample was run to see if support would be given to the work of Hyyppä in the Taunton and Bridgewater quadrangles which postulates an interstadial marine submergence between the Tazewell and Cary substages. The date does not support this hypothesis.

\section{W-735. West Lynn, Massachusetts}

$14,250 \pm 250$

Barnacle plates, mostly Balanus crenatus, from Blakely clay pit, Holyoke St., West Lynn $\left(42^{\circ} 27^{\prime} \mathrm{N}\right.$ Lat, $70^{\circ} 57^{\prime} \mathrm{W}$ Long), Lynn Quadrangle, Massachusetts. Marine clays fill valley of Beaver Brook (tributary to Saugus River) to an altitude of ca. $25 \mathrm{ft}$. The clay extends from surface to unknown depth. Marine shells are fairly abundant, and large barnacles particularly so, in upper $25 \mathrm{ft}$. Sample collected from clay that had been dug up by dragline from a depth of 13 to $25 \mathrm{ft}$ below the surface. The clays are probably early postglacial. Coll. 1957 and subm. by C. A. Kaye, U. S. Geological Survey, Boston, Massachusetts.

\section{W-571. Durham, New Hampshire}

$2880 \pm 200$

Wood, from a coarse sand layer, recovered from a pit dug $50 \mathrm{ft} W$ of a perennial tributary stream of Beard's Creek, $0.6 \mathrm{mi} \mathrm{NE}$ of the Durham post office $\left(43^{\circ} 08^{\prime} 33^{\prime \prime} \mathrm{N}\right.$ Lat, $70^{\circ} 55^{\prime} 06^{\prime \prime} \mathrm{W}$ Long), New Hampshire. Sample came from under $5 \mathrm{ft}$ of sand and silt and overlies at least $10 \mathrm{ft}$ of silt and clay. A detailed study of the soils in the section was made by W. H. Lyford. Coll. 1956 and subm. by E. Bradley, U. S. Geological Survey, Durham, New Hampshire, and W. H. Lyford, Soil Conservation Service, U. S. Dept. Agriculture, Washington, D. C. Comment: although the original intent was to date what was thought to be a glacial or immediately postglacial deposit, the sample does give the approximate required time for development of three distinct Low Humic Gley soils.

\section{W-504. Ithaca, New York}

Twigs and bark from lake beds underlying Valley Heads till, exposed in streamcut, south-bank tributary of Sixmile Creek, $50 \mathrm{ft} \mathrm{N}$ of Delaware, Lackawanna and Western RR, $2400 \mathrm{ft} \mathrm{NW}$ of Burns Road overpass, $3 \mathrm{mi} \mathrm{SE}$ of Ithaca $\left(42^{\circ} 27^{\prime} \mathrm{N}\right.$ Lat, $76^{\circ} 29^{\prime} \mathrm{W}$ Long), Tompkins County, New York. Coll. 1956 and subm. by E. H. Muller, Syracuse University, Syracuse, New 
York. Comment: sample dates a pre-Valley Heads proglacial lake. The uncertainty lies in the time interval between the lake deposits and the overlying Valley Heads deposit.

\section{W-506. Dayton, New York}

$1400 \pm 250$

Wood from channel-fill cutting a sequence of silts, till, and sands, exposed in streamcut $1.2 \mathrm{mi}$ ENE of Dayton, $75 \mathrm{ft} \mathrm{N}$ of route 62, Dayton Township ( $42^{\circ} 26^{\prime} \mathrm{N}$ Lat, $78^{\circ} 58^{\prime} \mathrm{W}$ Long), Cattaraugus County, New York. Section consists of two tills separated by silts and sands, and a sand-and-siltfilled channel cutting the above-mentioned units. Both till sheets are believed associated with the Lake Escarpment morainic system. Sample postdates the till deposition. Coll. 1956 and subm. by E. H. Muller, Syracuse University, Syracuse, New York.

\section{W-507. Cheery Tavern, New York $\quad 12,000 \pm 300$}

Wood from base of marly silt, exposed in streamcut of Nichol Creek, $1500 \mathrm{ft}$ NNE of Cheery Tavern, Sardinia Township $\left(42^{\circ} 33^{\prime} \mathrm{N}\right.$ Lat, $78^{\circ} 32^{\prime}$ W Long), Erie County, New York. Silt, abundantly fossiliferous and containing cones and wood fragments, overlies gravel, believed to be outwash, and is overlain by dark-brown silty clay and a lens of fine gravel also containing wood fragments, and by gray-brown silt loam at the surface. The basal gravel marks the final deposition in the formation of the Chaffee outwash plain, considered to be of Valley Heads age. Coll. 1956 and subm. by E. H. Muller, Syracuse University, Syracuse, New York.

\section{W-563. Kings Corners, New York}

Wood from 8-ft section of lake sand in streamcut, south-bank tributary of Great Gully ca. $750 \mathrm{ft} \mathrm{S}$ of confluence with Great Gully Creek, 1.4 mi NW of Kings Corners, $1.3 \mathrm{mi} \mathrm{S}$ of School No. 4, Union Springs Quadrangle $\left(42^{\circ}\right.$ $41^{\prime} \mathrm{N}$ Lat, $76^{\circ} 38^{\prime} \mathrm{W}$ Long), Cayuga County, New York. Wood fragments come from $2 \mathrm{ft}$ above basal contact of enclosing lake sand with underlying till. Sand is overlain by another till. Coll. 1956 and subm. by R. C. Shumaker and E. H. Muller, Syracuse University, Syracuse, New York. Comment: sample dates a Wisconsin intraglacial interval during which the ice border stood at least $40 \mathrm{mi} \mathrm{N}$ of the Valley Heads end moraine.

\section{Nassau County series, New York}

Shells from two outcrops in northern Nassau County and from two wells in southwestern Nassau County, New York.

W-610. Woodmere, well no. N4257

Shells bailed from well at depth of $45 \mathrm{ft}(20 \mathrm{ft}$ below sealevel), $268 \mathrm{ft} \mathrm{N}$ of Central Ave. and $152 \mathrm{ft} W$ of Irving Place, Woodmere $\left(40^{\circ} 38^{\prime} \mathrm{N}\right.$ Lat, $73^{\circ} 43^{\prime}$ W Long), Nassau County, New York. Shells came from a fine sand, silt, and clay layer under $35 \mathrm{ft}$ of outwash. At $90 \mathrm{ft}$ depth, driller hit the Gardiners clay. Coll. 1954 and subm. by N. M. Perlmutter, U. S. Geological Survey, Mineola, New York.

W-612. West Hempstead, well no. $\mathbf{N} 4118$

Shells from core taken at depth of 82 to $84 \mathrm{ft}(27$ to $29 \mathrm{ft}$ below sealevel) on Birch St., West Hempstead $\left(40^{\circ} 41^{\prime} \mathrm{N}\right.$ Lat, $73^{\circ} 39^{\prime} \mathrm{W}$ Long), Nassau 
County, New York. Section consists of outwash from surface to $82 \mathrm{ft}$ depth, silt and clay from 82 to $92 \mathrm{ft}$, and sand and gravel to base at $212 \mathrm{ft}$. Coll. 1953 and subm. by N. M. Perlmutter, U. S. Geological Survey, Mineola, New York.

\section{W-611. Port Washington}

Oyster shells from marine clay in streambed at western boundary of Nassau Knolls Cemetery, Port Washington ( $40^{\circ} 49^{\prime}$ N Lat, $73^{\circ} 4 \mathrm{l}^{\prime} \mathrm{W}$ Long), Nassau County, New York. From large masses of marine clay that appear to be incorporated in till sheet. Coll. 1956 and subm. by W. V. Swarzenski, U. S. Geological Survey, Mineola, New York.

\section{W-613. Glen Cove}

$>38,000$

Shell fragments, washed from greenish-brown clay on $\mathrm{E}$ shore of Hempstead harbor $1000 \mathrm{ft} \mathrm{S}$ of A. M. Loew estate, Glen Cove $\left(40^{\circ} 52^{\prime} \mathrm{N}\right.$ Lat, $73^{\circ}$ 39' W Long), Nassau County, New York. From Pleistocene marine deposit underlying $30 \mathrm{ft}$ of till and outwash. Sample layer overlies Cretaceous bedrock. Coll. 1956 and subm. by W. V. Swarzenski, U. S. Geological Survey, Mineola, New York.

\section{W-716. Port Washington, New York}

$\mathbf{5 3 1 0} \pm \mathbf{2 4 0}$

Plant debris, partially lignitized, from peat deposit on Flower Hill Estates, Port Washington $\left(40^{\circ} 49^{\prime} \mathrm{N}\right.$ Lat, $73^{\circ} 4 \mathrm{l}^{\prime} \mathrm{W}$ Long), Nassau County, New York. From base of 6 - $\mathrm{ft}$ layer of peat overlying 20 to $25 \mathrm{ft}$ of till, thus giving a minimum age to the Harbor Hill moraine. Coll. 1957 and subm. by W. V. Swarzenski, U. S. Geological Survey, Mineola, New York.

\section{W-720. Norwich, New York}

$9800 \pm 300$

Peat from lens within clay in an area of drift of Binghamton age exposed in pipeline trench on $\mathrm{S}$ side of prominent kame, $1.25 \mathrm{mi} \mathrm{NE}$ of Norwich $\left(42^{\circ} 32^{\prime} \mathrm{N}\right.$ Lat, $75^{\circ} 30^{\prime} \mathrm{W}$ Long), New York. Coll. 1955 and subm. by J. H. Moss, Franklin and Marshall College, Lancaster, Pennsylvania.

\section{W-721. Little Conewango Creek, New York}

Wood fragments from streamcut of the Little Conewango Creek, $1 \mathrm{mi} \mathrm{W}$ of Steamburg, where creek goes through culvert under Erie RR tracks $\left(42^{\circ}\right.$ $07^{\prime} \mathrm{N}$ Lat, $78^{\circ} 55^{\prime} \mathrm{W}$ Long), Randolph Quadrangle, Cattaraugus County, New York. From gray wood-bearing silt under gravelly sandy loam. Coll. 1957 and subm. by E. H. Muller, Syracuse University, Syracuse, New York. Comment: stratigraphy is probably disturbed by construction work.

\section{W-722. Cattaraugus, New York}

Wood (white birch) from streambank cut, south-bank tributary of $\mathrm{S}$ branch of Cattaraugus Creek, $0.1 \mathrm{mi} \mathrm{E}$ of $\mathrm{SE}$ corner of Cattaraugus village $\left(42^{\circ} 20^{\prime} \mathrm{N}\right.$ Lat, $78^{\circ} 52^{\prime} \mathrm{W}$ Long), Cattaraugus Quadrangle, Cattaraugus County, New York. From layer of fine gray sand and peat overlain by cobbly to bouldery gravel. Coll. 1957 and subm. by E. H. Muller, Syracuse University, Syracuse, New York.
W-813. Lewiston, New York
$8520 \pm 300$
W-861. Lewiston, New York, rerun
$12,660 \pm 400$

Picea mariana (id. by D. Bierhorst) from laminated silt and clay de- 
posits of Lake Iroquois, unearthed in excavation at Lewiston in connection with the Niagara Power Project of the New York State Power Authority, in spoil area in SE Lewiston $\left(43^{\circ} 10^{\prime} \mathrm{N}\right.$ Lat, $79^{\circ} 02^{\prime} \mathrm{W}$ Long), New York. From $340 \mathrm{ft}$ altitude in gray silty clay, overlying till and underlying brown silty clay. The first run (W-813), was made at a time when the counter was operating erratically. A second run (W-861) was made of a newly prepared sample from the same piece of wood. The two dates have such a large spread that an entirely different log was recently obtained for processing and dating. Date has an important bearing on the age of Niagara Falls. Coll. 1958 by C. P. Benziger, of Uhl, Hall, and Rich, Lewiston, New York; subm. by E. H. Muller, Syracuse University, Syracuse, New York.

W-866. Gowanda, New York

Compressed wood from streamcut $1.2 \mathrm{mi} \mathrm{N}$ of Gowanda at State Hospital, where Clear Creek crosses U. S. highway $62\left(42^{\circ} 30^{\prime} \mathrm{N}\right.$ Lat, $78^{\circ} 56^{\prime} \mathrm{W}$ Long), Cattaraugus Quadrangle, Erie County, New York. From ca. $5 \mathrm{ft}$ above stream level in gravel overlying red till and underlying several tills interbedded with sand and gravel. Coll. 1959 by E. H. Muller and M. Rubin.

W-877. New Shoreham, Block Island, Rhode Island 10,500 \pm 210

Core of organic mud from bog section, $5.9 \mathrm{~m}$ deep, at New Shoreham, Block Island ( $41^{\circ} 10^{\prime} 20^{\prime \prime} \mathrm{N}$ Lat, $71^{\circ} 34^{\prime} 30^{\prime \prime} \mathrm{W}$ Long), Rhode Island. Sample consisted of the bottoms of two closely spaced holes, both from an organic mud between two clay layers. Depths sampled were 4.80 to $5.05 \mathrm{~m}$ and 5.12 to $5.27 \mathrm{~m}$. Pollen stratigraphy being studied by E. B. Leopold, U. S. Geological Survey, Denver, Colorado. Coll. 1956 by E. S. Deevey and J. G. Ogden III, Yale University, New Haven, Connecticut; subm. by C. A. Kaye, U. S. Geological Survey, Boston, Massachusetts.

W-817. Washington, D. C.

$>\mathbf{3 8 , 0 0 0}$

Wood from bog deposit unearthed during excavation for relocation of Wheeler Road, $1500 \mathrm{ft} \mathrm{E}$ of SE District of Columbia boundary line $\left(38^{\circ} 50^{\prime}\right.$ N Lat, $76^{\circ} 59^{\prime} \mathrm{W}$ Long), Prince Georges County, Maryland. From a black organic clay containing vivianite crystals, overlain by $15 \mathrm{ft}$ of silt and $15 \mathrm{ft}$ of gravel at the surface. Altitude $185 \mathrm{ft}$. Coll. 1958 by J. R. Rubin and M. Rubin.

\section{B. Central United States}

W-524. Farmdale, Illinois

$18,460 \pm 500$

Wood from basal $1 \mathrm{ft}$ of Shelbyville (Tazewell) till in railroad cut $.625 \mathrm{mi}$ $\mathrm{E}$ of Farmdale, NW $1 / 4$ sec. $31, \mathrm{~T} 26 \mathrm{~N}$, R $3 \mathrm{~W}\left(40^{\circ} 40^{\prime} \mathrm{N}\right.$ Lat, $89^{\circ} 30^{\prime} \mathrm{W}$ Long), Tazewell County, Illinois. The cut is ca. $1 \mathrm{mi} \mathrm{SW}$ of the classic Farm Creek section and records the same sequence. Coll. 1956 and subm. by M. M. Leighton and J. Brophy, Illinois State Geological Survey, Urbana.

W-526. Virginia, Illinois

$29,000 \pm 1200$

Wood from dug well on the R. E. Jokisch farm, $2.5 \mathrm{mi} \mathrm{S}$ of Virginia, in NE $1 / 4$ NE $1 / 4$ sec. 22 , T $17 \mathrm{~N}$, R $10 \mathrm{~W}\left(39^{\circ} 55^{\prime} \mathrm{N}\right.$ Lat, $90^{\circ} 12^{\prime} \mathrm{W}$ Long), Cass County, Illinois. From $20 \mathrm{ft}$ depth in rusty-gray silt, resembling Farmdale loess. Well bottom is at $39 \mathrm{ft}, 3 \mathrm{ft}$ into blue pebbly hardpan, probably Illino- 
ian-age drift. Coll. 1956, interpreted, and subm. by M. M. Leighton, Illinois State Geological Survey, Urbana.

W-642. Princeton, Illinois

$26,200 \pm 800$

Wood from upper $1 \mathrm{ft}$ of Farmdale-age loess in $\mathrm{E}$ valley wall of East Bureau Creek, $5 \mathrm{mi}$ E, $1 \mathrm{mi} N$ of Princeton ("A" section), in $\mathrm{SE} 1 / 4 \mathrm{SW} 1 / 4$ $\mathrm{SE} 1 / 4$ sec. 5 , T $16 \mathrm{~N}$, R $10 \mathrm{E}\left(41^{\circ} 24^{\prime} \mathrm{N}\right.$ Lat, $89^{\circ} 28^{\prime} \mathrm{W}$ Long), Bureau County, Illinois. Section similar to that described in W-333 (USGS IV), which also gave a Farmdale date of 25,700 \pm 800 . Coll. 1957 and subm. by M. M. Leighton, Illinois State Geological Survey, Urbana.

\section{W-725. Evanston, Illinois}

$4030 \pm 150$

Log from beach gravel at 800 Hinman Ave., SW1/4 NE $1 / 4$ sec. 19, T 41 N, R $14 \mathrm{E}\left(42^{\circ} 03^{\prime} \mathrm{N}\right.$ Lat, $87^{\circ} 42^{\prime} \mathrm{W}$ Long $)$, Evanston, Illinois. Sample came from deposits of the Graceland Spit at the Lake Toleston level, 15 to $20 \mathrm{ft}$ below the present surface, and $1 \mathrm{ft}$ above gray, slightly calcareous till. Coll. 1958 and subm. by L. H. Nobles. Northwestern University, Evanston, Illinois.

\section{Madison County series, Illinois}

Snail shells from thick loess section above Illinoian-age till and Sangaman-age soil. Section, from top to base, consists of: 9. loess, thick-bedded to massive, gray-tan, calcareous, fossiliferous, $15 \mathrm{ft}$; 8. loess, massive, calcareous, fossiliferous, prominent columnar jointing, $11 \mathrm{ft} ; 7$. loess, massive, structureless, calcareous and fossiliferous, $12 \mathrm{ft} ; 6$. loess, massive, pinkish tan, calcareous, fossiliferous, $10 \mathrm{ft}$; 5 . sand, fine calcareous, $1.5 \mathrm{ft} ; 4$. loess, weakly calcareous to noncalcareous, pink-tan humic streaks in lower $\mathrm{ft}$, fossiliferous in upper $2 / 3,8.5 \mathrm{ft}$; 3 . soil profile loess, massive, leached in upper $7 \mathrm{ft}$, truncates Sangamon soil, $7 \mathrm{ft}$; 1. Sangamon-age soil, with typical soil horizons, grading to calcareous Illinoian-age till, $11.8 \mathrm{ft}$. Section measured, samples coll. 1958 by J. C. Frye, H. B. Willman, Illinois State Geological Survey, Urbana, and A. B. Leonard, University of Kansas, Lawrence; subm. by Frye. General comment: a more complete section description and discussion of classification appears in Frye and Willman (1960).

W-729. Pleasant Grove school, Illinois

Shells from unit 4 above, exposed at Pleasant Grove school, center of $\mathrm{SE} 1 / 4$ sec. 20 , T $3 \mathrm{~N}, \mathrm{R} 8 \mathrm{~W}\left(38^{\circ} 42^{\prime} \mathrm{N}\right.$ Lat, $90^{\circ} 0 \mathrm{l}^{\prime} \mathrm{W}$ Long $)$, Madison County, Illinois.

\section{W-730. Burdick Branch, Illinois}

$17,100 \pm 300$

Shells from unit 9 above, exposed at Burdick Branch, $3.5 \mathrm{mi} \mathrm{N}$ of W-729 locality, in sec. 4, T $3 \mathrm{~N}, \mathrm{R} 8 \mathrm{~W}\left(38^{\circ} 44^{\prime} \mathrm{N}\right.$ Lat, $90^{\circ} 00^{\prime} \mathrm{W}$ Long $)$, Madison County, Illinois.

\section{W-868. Peters loess section, Illinois}

$\mathbf{2 7 , 5 0 0} \pm \mathbf{9 0 0}$

Shells from unit 4 above, from Peters loess section, $.25 \mathrm{mi}$ N of W-730 locality in center of W line sec. 4 , T $3 \mathrm{~N}, \mathrm{R} 8 \mathrm{~W}\left(38^{\circ} 44^{\prime} \mathrm{N}\right.$ Lat, $90^{\circ} 00^{\prime} \mathrm{W}$ Long), Madison County, Illinois. The Peters loess section differs from the Pleasant Grove and Burdick Branch sections in that it does not contain units 2 and 3. Samples collected in 1959 during several visits to the locality, in an effort to obtain sufficient material for an analysis. A small admixture of the 
younger fossil zone shells to the older, giving the intermediate date, is a distinct possibility, according to the collectors.

\section{W-745. Fulton County, Illinois}

Stems and twigs from a bog deposit exposed at $\mathbb{W}$ side of Illinois River valley in SE corner of NW $1 / 4$ sec. 33 , T $4 \mathrm{~N}$, R $3 \mathrm{E}\left(40^{\circ} 24^{\prime} \mathrm{N}\right.$ Lat, $90^{\circ} 07^{\prime} \mathrm{W}$ Long), Fulton County, Illinois. Loess mantles the valley wall and the surface of the terrace (mapped as Tazewell-age slackwater terrace by Wanless, 1957) and is richly fossiliferous. Below the loess, a deepened road ditch exposes the bog deposit with the wood. The matrix is noncalcareous, but is immediately overlain by calcareous, highly fossiliferous loess. Coll. 1958 by J. C. Frye, H. B. Willman, Illinois State Geological Survey, Urbana, and A. B. Leonard, University of Kansas, Lawrence; subm. by Frye.

\section{W-870. Enion North, Illinois \\ $20,300 \pm 400$}

Shells from Enion North loess section, just $\mathrm{W}$ center sec. $28, \mathrm{~T} 4 \mathrm{~N}$, R $3 \mathrm{E}\left(40^{\circ} 25^{\prime} \mathrm{N}\right.$ Lat, $90^{\circ} 07^{\prime} \mathrm{W}$ Long $)$, Fulton County, Illinois. Sample from uppermost faunal zone in the Central Illinois Valley, from the top of the loess sequence that rests on the bog from which W-745 wood, $23,500 \pm 400$ (this list) was taken, though not from the same section. The 70-gram shell sample was concentrated from ca. .75 ton of loess. Coll. 1959 by A. B. Leonard, University of Kansas, Lawrence, H. B. Willman, and J. C. Frye, Illinois State Geological Survey, Urbana; subm. by Frye. Comment: the loess is immediately pre-Shelbyville or perhaps Shelbyville maximum in age.

\section{W-823. Hutchins Creek, Illinois}

$4840 \pm 300$

Wood from terrace segment on Hutchins Creek, in NW1/4 SW1/4 SW $1 / 4$ sec. 25 , T $11 \mathrm{~S}$, R $3 \mathrm{~W}\left(37^{\circ} 32^{\prime} \mathrm{N}\right.$ Lat, $89^{\circ} 23^{\prime} \mathrm{W}$ Long), Union County, Illinois. Taken from $\log$ at $24 \mathrm{ft}$ depth below the terrace surface in silt containing layers of well-preserved leaves as well as two large logs. Coll. 1957 by S. E. Harris, Jr., Southern Illinois University, Carbondale; subm. by H. B. Willman, Illinois State Geological Survey, Urbana.

\section{W-826. Jerseyville, Illinois}

Wood (spruce) found in Illinoian-age till at Jerseyville $\left(39^{\circ} 08^{\prime} \mathrm{N}\right.$ Lat, $90^{\circ} 18^{\prime} \mathrm{W}$ Long), Jersey County, Illinois. From depth of $27 \mathrm{ft}, 8 \mathrm{ft}$ above bedrock. Coll. 1959 and subm. by D. Bloss, Southern Illinois University, Carbondale.

\section{Buckheart strip mine series, Illinois}

Wood from Farmdale-age peat exposed in an old highwall of the United Electric Buckheart strip mine, in SE $1 / 4$ sec. $13, \mathrm{~T} 6 \mathrm{~N}, \mathrm{R} 4 \mathrm{E}\left(40^{\circ} 31^{\prime} \mathrm{N}\right.$ Lat, $90^{\circ} 00^{\prime} \mathrm{W}$ Long), Manito Quadrangle, Fulton County, Illinois. Section, from top to base, consists of: Peorian loess, calcareous at base, $10 \mathrm{ft}$; Farmdale-age peaty silt, $6 \mathrm{ft}$; colluvium, $4 \mathrm{ft}$; Illinoian-age till, leached, $5 \mathrm{ft}$ exposed. Coll. 1957 by J. A. Brophy; subm. by M. M. Leighton, Illinois State Geological Survey, Urbana.

W-849. Farmdale-age wood, no. $72557-2$

Wood from upper $1 \mathrm{ft}$ of Farmdale-age peat.

$23,700 \pm 550$ 
W-853. Farmdale-age wood, no. 72557-3

Wood from $2 \mathrm{ft}$ below top of Farmdale-age peat.

\section{W-867. Shawneetown, Illinois}

$22,200 \pm 450$

Shells from loess exposed $1 \mathrm{mi}$ SE of bridge across the Ohio River near Shawneetown (37 $42^{\prime} \mathrm{N}$ Lat, $88^{\circ} 07^{\prime} \mathrm{W}$ Long), Gallatin County, Illinois, just below mouth of Wabash River. Section, from top to base, consists of: loess, calcareous, gray, $20 \mathrm{ft}$; loess, calcareous, gray, fossiliferous (this sample) with $\mathrm{CaCO}_{3}$ nodules, $5 \mathrm{ft}$; loess, noncalcareous to weakly calcareous, dark gray to light brown, nonfossiliferous, basal part pinkish, $6 \mathrm{ft}$; soil, red to red-brown clay and silt, manganese pellets, probably Sangamon soil, $4 \mathrm{ft}$; silt, yellow, tan and red brown, noncalcareous, nonfossiliferous, rests on sandstone bedrock of Pennsylvanian age, $6 \mathrm{ft}$. Coll. 1959 by A. B. Leonard, University of Kansas, Lawrence, H. B. Willman, and J. C. Frye, Illinois State Geological Survey, Urbana; subm. by Frye.

W-869. Alexander County, Illinois

$\mathbf{3 7 , 0 0 0} \pm 1500$

Shells from Gale loess section in center sec. 33 , T $14 \mathrm{~S}, \mathrm{R} 3 \mathrm{~W}\left(37^{\circ} 1^{\prime}\right.$ $\mathrm{N}$ Lat, $89^{\circ} 26^{\prime} \mathrm{W}$ Long), Alexander County, Illinois. Section is comparable to that at Pleasant Grove, W-729 (this list), consisting of $52 \mathrm{ft}$ of loess overlying a Sangamon-age soil. Sample taken $39 \mathrm{ft}$ depth in a fossiliferous loess (Roxana loess of Frye and Willman). Coll. 1959 by A. B. Leonard, University of Kansas, Lawrence, H. B. Willman, and J. C. Frye. Comment: for description and significance of section, see Frye and Willman (1960).

W-871. Wedron quarry, La Salle County, Illinois $\quad \mathbf{2 6 , 8 0 0} \pm \mathbf{7 0 0}$

Wood from Farmdale silt near base of section exposed in $\mathrm{SW}$ end of Wedron Silica Company quarry in vertical face, in SE1/4 SE1/4 SW1/4 sec. 9, T 34 N, R 4 E (41 $26^{\prime}$ N Lat, 88 $47^{\prime}$ W Long), La Salle County, Illinois. Section, from top to base, consists of: loess, $6 \mathrm{ft}$; till, $5 \mathrm{ft}$; till, pink (Bloomington till), $15 \mathrm{ft}$; till, gray and tan, $3 \mathrm{ft}$; sand and gravel, 10 to $20 \mathrm{ft}$; silt, clayey, pink to red to red brown (sample W-79, 24,000 \pm 700 (USGS I) came from here), 10 to $20 \mathrm{ft}$; silt with some clay and fine sand, gray blue to dark gray or black, calcareous, numerous twigs and wood fragments in upper 1/3 (sample from here), $25 \mathrm{ft}$; St. Peter sandstone to base. Coll. 1959 by A. B. Leonard, University of Kansas, Lawrence, H. B. Willman, and J. C. Frye, Illinois State Geological Survey, Urbana; subm. by Frye.

\section{W-577. Parke County, Indiana}

$\mathbf{2 0 , 5 0 0} \pm \mathbf{8 0 0}$

Wood from peaty, mollusk-rich silt at the base of till which overlies a paleosol. Section is $3 \mathrm{mi} \mathrm{N}$ (inside) the Wisconsin-age till boundary, in the

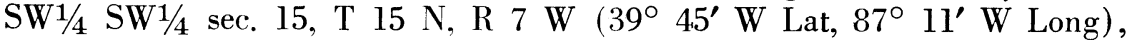
Parke County, Indiana. Coll. 1956 and subm. by W. J. Wayne and H. C. Hutchinson, Indiana State Geological Survey, Bloomington.

W-578. Trader's Point, Indiana

Wood fragments from fossiliferous silt in a bluff $1 \mathrm{mi} W$ of Trader's Point, in SE $1 / 4$ SE $1 / 4$ sec. 29, T $17 \mathrm{~N}, \mathrm{R} 2 \mathrm{E}\left(39^{\circ} 53^{\prime} \mathrm{N}\right.$ Lat, $86^{\circ} 16^{\prime} \mathrm{W}$ Long), Marion County, Indiana. The silt separates two calcareous tills. No visible break occurs in the upper till, and the silt lies directly on completely un- 
weathered till. Section described in detail by Thornbury and Wayne (1953, Stop 13, Indiana portion). Coll. 1954 and subm. by W. J. Wayne, Indiana State Geological Survey, Bloomington. Comment: since both tills are considered Wisconsin in age, the date adds to the evidence of an "early Wisconsin", older than Farmdale.

W-579. Marion County, Indiana

$\mathbf{2 0 , 8 0 0} \pm \mathbf{8 0 0}$

Logs from base of till thought to be of Wisconsin age, in the SW1/4 SE $1 / 4$ sec. $28, \mathrm{~T} 17 \mathrm{~N}, \mathrm{R} 2 \mathrm{E}\left(39^{\circ} 53^{\prime} \mathrm{N}\right.$ Lat, $86^{\circ} 15^{\prime} \mathrm{W}$ Long $)$, Marion County, Indiana. Till contains inclusions of noncalcareous clay from a paleosol. Coll. 1956 and subm. by W. J. Wayne and P. W. Harrison, Indiana State Geological Survey, Urbana.

W-595. Clayton, Indiana

$\mathbf{2 2 , 3 0 0} \pm \mathbf{8 0 0}$

Wood from base of section exposed on SW bank of West Fork White Lick Creek, 2 mi NE of Clayton, in NE1/4 NW1/4 sec. 26, T 15 N, R 1 W $\left(39^{\circ} 42^{\prime} \mathrm{N}\right.$ Lat, $86^{\circ} 30^{\prime} \mathrm{W}$ Long), Hendricks County, Indiana. Section described by Thornbury and Wayne (1957, Stop 1), sample from Unit 1. Essentially, the section consists of two calcareous Wisconsin-age tills separated by a fossiliferous silt. Sample came from the lower till (which is $8 \mathrm{ft}$ thick with base not exposed); taken $6 \mathrm{ft}$ from top of till. Coll. 1957 and subm. by H. B. Willman, Illinois State Geological Survey, Urbana.

\section{Trafalgar series, Indiana}

Three wood samples from a streamcut (Buckhart Creek) ca. $500 \mathrm{ft} \mathrm{N}$ of Indiana State Road 252, $1.5 \mathrm{mi} \mathrm{E}$ of Trafalgar, in $\mathrm{SE}^{1 / 4} \mathrm{NE} 1 / 4 \sec 8$, $\mathrm{T} 11 \mathrm{~N}, \mathrm{R} 4 \mathrm{E}\left(39^{\circ} 25^{\prime} \mathrm{N}\right.$ Lat, $86^{\circ} 08^{\prime} \mathrm{W}$ Long $)$, Johnson County, Indiana. The section has been measured and fossil assemblages determined by $\mathbb{W}$. J. Wayne, Indiana State Geological Survey. Section description appears in Thornbury and Wayne (1957, Stop 11). In brief, the section consists of two Wisconsin tills separated by a fossiliferous silt; the whole resting on a noncalcareous till. Samples dated come from the silt and from the till unit just above the basal till. Unit numbers refer to units in Guidebook (Thornbury and Wayne, 1957), decreasing with depth.

W-598. Stop 11, Unit 5

$20,100 \pm 800$

Wood from brownish-gray calcareous silt. This unit underlies calcareous till. Coll. 1957 and subm. by J. Brophy, W. J. Wayne, Indiana State Geological Survey, Bloomington, and M. Rubin.

W-597. Stop 11, Unit 4

$20,300 \pm 800$

Wood from brownish-yellow, calcareous silt. Coll. 1957 and subm. by T. N. V. Karlstrom and M. Rubin.

W-580. Stop 11, Unit 2

$20,900 \pm 800$

Wood from base of dark grayish-brown, silty and sandy till. This till overlies an orange-brown to bright bluish-gray silty, sandy and stony, noncalcareous till. Parts of the lower till are incorporated as contorted masses in the Unit 2 till above, and some wood fragments occur in both tills. Coll. 1956 and subm. by W. J. Wayne, Indiana State Geological Survey, Bloomington. 
W-615. Warrick County, Indiana

$19,940 \pm 300$

Wood from ditch at hase of partially removed hill NE of Warrick Smelter of Aluminum Company of America, NE $1 / 4$ SE $1 / 4$ sec. 8 , T $7 \mathrm{~S}, \mathrm{R} 8 \mathrm{~W}\left(37^{\circ}\right.$ $55^{\prime} \mathrm{N}$ Lat, $87^{\circ} 21^{\prime} \mathrm{W}$ Long), Yankeetown Quadrangle, Warrick County, Indiana. Sample taken from gray clayey silt which represents lacustrine deposits in ponded stream tributary to nearby Ohio River at the time the Ohio valley was being actively alluviated by valley train of Tazewell age. The lacustrine sediments overlie loess of Farmdale age and grade upslope into loess deposits on hill marginal to ponded tributary, without observable stratigraphic break, indicating contemporaneous deposition. Coll. 1957 and subm. by L. L. Ray, U. S. Geological Survey, Washington, D. C.

W-663. Mansfield (north), Indiana

$23,300 \pm 600$

Wood from new roadcut along $\mathrm{E}$ side of Indiana highway $59,2.5 \mathrm{mi} \mathrm{N}$ of Mansfield, in SW $1 / 4$ NW $1 / 4 \mathrm{SW}^{1} / 4$ sec. 29 , T $15 \mathrm{~N}$, R $6 \mathrm{~W}\left(39^{\circ} 43^{\prime} \mathrm{N}\right.$ Lat, $87^{\circ} 06^{\prime}$ W Long), Parke County, Indiana. Section described in Thornbury and Wayne (1957, Stop 5). Wood was embedded in peat and dark-gray humic clay, directly beneath $8 \mathrm{ft}$ of till (calcareous in lower part) and loess, and at the top of a paleosol. Sample taken $600 \mathrm{ft} \mathrm{N}$ from margin of maximum advance of Wisconsin-age drift at this location, dates time when the ice reached its most extensive position. Coll. 1957 by W. J. Wayne and H. C. Hutchison; subm. by C. E. Weir, Indiana State Geological Survey, Bloomington, through H. C. Wagner.

\section{W-666. Farmersburg, Indiana $\quad 4040+250$}

Wood from bank of Prairie Creek, $5 \mathrm{mi} \mathrm{NW}$ of Farmersburg, in NE $1 / 4$ $\mathrm{SE} 1 / 4$ sec. 7 , T $10 \mathrm{~N}, \mathrm{R} 9 \mathrm{~W}\left(39^{\circ} 20^{\prime} \mathrm{N}\right.$ Lat, $87^{\circ} 26^{\prime} \mathrm{W}$ Long), Vigo County, Indiana. Embedded at $5 \mathrm{ft}$ depth in sediments lying beneath the floodplain of Prairie Creek. Noncalcareous gravel underlies the wood-bearing silt zone; clayey silt overlies the zone. Prairie Creek was ponded during Wisconsin glacial age hy outwash in the Wabash Valley. This wood was thought to have heen buried at that time or to represent a post-Wisconsin-age cut-and-fill. Date suports the latter interpretation. Coll. 1957 by W. J. Wayne and C. E. Wier, Indiana State Geological Survey, Bloomington; subm. by Wier through H. C. Wagner.

\section{W-668. Vigo County, Indiana $\quad 21,400 \pm 650$}

Wood (conifer) exposed in $\mathrm{S}$ bank of a creek in NW $1 / 4$ NE $1 / 4$ sec. 9, T $12 \mathrm{~N}, \mathrm{R} 10 \mathrm{~W}\left(39^{\circ} 29^{\prime} \mathrm{N}\right.$ Lat, $87^{\circ} 30^{\prime} \mathrm{W}$ Long), Vigo County, Indiana. Taken from peaty soil in a shear-zone stringer at base of Wisconsin-age till, overlying till of presumed Illinoian age. Location is in the Shelbyville moraine on the $\mathrm{W}$ side of the interlobate re-entrant between Illinois and Indiana lobes, (a. $1 \mathrm{mi} \mathrm{N}$ (inside) the Wisconsin-age drift houndary. Coll. 1956 by W. J. Wayne and S. A. Friedman, Indiana State Ceological Survey, Bloomington; subm. by C. E. Wier, through H. C. Wagner.

W-669. Mansfield (west), Indiana

Wood from creek bluff $1000 \mathrm{ft} W$ of road, $2.5 \mathrm{mi} W$ of Mansfield, in SE $1 / 4$ SE $1 / 4$ sec. 2, T 14 N, R 7 W (39 $47^{\prime}$ N Lat, $87^{\circ} 09^{\prime}$ W Long), Parke 
County, Indiana. Recovered from peaty lenses at top of a paleosol beneath calcareous Wisconsin-age till. The paleosol was developed on till of presumed Illinoian age. Sample is from location $1 \mathrm{mi} \mathrm{S}$ of previously recognized and published position of Wisconsin glacial boundary. Coll. 1957 by W. J. Wayne, Indiana State Geological Survey, Bloomington; subm. by C. E. Weir through H. C. Wagner.

W-680. Mt. Vernon, Indiana

$640 \pm 200$

Wood fragments from near base of artificial ditch, $200 \mathrm{ft} W$ of bridge on road bounding $\mathrm{E}$ side of sec. $21, \mathrm{~T} 6 \mathrm{~S}, \mathrm{R} 12 \mathrm{~W}\left(37^{\circ} 58^{\prime} \mathrm{N}\right.$ Lat, $87^{\circ} 47^{\prime} \mathrm{W}$ Long), $8 \mathrm{mi} \mathrm{NE}$ of Mt.Vernon, Uniontown Quadrangle, Indiana. The ditch is cut to bedrock along a low hill. The bedrock is overlain by $10 \mathrm{ft}$ of gray lacustrine silt believed to be correlative with Shelbyville (Tazewell-age) moraine. Here, however, the woody material most likely belongs to old creek bottom deposits, exposed during construction of the ditch. Coll. 1957 and subm. by L. L. Ray, U. S. Geological Survey, Washington, D. C.

\section{W-814. Zionsville, Indiana}

Wood fragments from section exposed in streamcut in NE1/4 SE $1 / 4$ SE $1 / 4$ sec. 29, T 17 N, R 2 E ( $39^{\circ} 53^{\prime}$ N Lat, $86^{\circ} 19^{\prime} \mathrm{W}$ Long), Zionsville Quadrangle, Indiana. From till immediately above contact of the till with underlying silt. This till is overlain by a sequence of gravel and till layers; the silt is underlain by a very dense gray till. Coll. 1958 by H. Pee and W. Harrison, Indiana State Geological Survey, Bloomington; subm. by Harrison.

\section{W-832. Posey County, Indiana}

$7030 \pm 260$

Wood from blue-gray lacustrine silt in creek bed, $150 \mathrm{ft} \mathrm{S}$ of bridge across Big Creek, in SE $1 / 4$ SW $1 / 4$ sec. 34, T 4 S, R 12 W (38 $08^{\prime}$ N Lat, $87^{\circ} 45^{\prime} \mathrm{W}$ Long), Haubstadt Quadrangle, Posey County, Indiana. Section, from top to base, consists of: gray, fine sandy silt, noncalcareous, 8 to $12 \mathrm{ft}$; silt, oxidized, with topping of fine pebbles and sand cemented together, $1 \mathrm{ft}$; blue-gray, noncalcareous silt (sampled), $2 \mathrm{ft}$ exposed. Coll. 1958 and subm. by L. L. Ray, U. S. Geological Survey, Washington, D. C. Comment: these lacustrine beds were originally correlated with Tazewell deposits, but the date precludes this.

\section{Scranton no. 1 forest bed series, Iowa}

Wood from spectacular buried forest bed uncovered during a recent relocation of U. S. highway 30 , ca. $4 \mathrm{mi} \mathrm{E}$ of Scranton. The roadcut section is on the $E$ valley slope of the Raccoon River, in the SW $1 / 4$ sec. 33, T 84 N, $\mathrm{R} 31 \mathrm{~W}\left(42^{\circ} 02^{\prime} \mathrm{N}\right.$ Lat, $94^{\circ} 28^{\prime} \mathrm{W}$ Long $)$, Greene County, Iowa. Three samples coll. 1956 and subm. by R. V. Ruhe, U. S. Dept. Agriculture, State College, New Mexico, and W. H. Scholtes, Iowa State University, Ames. An additional sample from the base of the lower till coll. as a check on the first run. W-640 coll. 1957 and subm. by M. M. Leighton, A. C. Trowbridge, C. Brown, L. L. Ray, and M. Rubin. For a more complete section description, see Ruhe, Rubin, and Scholtes (1957). Section, from top to base, consists of: Cary-age till, $18 \mathrm{ft}$; silt (forest hed in top $11 \mathrm{ft}$ of this unit), $18 \mathrm{ft}$; till, $13 \mathrm{ft}$. 
W-512. Scranton no. 1 , top of forest bed $14,470 \pm 400$

Wood from forest bed just below contact of Cary-age till. Trunks of trees rooted in this zone were bent over toward the south.

W-513. Scranton no. 1 , base of forest bed $13,820 \pm 400$

Wood from $10 \mathrm{ft}$ below W-512 but just above the hasal bedding plane of the forest-bed silt.

W-514. Scranton no. 1 , basal till

Wood from basal $1 \mathrm{ft}$ of the bottom till.

W-640. Scranton no. 1, basal till

Wood from near base of lower till as exposed at road level. Not a rerun of W-514, but a recollected sample.

\section{W-517. Scranton no. 2, Iowa}

$13,910 \pm 400$

Wood from loess exposed in roadcut ca. $2.5 \mathrm{mi} \mathrm{N}$ of Scranton on county road $\mathrm{M}$ on the $\mathrm{S}$ valley slope of Raccoon River, in the NE1/4 sec. $26, \mathrm{~T} 84 \mathrm{~N}$, R $32 \mathrm{~W}\left(42^{\circ} 05^{\prime} \mathrm{N}\right.$ Lat, $94^{\circ} 32^{\prime} \mathrm{W}$ Long $)$, Greene County, Iowa. Section description in Ruhe, Rubin, and Scholtes (1957). Till (4l ft) of Cary age overlies loess $(4 \mathrm{ft})$ which in turn overlies another till $(16 \mathrm{ft})$, presumed to be of early Wisconsin age. Till of Kansan age $(2 \mathrm{ft})$ overlies sand and gravel $(5 \mathrm{ft})$ at the base. Sample came from $1 \mathrm{ft}$ below the top of the loess. Coll. 1956 and subm. by R. V. Ruhe, U. S. Dept. Agriculture, State College, New Mexico, and W. H. Scholtes, Iowa State University, Ames.

\section{East McCulloch peat series, Iowa}

Peat samples from bog at East McCulloch, in sec. 32, T 94 N, R 24, W $\left(42^{\circ} 54^{\prime} \mathrm{N}\right.$ Lat, $93^{\circ} 42^{\prime} \mathrm{W}$ Long), Hancock County, Iowa, were separated into a cellulose fraction ( $\mathrm{NaOH}$-insoluble) and humic acid-lignin fraction $(\mathrm{NaOH}-$ soluble) and dated. Samples were taken at significant breaks in the pollen sequence, as reported by Lane (1931). The peat lies on Mankato-age till at the inner margin of the Altamont moraine. Lane's pollen studies showed the following sequence from bottom to top: lake margin plants, coniferous forest, deciduous forest, grassland. Two cycles drier than present were recorded in the grassland part of the sequence. Dates show there has been very little migration of the more mobile fraction (humic acid), that the till beneath is older than $11,790 \mathrm{yr}$, and that grass became dominant in this region about 6580 в.P. Coll. 1955 and subm. by W. H. Scholtes, Iowa State University, Ames, and R. V. Ruhe, U. S. Dept. Agriculture, State College, New Mexico. (See Ruhe and others, 1957.)

W-551. Grass dominance zone, $\mathrm{NaOH}$-insoluble $\mathbf{6 5 7 0} \pm \mathbf{2 0 0}$

Peat at 6.5 to $7.5 \mathrm{ft}$ depth from lower more arid zone and beginning of grass dominance.

W-554. Grass dominance zone, NaOH-soluble $6580 \pm 200$ Humic acid-lignin fraction of W-551.

W-549. Coniferous-deciduous transition, NaOH-insoluble $8170 \pm 200$

Peat at 8.5 to $9.5 \mathrm{ft}$ depth from forest transition zone. 


\section{W-553. Coniferous-deciduous transition, $\mathrm{NaOH}-$-soluble}

$8110 \pm 200$

Humic acid-lignin fraction of W-549.

\section{W-548. Spruce-pine dominance, NaOH-insoluble}

Peat at 12.5 to $13 \mathrm{ft}$, immediately postglacial.

W-552. Spruce-pine dominance, NaOH-soluble $11,790 \pm \mathbf{2 5 0}$ Humic acid-lignin fraction of $\mathbb{W}-548$.

\section{W-557. Spruce-pine dominance, both fractions}

$10,050 \pm 250$

This sample was of carbonate prepared by burning sample in a furnace at the U. S. Dept. Agriculture Soil Survey Laboratory, Beltsville, Maryland. The young date suggests the possibility of added modern $\mathrm{CO}_{2}$ from the air during processing.

\section{Britt series, Iowa}

Wood and peat from a section containing a buried forest. Forest bed is exposed in a drainage ditch that extends along the E lines of secs. 17 and 8 , $\mathrm{T} 96 \mathrm{~N}, \mathrm{R} 25 \mathrm{~W}, 3 \mathrm{mi} \mathrm{N}$ of the town of Britt. The exact sample locality is $0.2 \mathrm{mi} \mathrm{N}$ of SE corner of sec. 8. T $96 \mathrm{~N}$, R $25 \mathrm{~W}\left(43^{\circ} 09^{\prime} \mathrm{N}\right.$ Lat, $93^{\circ} 47^{\prime} \mathrm{W}$ Long), Hancock County, Iowa. Complete section description and discussion of significance in Ruhe and Scholtes (1959). The drainage ditch has been dug in a valley train of outwash that debouches from the margin of the Algona moraine $1.5 \mathrm{mi}$ to the NW. The Altamont moraine lies SW of this locality. Section essentially consists of two outwashes separated by a peat bed. The buried peat, silt, and gravel at the base of the section are an earlier phase outwash of Algona age; the upper sands and silts are later phase outwashes deposited during construction of the Algona moraine. Coll. 1957 and subm. by R. V. Ruhe, U. S. Dept. Agriculture, State College, New Mexico, W. H. Scholtes, Iowa State University, Ames, and J. de Heinzelin.

W-626. Britt, wood

$12,970 \pm 250$ and sand.

Part of a tree rooted in place in a massive silt underlying $5 \mathrm{ft}$ of silt

\section{W-625. Britt, peat}

$13,030 \pm 250$

Cray-brown laminated woody peat underlying silt of W-626 and overlying $5 \mathrm{ft}$ of silt, sands, and gravels.

\section{Thompson Creek series, Iowa}

Wood samples (id. by D. W. Bensend) from deposits of alluvium in Thompson Creek watershed, Harrison County, Iowa. The alluvial fill of Thompson Creek represents a complex sequence of erosion, deposition, and organic matter accumulation. Deposits have been divided tentatively into bed groups with numbers 1 through 5 from base to top. This is part of a gully genesis study being conducted hy R. B. Daniels, U. S.Dept. Agriculture, Soil Conservation Service, Ames, Iowa. Samples coll. 1957, 1958 and 1959 and subm. by Daniels. 
W-701. Harrison County, GT 21-1

Tree trunk (box elder) from channel fill just above top of bed 4 in $\mathrm{E}$ bank of Thompson Creek, $100 \mathrm{ft}$ downstream from the junction of Thompson Creek and Watkins Branch, near SE corner of NW1/4 NW11/4 NE1/4 sec. 18, $\mathrm{T} 80 \mathrm{~N}, \mathrm{R} 42 \mathrm{~W}\left(41^{\circ} 44^{\prime} \mathrm{N}\right.$ Lat, $95^{\circ} 46^{\prime} \mathrm{W}$ Long $)$, Harrison County, Iowa.

W-799. Harrison County, GT 5-1

$1100 \pm 170$

$\log$ (walnut) from bed 4, from $\mathrm{N}$ bank of Thompson Creek, $350 \mathrm{ft} \mathrm{E}$ of bridge across Thompson Creek on section line of secs. 13 and 14, in SW1/4 $\mathrm{SW} 1 / 4$ sec. $13, \mathrm{~T} 80 \mathrm{~N}, \mathrm{R} 43 \mathrm{~W}\left(41^{\circ} 44^{\prime} \mathrm{N}\right.$ Lat, $95^{\circ} 47^{\prime} \mathrm{W}$ Long $)$, Harrison County, lowa.

W-699. Harrison County, GT 19-1

$1800 \pm 200$

Trunk of tree (willow) from top of bed 3 , from near $\mathrm{N}$ center of $\mathrm{SW} 1 / 4$ $\mathrm{SW} 1 / 4 \mathrm{SE} 1 / 4$ sec. 13 , T $80 \mathrm{~N}, \mathrm{R} 43 \mathrm{~W}\left(41^{\circ} 44^{\prime} \mathrm{N}\right.$ Lat, $95^{\circ} 47^{\prime} \mathrm{W}$ Long $)$, Harrison County, Iowa.

W-702. Harrison County, GT 1-1 $\quad \mathbf{2 0 2 0} \pm \mathbf{2 0 0}$

Log ( red elm) from top of hed 2, from $\mathrm{E}$ bank of Willow River trench at junction of Thompson Creek and Willow River, in SW1/4 SE $1 / 4$ sec. 14, T $80 \mathrm{~N}, \mathrm{R} 43 \mathrm{~W}\left(41^{\circ} 44^{\prime} \mathrm{N}\right.$ Lat, $95^{\circ} 47^{\prime} \mathrm{W}$ Long $)$, Harrison County, Iowa.

W-700. Harrison County, GT 52-1 $11,120 \pm 440$

Twigs (spruce) from top of bed 1, from near base of $S$ bank, $500 \mathrm{ft} \mathrm{E}$ of bridge across Thompson Creek on section line of secs. 13 and 14, in SW1/4 SW $1 / 4$ sec. 13, T $80 \mathrm{~N}, \mathrm{R} 43 \mathrm{~W}\left(41^{\circ} 44^{\prime} \mathrm{N}\right.$ Lat, $95^{\circ} 47^{\prime} \mathrm{W}$ Long), Harrison County, lowa.

W-881. Harrison County, willow drainage $14,300 \pm \mathbf{2 5 0}$

Wood from bed 1 in $\mathbb{W}$ bank of Willow Drainage Ditch, $100 \mathrm{ft} \mathrm{N}$ of tributary entering from the $\mathrm{W}$, in $\mathrm{SW}^{1 / 4}$ sec. $11, \mathrm{~T} 80 \mathrm{~N}, \mathrm{R} 43 \mathrm{~W}\left(41^{\circ} 45^{\prime}\right.$ N Lat, $95^{\circ} 47^{\prime}$ W Long), Harrison County, Iowa.

\section{Logan series, Iowa}

Wood from alluvium exposed in the Clark Limestone Company quarry, $2 \mathrm{mi} \mathrm{NW}$ of Logan, S of U. S. highway 30 in NW1/4 sec. 20 , T $79 \mathrm{~N}, \mathrm{R} 43 \mathrm{~W}$ ( $41^{\circ} 40^{\prime} \mathrm{N}$ Lat, $95^{\circ} 45^{\prime} \mathrm{W}$ Long), Harrison County, Iowa. Section consists of: $16 \mathrm{ft}$ of Tazewell-age loess capping $21 \mathrm{ft}$ of black and gray, silty to clayey loam resting on limestone bedrock. The overlying loess is calcareous. The underlying alluvium is noncalcareous, shows some bedding, and has several organic-rich layers. Coll. 1959 by J. R. Rubin, M. Rubin, and R. B. Daniels.
W-879. Logan quarry, upper wood
$19,050 \pm 300$

Spruce wood from gray silt loam under the Tazewell-age loess, at 19.4 ft depth.

W-880. Logan quarry, lower wood

$37,600 \pm 1500$ depth.

Spruce wood from black to very dark-gray silty clay loam at $30.2 \mathrm{ft}$

W-503. Fayette County, Iowa

$>29,000$

W-534. Fayette County, Iowa (rerun of W-503)

$>34,000$

Wood from the basal part of the lowan-age till in its type area in north- 
eastern Iowa. Exposed in a railroad cut of a NW-SE-trending paha in the $\mathrm{C}$ NE $1 / 2$ sec. 3, T $92 \mathrm{~N}$, R 8 W $\left(42^{\circ} 49^{\prime} \mathrm{N}\right.$ Lat, $91^{\circ} 46^{\prime} \mathrm{W}$ Long $)$, Fayette County, Iowa. Sample occurs in a zone of abundant organic matter at depth of 215 in. below Iowan till. This horizon rests on till, presumably Kansan in age, but with no recognizable paleosolum separating the two tills. Section described in detail in Ruhe, Rubin, and Scholtes (1957). Coll. 1956 and subm. by R. V. Ruhe, U. S. Dept. Agriculture, State College, New Mexico, and W. H. Scholtes, Iowa State University, Ames.

\section{W-516. Maynard, Iowa}

Wood from till of Iowan age exposed in railroad cut $1 \mathrm{mi} \mathrm{S}$ of Maynard, in NE $1 / 4$ sec. 27, T $92 \mathrm{~N}, \mathrm{R} 9 \mathrm{~W}\left(42^{\circ} 45^{\prime} \mathrm{N}\right.$ Lat, $91^{\circ} 53^{\prime} \mathrm{W}$ Long $)$, Fayette County, Iowa. This section, consisting of $17 \mathrm{ft}$ of till, is in the marginal part of the type Iowan drift. The wood, coming from the base of the section, suggests an overriding of a forested landscape by ice during Iowan time. Coll. 1956 and subm. by R. V. Ruhe, U. S. Dept. Agriculture, State College, New Mexico, and W. H. Scholtes, Iowa State University, Ames.

\section{W-591. Quimby, Iowa}

Wood from base of Iowan-age till exposed in roadcut on State highway 31, $3 \mathrm{mi}$ E of Quimby in SE1/4 sec. 5, T $90 \mathrm{~N}, \mathrm{R} 40 \mathrm{~W}\left(42^{\circ} 38^{\prime} \mathrm{N}\right.$ Lat, $95^{\circ}$ $36^{\prime} \mathrm{W}$ Long), Cherokee County, lowa. Section is $1.5 \mathrm{mi} \mathrm{E} \mathrm{(inside)} \mathrm{of} \mathrm{Iowan-}$ age drift border along Little Sioux River. For details of section, see Ruhe and Scholtes (1959). Section, from top to base, consists of : Iowan- and post-Iowanage loess, $2.5 \mathrm{ft}$; Iowan-age till topped by weak pebble band, $41.5 \mathrm{ft}$ ( sample horizon, wood disseminated in lower 38 in.) ; pre-Iowan-age silt, $3 \mathrm{ft}$; Kansanage till, gumbotil, $6 \mathrm{ft}$ to base of cut. This is the first date on Iowan-age till or northwestern Iowa; others are from northeastern Iowa. Coll. 1957 and subm. by R. V. Ruhe, U. S. Dept. Agriculture, State College, New Mexico, and W. H. Scholtes, Iowa State University, Ames.

\section{W-599. Central City, Iowa}

Wood from base of Iowan-age till in roadcut on $\mathrm{E}$ side of road, $3 \mathrm{mi} \mathrm{NW}$ of Central City, .125 mi N of C sec. 21, T 86 N, R 6 W $\left(42^{\circ} 14^{\prime}\right.$ N Lat, $91^{\circ} 30^{\prime}$ W Long), Linn County, Iowa. For details of section, see Ruhe and Scholtes (1959). Section, from top to base, consists of loamy soil, $3.5 \mathrm{ft}$; leached sand and gravel, $2 \mathrm{ft}$; Iowan-age till with weathering horizons, wood fragments disseminated throughout lower $43 \mathrm{in}$. in the unoxidized and unleached till (sample horizon), $10 \mathrm{ft}$; yellowish-brown calcareous sand and gravel, to base. Coll. 1957 and subm. by R. V. Ruhe, U. S. Dept. Agriculture, State College, New Mexico, and W. H. Scholtes, Iowa State University, Ames.

\section{W-600. Independence, Iowa}

Wood (hemlock) from gray silt immediately underlying lowan-age till from a cut along the Illinois Central Railroad, in NW1/4 sec. 3 , T $88 \mathrm{~N}, \mathrm{R} 8 \mathrm{~W}$, $5.5 \mathrm{mi} \mathrm{E}$ of Independence $\left(42^{\circ} 28^{\prime} \mathrm{N}\right.$ Lat, $91^{\circ} 48^{\prime} \mathrm{W}$ Long), Buchanan County, Iowa. Section description in Ruhe, Rubin, and Scholtes (1957), and discussion of the significance of this sample in Ruhe and Scholtes (1959). A previous sample, W-139 (USGS II), was collected from lower in the section 
and dated $>38,000$. W-600 lies immediately under the top till and 15 in. above a black peat which rests on a silt (W-139 sample horizon). Base of section consists of gray calcareous and unoxidized till. Coll. 1957 and subm. by R. V. Ruhe, M. Rubin, and R. Daniels.

W-520. Louisville, West, Kentucky

$18,530 \pm 500$

Wood from highly fossiliferous gray, sandy silt from base ( $\mathrm{S}$ side) of a small isolated hill which rises above the alluvium at the mouth of Big Run Creek Valley, $800 \mathrm{ft} \mathrm{S}$ on secondary road from St. Andrews Church Road, ca. $5 \mathrm{mi}$ E of U. S. highway 60, at Pleasure Ridge Park, Louisville, Kentucky. The fossiliferous silt is related to the Tazewell-age valley train along the Ohio River. Coll. 1956 and subm. by L. L. Ray, U. S. Geological Survey, Washington, D. C., and M. M. Leighton, Illinois State Geological Survey, Urbana.

W-521. Louisville, East, Kentucky

$<200$

Wood from base of gray silty alluvium above a noncalcareous blue, silty clay exposed in creek section, $250 \mathrm{ft} \mathrm{N}$ of bridge crossing of Gardiner Lane on South Fork Beargrass Creek, $0.12 \mathrm{mi} \mathrm{SW}$ of Lighthouse Lake, just beyond SE city limits of Louisville, Louisville East Quadrangle $\left(38^{\circ} 12^{\prime} \mathrm{N} \mathrm{Lat}, 85^{\circ}\right.$ $42^{\prime}$ N Long), Jefferson County, Kentucky. Coll. 1956 and subm. by L. L. Ray, U. S. Geological Survey, Washington, D. C., and M. M. Leighton, Illinois State Geological Survey, Urbana. Comment: the dated deposit was known only as post-Tazewell in age.

\section{W-712. Mammoth Cave, Kentucky}

Desiccated bat guano from Chief City Room, Mammoth Cave $\left(37^{\circ} 12^{\prime} \mathrm{N}\right.$ Lat, $86^{\circ} 06^{\prime} \mathrm{W}$ Long), Kentucky. The guano forms a dust layer, 6 in. thick, on slabs of collapsed rock, which rests on $10 \mathrm{ft}$ of cave fill of sand and silt. Coll. 1958 and subm. by W. E. Davies, U. S. Geological Survey, Washington, D. C.

\section{W-556. Lansing, Michigan}

$9040 \pm 300$

Wood embedded in peaty muck $\mathrm{S}$ of the Grand River at the NW corner of Lansing, in SE $1 / 4 \mathrm{SE}_{1}^{1} / 4 \mathrm{SW}^{1} / 4$ sec. 5 , T $4 \mathrm{~N}, \mathrm{R} 3 \mathrm{~W}\left(42^{\circ} 45^{\prime} \mathrm{N}\right.$ Lat, $84^{\circ} 40^{\prime}$ W Long), Ingham County, Michigan. Peat is under $15 \mathrm{ft}$ of what appeared to be till, undisturbed, and rests on clay at $24 \mathrm{ft}$. Later investigation indicates the overlying material is more likely modern fill. Coll. 1950 by Helen Martin, Water Resources Comm., Lansing, Michigan, and Leonard Wood, U. S. Geological Survey; subm. by N. Billings, Water Resources Comm., Lansing, through C. L. McGuinness, U. S. Geological Survey, Washington, D. C.

\section{W-693. White Pine, Michigan}

$9500 \pm 600$

Log buried beneath $35 \mathrm{ft}$ of uniform and apparently structureless pebbly clay from an excavation for the portal of a mine, slightly $\mathrm{N}$ of $\mathrm{C} \sec 4, \mathrm{~T} 50 \mathrm{~N}$, R $12 \mathrm{~W}\left(46^{\circ} 45^{\prime} \mathrm{N}\right.$ Lat, $89^{\circ} 34^{\prime}$ W Long $)$, White Pine, Michigan. Altitude of the surface at the site is ca. $885 \mathrm{ft}$; a beach ridge ca. $940 \mathrm{ft}$, a little $\mathrm{S}$ of the site, presumably marks a stage of Glacial Lake Algonquin. This is believed to be a piece of the same wood as sample L-239A, 12,600 \pm 1200 (Lamont III) . Coll. 1952 and subm. by W. S. White, U. S. Geological Survey, Washington, D. C. 


\section{W-500. Hibbing, Minnesota}

Wood bailed from well at $35 \mathrm{ft}$ in silty clay, underlying the surface red till and $30 \mathrm{ft}$ of outwash, in a test hole for the village of Hibbing, in SE1/4 $\mathrm{SW} 1 / 4 \mathrm{NW} 1 / 4$ sec. 19, T $57 \mathrm{~N}$, R $20 \mathrm{~W}\left(47^{\circ} 25^{\prime} \mathrm{N}\right.$ Lat, $92^{\circ} 57^{\prime} \mathrm{W}$ Long), St. Louis County, Minnesota. Coll. 1956 and subm. by B. A. Liesch, U. S. Geological Survey, St. Paul, Minnesota.

\section{W-501. Worthington, Minnesota}

Wood recovered from blue clay (till?) at $50 \mathrm{ft}$ depth in well at Worthing. ton, in NW1/4 NW1/4 NE1/4 sec. 32, T $102 \mathrm{~N}, \mathrm{R} 40 \mathrm{~W} 143^{\circ} 37^{\prime} \mathrm{N}$ Lat, $95^{\circ}$ 36' W Long), Nobles County, Minnesota. Coll. 1956 by R. F. Norvitch; subm. by R. Schneider, U. S. Geological Survey, St. Paul, Minnesota.

\section{W-502. Aitkin, Minnesota}

$11,710 \pm 325$

Cutoff of the Cutoff of the Mississippi River, $3 \mathrm{mi} \mathrm{N}$ of Aitkin $\left(46^{\circ} 34^{\prime} \mathrm{N}\right.$ Lat, $93^{\circ} 4 \mathrm{r}^{\prime} \mathrm{W}$ Long), Aitkin County, Minnesota. Coll. 1956 and subm. by R. Farnham and H. E. Wright, Jr., University of Minnesota, Minneapolis.

\section{W-574. Aitkin Cutoff, Minnesota}

$10,620 \pm 400$

Peat from drainage ditch tributary from near $\mathbb{W}$ end of Aitkin Cutoff ca. $5 \mathrm{mi} \mathrm{NW}$ of Aitkin $\left(46^{\circ} 35^{\prime} \mathrm{N}\right.$ Lat, $93^{\circ} 40^{\prime} \mathrm{W}$ Long), Aitkin County, Minnesota. Peat lies beneath $3 \mathrm{ft}$ of sand of Clacial Lake Aitkin (see W-502, this list). Intruded rootlets were visible in the sample. Although sample was picked clean, some rootlets may have remained. Coll. 1956 and subm. by H. E. Wright, Jr., University of Minnesota, Minneapolis.

\section{W-560. Lakefield, Minnesota $\quad 11,540 \pm 200$}

Wood (larch or spruce), from well $4 \mathrm{mi}$ W of Lakefield $\left(43^{\circ} 4 \mathrm{l}^{\prime} \mathrm{N}\right.$ Lat, $95^{\circ} 19^{\prime} \mathrm{W}$ Long), Jackson County. Minnesota. Sample taken from beneath $20 \mathrm{ft}$ of silt and above till at a locality $20 \mathrm{mi} \mathrm{E}$ (inside) of the Bemis moraine (Cary age) and $5 \mathrm{mi} \mathrm{W}$ (outside of the Altamont moraine (late Cary?). The silt cover is presumably related to the drainage from the Altamont moraine. Coll. 1953 (?) by Alvin Glasser; sulım. by H. E. Wright, Jr., University of Minnesota, Minneapolis.

\section{W-562. Lindford, Minnesota}

$4360 \pm 160$

Basal organic deposit (decomposed or aquatic peat) beneath $7 \mathrm{ft}$ of peat in bog $2 \mathrm{mi}$ E of Lindford, in NW $1 / 4 \mathrm{NE} 1 / 4$ sec. 5 , T $68 \mathrm{~N}, \mathrm{R} 26 \mathrm{~W}\left(48^{\circ} 27^{\prime}\right.$ $N$ Lat, $94^{\circ} 00^{\prime} \mathrm{W}$ Long), Koochiching County, Minnesota. The peat rests on fine sand of that stage of Glacial Lake Agassiz which postdated formation of Vermilion moraine (late Cary?). Although the bog may have originated in postglacial time, the date will give a minimum age for Lake Agassiz and the Vermilion moraine. Coll. 1956 by M. L. Heinselman; subm. by H. E. Wright,
Jr., University of Minnesota, Minneapolis.

\section{W-634. Jackson, Minnesota}

Wood from roadcut of Riverside Drive on $\mathrm{E}$ cit of Des $S$ edge of Jackson just $N$ of Old Seter Moines River at $\mathrm{R} 35 \mathrm{~W}\left(43^{\circ} 37^{\prime} \mathrm{V}\right.$ Lat, $91^{\circ} 59^{\prime} \mathrm{W}$ Iors , Jark, in NW $1 / 4$ sec. $24, \mathrm{~T} 102 \mathrm{~N}$, 
wood and peat layer under $35 \mathrm{ft}$ of gray till and above $25 \mathrm{ft}$ of gray till. Site is in the Gary moraine, but date indicates the till is not all of Mankato age but compares with that at Mankato, Minnesota, W-300, W-301 $>37,000$ (USCS IV) and Redwood Falls, Minnesota, W-99, >31,000 (USGS I). Coll. 1957 by R. V. Nordstrom, Soil Conservation Service, U. S. Dept. Agriculture, St. Paul, Minnesota; subm. by H. E. Wright, Jr., University of Minnesota, Minneapolis.

W-635. Round Lake, Minnesota $\quad \mathbf{1 2 , 0 9 0} \pm \mathbf{3 0 0}$

Wood (spruce) from farm of Jerry Onken, in SW $1 / 4$ sec. 10, T $101 \mathrm{~N}$, $\mathrm{R} 38 \mathrm{~W}$, Round Lake $\left(43^{\circ} 35^{\prime} \mathrm{N}\right.$ Lat, $95^{\circ} 25^{\prime} \mathrm{W}$ Long), Jackson County, Minnesota. Wood was uncovered in farm-pond excavation in a small ice-block depression at inner base of Bemis moraine (Cary age) on W side of Des Moines lobe. Section, from top of depression, consists of: black muck, $4 \mathrm{ft}$; gray clayey till (?), $3 \mathrm{ft}$; shell layer in sand, $6 \mathrm{in}$; gray clayey till (sample from here) to base. Site is inside ( $\mathrm{E}$ of) Bemis moraine, so material overlying wood, if till, may be interpreted as Cary-age till. This material might instead be solifluction and pond deposits (as suggested by shell layer) formed during retreat from Cary-age moraine, or during Mankato time, the terminal moraine of which is $15 \mathrm{mi} \mathrm{E}$ (Altamont moraine). Discussion of Minnesota dates in Wright and Rubin (1956). Coll. 1957 by R. V. Nordstrom; subm. by H. E. Wright, Jr., University of Minnesota, Minneapolis.

W-771. Lake Hanska, Minnesota $\quad 9800 \pm \mathbf{2 5 0}$

Buried peat, cored from depth of $6 \mathrm{ft}$ at Lake Hanska valley, SE of Lake Hanska, in SW $1 / 4$ sec. 11 , R 31 N, T 107 W (44. $05^{\prime}$ N Lat, 94 $32^{\prime}$ W Long), Watonwan County, Minnesota. Peat occurs just SW of the front of the Marshall moraine, a Mankato-age recessional moraine, younger than the Altamont and Algona moraines. Section, from top to hase, consists of: silt, $30 \mathrm{in}$; sand, 30 in.; clay, 9 in.; peat (sampled). 6 in.; coarse sand, to base. Coll. 1957 by J. Cummins, U. S. Dept. Agriculture, Soil Conservation Service; subm. by H. E. Wright, Jr., University of Minnesota, Minneapolis.

\section{Madelia series, Minnesota}

Peat and gyttja from excavation made in a drained swamp $1.25 \mathrm{mi} \mathrm{N}$ of Madelia, in sec. 14, T $107 \mathrm{~N}, \mathrm{R} 30 \mathrm{~W}\left(44^{\circ} 05^{\prime} \mathrm{N}\right.$ Lat, 94 $25^{\prime} \mathrm{W}$ Long), Watonwan County, Minnesota. Site is in a shallow depression just inside the Marshall moraine, which was formed hy the Des Moines lobe when the ice terminus stood at about Mankato, Minnesota. Samples come from top and bottom of a 2.5 - $\mathrm{ft}$ organic layer at $8 \mathrm{ft}$ depth, underlying clay and sand. The clay and sand is interpreted as a meltwater deposit or slope wash prior to post-glacial forestation of the region. Dates should thus record time just after retreat of Mankato-age ice from this locality. Coll. 1958 and subm. hy M. E. Fries and H. E. Wright, Jr., University of Minnesota, Minneapolis.

W-825. Madelia peat, top of organic layer $9300 \pm 350$

W-824. Madelia gyttja, bottom of organic layer 12,650 \pm 350

W-827. Gilbert, Minnesota $11,330 \pm 350$

Wood, peat, and clayey peat, taken from the Mariska mine, 1 mi E of 
Gilbert, in SW1 $1 / 4$ SE $1 / 4$ sec. 24 , T 58 N, R 17 W $\left(47^{\circ} 30^{\prime} \mathrm{N}\right.$ Lat, $92^{\circ} 29^{\prime} \mathrm{W}$ Long), Minnesota. Sample from the mine road in the SE corner of the pit, ca. $30 \mathrm{ft}$. below land surface. Organic matter underlies the clayey till, considered Lake Superior Valders age by H. E. Wright, Jr., and overlies a yellowish-brown till. Date should establish the time since the last interglacial in the Mesabi Range area. This date agrees with the Two Creeks age, thereby establishing the correlation of the Minnesota Valders (?) with the Wisconsin Valders. Section, from top to base, consists of: brown clayey till (Valders), $30 \mathrm{ft}$; contorted limonitic sand and gray clay, $6 \mathrm{ft}$; peat, containing wood fragments (sampled), 0.1 to $0.3 \mathrm{ft}$; limonitic sand and gray clay, cobble concentrate at top of unit, 0.6 to $1.0 \mathrm{ft}$; dark yellowish-brown clayey till, $6 \mathrm{ft}$. Coll. 1958 by H. B. Dyer, subm. by R. Schneider, U. S. Geological Survey, St. Paul, Minnesota.

\section{W-872. North Branch, Minnesota}

$2520 \pm 200$

Black organic clay involuted with layers of sand taken from drainage ditch leading $\mathrm{N}$ to tributary of Hay Creek, $3 \mathrm{mi}$ SE of North Branch, in $\mathrm{C}$ sec. 26, T $35 \mathrm{~N}, \mathrm{R} 21 \mathrm{~W}$ ( $45^{\circ} 30^{\prime} \mathrm{N}$ Lat, $92^{\circ} 57^{\prime} \mathrm{W}$ Long), Chisago County, Minnesota. Sample from depth of $1.5 \mathrm{ft}$. Pollen analyses show dominant pine in these organic layers. Wood and peat from below the sand layers were dated previously: W-354, 12,030 $\pm 200 ; \mathrm{W}-389,12,700 \pm 250$ (USGS IV). The involuted layers were thought to date from the Valders or, if not the result of permafrost, from the postglacial. The date indicates the latter. Coll. 1959 and subm. by H. E. Wright, Jr., University of Minnesota, Minneapolis.

\section{W-873. Weber Lake, Minnesota}

$10,550 \pm 300$

Organic matter from sediment core taken at $\mathrm{S}$ edge of Weber Lake, a small round lake, $0.5 \mathrm{mi} \mathrm{W}$ of State highway $2,35 \mathrm{mi} \mathrm{N}$ of Two Harbors, in sec. $36, T 58 \mathrm{~N}, \mathrm{R} 11 \mathrm{~W}\left(47^{\circ} 27^{\prime} \mathrm{N}\right.$ Lat, $91^{\circ} 40^{\prime} \mathrm{W}$ Long $)$, Lake County, Minnesota. Lake is bottomed on Cary-age till of drumlins. Pollen diagram (by M. Fries) shows basal spruce-tundra(?) zone followed by strong birch maximum. Depth to birch maximum was 720 to $740 \mathrm{~cm}$ below water surface, but core from 710 to $750 \mathrm{~cm}$ was needed for the $\mathrm{C}^{14}$ analysis. Two samples of the same core have been dated by the Uppsala laboratory (Uppsala II) : U-163, $7300 \pm 140 ;$ U-164, $9150 \pm 130$. Coll. 1959 and subm. by H. E. Wright, Jr., University of Minnesota, Minneapolis.

\section{Loup River Basin series, Nebraska}

Peat, logs, and shells from the highest and second-highest terraces along the Loup River drainage system. The terraces are correlated by the collector with the numbered terraces of Schultz (Schultz, Lueninghoener, and Frankforter, 1951). Coll. 1958 and subm. by J. C. Brice, U. S. Geological Survey, Lincoln, Nebraska.

\section{W-755. Loup River, LC-5}

$8400 \pm 250$

Peat from a deep cut on outside of meander, Loup River, 5 mi $\mathrm{E}$ of Brewster, near center sec. 5, T $22 \mathrm{~N}$, R $21 \mathrm{~W}\left(41^{\circ} 55^{\prime} \mathrm{N}\right.$ Lat, $99^{\circ} 48^{\prime} \mathrm{W}$ Long), Nebraska. From second-highest terrace along the Loup River, tentatively correlated with Schultz' R'T-1. Coll. from a $2-\mathrm{ft}$ peat bed near top of terrace, overlain by $26 \mathrm{ft}$ of sand. 
W-750. Loup River, LC-4

$9000 \pm 250$

Log exposed in cut bank of North Loup River, $6 \mathrm{mi}$ upstream from Brewster, in SW $1 / 2$ sec. 9, T $23 \mathrm{~N}, \mathrm{R} 23 \mathrm{~W}\left(41^{\circ} 58^{\prime} \mathrm{N}\right.$ Lat, $99^{\circ} 58^{\prime} \mathrm{W}$ Long), Nebraska. From second-highest terrace along the Loup River, tentatively correlated with Schultz' RT-1. Terrace fill consists of gray, fine, sandy clay at base, overlain by bed of peat 1 to $2 \mathrm{ft}$ thick, which is in turn overlain by ca. $10 \mathrm{ft}$ of cross-bedded sand. Log comes from peat bed.

W-752. Loup River, LC-6B

$10,500 \pm 250$

Mollusc shells from $W$ side of Cooper's Canyon, $300 \mathrm{ft}$ upstream from railroad trestle, in $\mathrm{NE} 1 / 4$ sec. 15 , T $15 \mathrm{~N}$, R $11 \mathrm{~W}\left(41^{\circ} 17^{\prime} \mathrm{N}\right.$ Lat, $98^{\circ} 34^{\prime}$ W Long), Elba Quadrangle, Nebraska. From major high terrace along the North Loup River. Correlated with Schultz' RT-2 by collector. Sample came from beneath a soil zone called "Cooper's Canyon Gley" by Miller and Scott (1955) and ascribed by these authors to a pre-Wisconsin age. Section is 40 ft high, consists of silt above gley soil, below which sample was collected, and of cross-bedded sand and gravel below the soil.

\section{W-754. Maywood, Nebraska}

$420 \pm 160$

Fragments of charcoal embedded in a matrix of wood ashes and silt from an exposure $2 \mathrm{mi} \mathrm{SE}$ of Maywood, near bridge where county road crosses Elkhorn Canyon, center of section line between sec. 31 and 32, T $8 \mathrm{~N}, \mathrm{R} 29 \mathrm{~W}$ $\left(40^{\circ} 39^{\prime} \mathrm{N}\right.$ Lat, $100^{\circ} 36^{\prime} \mathrm{W}$ Long), Frontier County, Nebraska. The charcoalbearing layer formed a thin lens interbedded with silts of the terrace fill. Coll. 1956 and subm. by J. C. Brice, U. S. Geological Survey, Lincoln, Nebraska.

\section{W-614. Omaha, Nebraska}

$2800 \pm 200$

Wood from streamcut of Ponca Creek, $\mathrm{N}$ of Omaha, in NE $1 / 4 \mathrm{SW} 1 / 4$ sec. 33, T $17 \mathrm{~N}, \mathrm{R} 13 \mathrm{E}\left(41^{\circ} 24^{\prime} \mathrm{N}\right.$ Lat, $95^{\circ} 58^{\prime} \mathrm{W}$ Long), Nebraska. From saturated blue-gray tight silt and clayey silt, underlying $26 \mathrm{ft}$ of silty alluvium, and overlying 6 to 18 in. of sand and gravel at stream level. Coll. 1951 and subm. by R. D. Miller, U. S. Geological Survey, Denver, Colorado.

\section{W-618. Fort Calhoun, Nebraska}

$22,200 \pm 1000$

Wood fragments from a log in gray tight silt exposed $1.75 \mathrm{mi} \mathrm{N}$ and $1 \mathrm{mi}$ W of Fort Calhoun, in $\mathrm{SE}^{1} / 4 \mathrm{SW} 1 / 4$ sec. $34, \mathrm{~T} 18 \mathrm{~N}, \mathrm{R} 12 \mathrm{E}\left(41^{\circ} 27^{\prime} \mathrm{N}\right.$ Lat, $96^{\circ} 03^{\prime} \mathrm{W}$ Long), Washington County, Nebraska. Section consists of $30 \mathrm{ft}$ of tan stratified silt forming the Fort Calhoun terrace, $45 \mathrm{ft}$ of gray tight silt, and base in limestone of Pennsylvanian age. Wood came from $10 \mathrm{ft}$ below the overlying tan silt and $20 \mathrm{ft}$ above modern floodplain. Coll. 1956, interpreted, and subm. by R. D. Miller, U. S. Geological Survey, Denver, Colorado. Comment: the Fort Calhoun terrace is a prominent feature in the history of alluviation of the Missouri River valley. Its deposition may well coincide with the period of major loess deposition and perhaps resulted when the Missouri River was choked with silt to provide a thickness of alluvium in excess of $80 \mathrm{ft}$. A similar terrace surface is found along the major streams of Nebraska; thus this date might apply elsewhere in Nebraska, i.e., along the Republican, Platte, Elkhorn and Loup Rivers. 
Buried wood (white spruce) exposed in excavation in the Altamont moraine, $10 \mathrm{mi} \mathrm{S}$ of Tappen on the Wolt farm. $200 \mathrm{ft} \mathrm{SW}$ of the center of sec. 25, T 138 N, R 7l W $\left(46^{\circ} 45^{\prime} \times\right.$ Lat, $99^{\circ} 37^{\prime}$ W Long), Kidder County, North Dakota. From $12 \mathrm{ft}$ depth, underlying black to gray sand, and overlying in turn: sand, $3 \mathrm{ft}$; clay, $16 \mathrm{ft}$; till, $6 \mathrm{ft}$; gravel, $14 \mathrm{ft}$; till $3 \mathrm{ft}$, hase of excavation in bedrock (Fox Hills sandstone). Discussion of section by Moir (1957). Coll. 1956 by G. L. Bell; subm. hy R. W. Lemke, U. S. Geological Survey, Denver, Colorado.

\section{W-723. Grand Forks, North Dakota}

$10,960 \pm 300$

Wood excavated from sand in recently opened drainage ditch, $15 \mathrm{mi} W$ of Grand Forks, in NW1/4 sec. 31, T $152 \mathrm{~N}$, R $52 \mathrm{~W}\left(47^{\circ} 56^{\prime} \mathrm{N}\right.$ Lat, $97^{\circ} 22^{\prime}$ W Long), Grand Forks County, North Dakota. Sample horizon is overlain by $10 \mathrm{ft}$ of silt and sand and is underlain by till. Coll. 1958 and subm. by R. W. Lemke, U. S. Geological Survey, Denver, Colorado, and H. E. Wright, Jr., University of Minnesota, Minneapolis. Comment: till underlying the fossil wood is believed to have been deposited by the ice lohe that deposited the EdinburgHolt moraines and represents the last ice adrance into North Dakota. Sample provides a minimum date for this till.

\section{W-648. Wright-Patterson Air Base, Ohio $\quad 21,600 \pm 400$}

Wood from near base of till exposed in excaration for Air Force nuclear test reactor on Wright-Patterson Air Base, SW of Fairborn $\left(39^{\circ} 47^{\prime} \mathrm{N}\right.$ Lat, $84^{\circ}$ 03' W Long), Beaver Township, (Greene County, Ohio. Section, from top to base, consists of: sand-and-gravel, 0 to $8 \mathrm{ft}$; till, oxidized, 3 to $7 \mathrm{ft}$; till, unoxidized, 3 to $4 \mathrm{ft}$ (wood comes from this till); clay, 0 to $6 \mathrm{in}$; ; peat, .125 to $.25 \mathrm{in}$.; silt, with swamp debris, 4 to $14 \mathrm{in}$.; sand-and-gravel, 3 to $6 \mathrm{ft}$; base in blue clay of Ordovician age. Coll. 1957 by J. L. Forsyth and A. Spieker, Ohio State Geological Survey, Columbus; sulm. by S. E. Norris, U. S. Geological Survey, Columbus.

\section{Hamilton series, Ohio}

Log from till, $21 \mathrm{ft}$ below the surface. and carbon from soil at $25.5 \mathrm{ft}$, at W end of Lagonda St., NW edge of Hamilton, in SW 1/4 NE1/4 sec. 29, T $4 \mathrm{~N}$, R 3 E $\left(39^{\circ} 25^{\prime} \mathrm{N}\right.$ Lat, $84^{\circ} 33^{\prime} \mathrm{W}$ Long $)$, Butler County, Ohio. From a till sheet $25 \mathrm{ft}$. thick, which rests on a middle $\mathbb{W}$ isconsin-age paleosol, 18 in. thick, in alluvial sand and gravel, overlying $17 \mathrm{ft}$ of gray, calcareous till. This basal till lies on a Sangamon-age paleosol, $100 \mathrm{in}$. thick, in Illinoian-age till. This is the first section in Ohio in which a middle $W$ isconsin-age paleosol is exposed in one and the same section stratigraphically above a Sangamon-age paleosol. The importance of this dated section to the interpretation of the length of the Wisconsin stage would be difficult to orerestimate. Coll. 1958 and subm. by R. P. Coldthwait, Ohio State University, Columbus.
W-724. Wood from upper till $19,100 \pm 300$
W-738. Carbonaceous matter from soil
$18,750 \pm 300$
Soil in streaky carbonaceous, alluvial sand, mostly leached; middle Wisconsin-age paleosol. 


\section{W-773. Humboldt, Ohio}

Peat from a section exposed near Humboldt $\left(39^{\circ} 17^{\prime} \mathrm{N}\right.$ Lat, $83^{\circ} 19^{\prime} \mathrm{W}$ Long), (,reenfield Quadrangle, Ross County, Ohio, described in Goldthwait (1955, p. 47). Section, from top to hase, consists of: $20 \mathrm{ft}$ of till capped by 6 in. of silt with a 50- to 60 -in. soil considered to be of early Wisconsin age; $20 \mathrm{ft}$ of clay; 2 in. to $1 \mathrm{ft}$ of peat (sampled) ; 3 to $7 \mathrm{ft}$ of marl with molluses; 3 to $5 \mathrm{ft}$ of gravel; $8 \mathrm{ft}$ of till; $10 \mathrm{ft}$ of gravel at hase. This basal gravel appears to correlate with a gravel $600 \mathrm{ft}$ away, which lies directly under upper till and which has an unquestionable Sangamon-age weathering profile developed in it. Coll. 1958 and subm. by J. L. Forsyth, Ohio State Ceological Survey, Columbus.

\section{W-801. Miner County, South Dakota}

Wood fragments collected on the Laurence McElvain farm, NE $1 / 4$ sec. 36, T $106 \mathrm{~N}, \mathrm{R} 58 \mathrm{~W}\left(43^{\circ} 57^{\prime} \mathrm{N}\right.$ Lat, $97^{\circ} 42^{\prime} \mathrm{W}$ Long), Miner County, South Dakota. Found near the bottom of a dugout in a creek bed, ca. $12 \mathrm{ft}$ helow the surface. Section, from top to hase, consists of: alluvium, $2 \mathrm{ft}$; alluvium with many pebbles. $1 \mathrm{ft}$; brown oxidized till, $5 \mathrm{ft}$; gray unoxidized till, $3 \mathrm{ft}$; silt, to base. The wood fragments were taken from the silt. Coll. 1958 and subm. by A. F. Agnew, South Dakota State Ceological Survey, Vermillion.

\section{W-590. Scott, Wisconsin \\ $11,140 \pm 300$}

Wood from forest bed exposed on the Norbert Peters' farm, Scott, in sec. 23, T 24, N. R 21 E (44, $34^{\prime}$ N Lat, $87^{\circ} 52^{\prime}$ W Long), Brown County, Wisconsin. Sample was part of a tree trunk, $10 \mathrm{in.}$ in diam., in an organic-rich, silt-and-sand layer, $7 \mathrm{ft}$ thick, containing tree trunks and forest litter. Sample horizon is at $18 \mathrm{ft}$ depth, overlain by red clay and gray till at the surface. Red clay underlies the forest bed. Coll. 1957 and subm. by R. Pfleger, University of Wisconsin, Green Bay Extension.

\section{W-638. Lake Geneva, Wisconsin}

$31,800 \pm 1200$

Wood (spruce) from hluff summit along the $\mathrm{S}$ side of Lake Ceneva, 3.6 mi E of Fontana ( $42^{\circ} 33^{\prime} \mathrm{N}$ Lat, $88^{\circ} 30^{\prime} \mathrm{W}$ Long), Walworth County, Wisconsin. Sample is a piece of a tree trunk $3.5 \mathrm{ft}$ long and $8 \mathrm{in}$. in diam., found embedded vertically but inverted, in pink, dense, clayey till, at a depth of 15 to $20 \mathrm{ft}$. For details, see Black (1958). Wood identified by J. Kryn, Forest Product Lahoratory, Madison, at the request of R. F. Black, University of Wisconsin. Sample coll. 1957 and subm. by J H. Bretz, University of Chicago, Illinois.

W-641. Lake Poygan, Waushara County, Wisconsin $\mathbf{1 2 , 0 0 0} \pm \mathbf{5 0 0}$

Peat from a layer continuous for over 2 to $3 \mathrm{sq}$. mi exposed in drainage ditch in C W1/2 SE $1 / 4$ SW $1 / 4$ sec. 25 , T 19 N, R 13 E $\left(44^{\circ} 05^{\prime} \mathrm{N}\right.$ Lat, $88^{\circ} 55^{\prime}$ W Long), Waushara County, Wisconsin. Peat is in a hed, 4 in. thick, overlain by 2 to 4 ft of gray, calcareous clay and underlain by beach sands. Red, dolomitic, clayey till underlies the whole area. The sample site is 10 to $15 \mathrm{ft}$ higher than the present stage of Lake Poygan. The sand, peat, and clay were deposited during a high lake stage, which may be last stage of Later Lake Oshkosh. 
Coll. 1957 and subm. by W. K. Summers, U. S. Geological Survey, Madison, Wisconsin.

\section{Two Creeks series, Wisconsin}

Wood from the much-dated Two Creeks forest bed horizon exposed on the Lake Michigan bluffs, $1.5 \mathrm{mi}$ NE of Two Creeks, in NE1/4 NE $1 / 4$ sec. 2 , T 21 N, R 24 E (44 $19^{\prime}$ N Lat, $87^{\circ} 33^{\prime}$ W Long), Manitowoc County, Wisconsin. Coll. 1957 by M. Rubin and dated after processing the sample with an acid-alkali-acid treatment. As age of W-670 seemed slightly out of line with the many other determinations made of this horizon, an additional run was made on a similar sample (W-698) coll. at the same time by J. R. Rubin, the author's son. Comment: both samples were given the same pretreatment; the dates illustrate the range that might be expected in dating the same horizon. Actually, the range of dates from this horizon as dated by several laboratories is greater than the following example.

$$
\begin{array}{ll}
\text { W-670. } & \text { Two Creeks, Father } \\
\text { W-698. } & \text { Two Creeks, Son }
\end{array}
$$

$$
\begin{aligned}
& 12,200 \pm 400 \\
& 11,550 \pm 300
\end{aligned}
$$

W-747. Hammond, Wisconsin

$29,000 \pm 1000$

Wood fragments at depth of $14 \mathrm{ft}$ in blue-gray till, exposed $3 \mathrm{mi} \mathrm{SW}$ of Hammond, in NW $1 / 4 \mathrm{SW} 1 / 4$ sec. 6 , T $28 \mathrm{~N}, \mathrm{R} 17 \mathrm{~W}\left(44^{\circ} 56^{\prime} \mathrm{N}\right.$ Lat, $92^{\circ} 30^{\prime}$ W Long), St. Croix County, Wisconsin. Coll. 1958 and subm. by R. F. Black and T. E. Berg, University of Wisconsin, Madison. For discussion of sample and significance, see Black (1959). Comment: the till in which the wood is found has been mapped as Illinoian age by Leverett, and Kansas age according to Weidman. It is considered by Black to be the original Farmdale-age (of P. Shaffer) advance in this area, equivalent to the Lake Geneva locality (W-638, this list).

W-762. Red Granite, Waushara County, Wisconsin $12,220 \pm 250$

Peat from depth of $4 \mathrm{ft}$ under red and gray clays, from near Red Granite, in center NW $1 / 4 \mathrm{SE}^{1} / 4$ sec. 10 , T $18 \mathrm{~N}, \mathrm{R} 12 \mathrm{E}\left(44^{\circ} 04^{\prime} \mathrm{N}\right.$ Lat, $89^{\circ} 03^{\prime} \mathrm{W}$ Long), Waushara County, Wisconsin. Collected by 3.5 -in. bucket auger from sediments in an abandoned stream channel. Coll. 1958 and subm. by W. K. Summers, U. S. Geological Survey, Madison.

W-820. Wautoma, Waushara County, Wisconsin $10,420 \pm 300$

Peat from kettle $N$ of Wautoma, in NW1/4 SE $1 / 4$ NE $1 / 4$ sec. 31 , T $19 \mathrm{~N}$, $\mathrm{R} 10 \mathrm{E}\left(44^{\circ} 05^{\prime} \mathrm{N}\right.$ Lat, $89^{\circ} 20^{\prime} \mathrm{W}$ Long), Waushara County, Wisconsin. Taken from the bottom $1 \mathrm{ft}$ of sediments that had filled a kettle in an outwash plain of the Eldoron morainic system. Section, from top to base, consists of: fresh peat, $12 \mathrm{ft}$; marl, $2 \mathrm{ft}$; rubbery peat, $1 \mathrm{ft}$ (sampled); gravel, to base. Coll. 1956 and subm. by W. K. Summers, U. S. Geological Survey, Madison.

\section{Western United States}

\section{W-621. Hopi Buttes, Tsegi formation, Arizona}

$3100 \pm 250$

Charcoal from buried hearth at base of upper member of Tsegi formation (Hack, 1941) where Tsegi fills channel cut into Jeddito formation (Hack, 1941) at Hopi Buttes, T $23 \mathrm{~N}, \mathrm{R} 21 \mathrm{E}\left(35^{\circ} 24^{\prime} \mathrm{N}\right.$ Lat, $110^{\circ} 06^{\prime} \mathrm{W}$ Long), 
Navajo County, Arizona. Hearth is contemporaneous with deposition of the sandy alluvium of the Tsegi formation. One flaked chip of stone recovered from fire pit. Tsegi at this locality is pre-Pueblo but post-human habitation. Coll. 1956 and subm. by E. M. Shoemaker, U. S. Geological Survey, Grand Junction, Colorado.

W-622. Hopi Buttes, Naha formation, Arizona $\quad 1040 \pm 250$

Charcoal from hearth in silty alluvium in upper part of shallow alluvial fan of Naha formation (Hack, 1941), Hopi Buttes, T $23 \mathrm{~N}, \mathrm{R} 21 \mathrm{E}\left(35^{\circ} 24^{\prime}\right.$ $\mathrm{N}$ Lat, $110^{\circ} 06^{\prime} \mathrm{W}$ Long), Navajo County, Arizona. At sample locality, the Naha formation rests without conspicuous unconformity on the underlying Tsegi formation, but in the headwaters of the fan, the Naha fills a channel cut into the Tsegi. Hearth is of a Pueblo campfire associated with abundant artifacts, including potsherds, flaked chert, and metate. Potsherds belong to two contemporaneous types: Little Colorado White Ware, and Tusayan Corrugated (id. by H. S. Colton, Museum of Northern Arizona). Coll. 1957 and subm. by E. M. Shoemaker, U. S. Geological Survey, Grand Junction, Colorado.

\section{W-581. Colma, California $\quad \mathbf{1 0 , 5 4 0} \pm \mathbf{3 5 0}$}

Wood from near base of terrace exposed $5650 \mathrm{ft} \mathrm{S} 24^{\circ} \mathrm{W}$ of town hall of Colma, in San Francisco South Quadrangle $\left(37^{\circ} 40^{\prime} \mathrm{N} \mathrm{Lat,} 122^{\circ} 28^{\prime} \mathrm{W}\right.$ Long), California. From a stream terrace deposited in a deep channel of a type cut after the middle Pleistocene orogeny. Terraces have since been incised 50 $\mathrm{ft}$ or more. Sample occurs in gravel-and-sand layer underlying $39 \mathrm{ft}$ of silt and sand. Base of the section is at $50 \mathrm{ft}$; sample dates close to onset of alluviation, probably due to climatic change. Coll. 1956 and subm. by M. G. Bonilla, U. S. Geological Survey, Menlo Park, California.

W-629. Bodie, California

$700 \pm 200$

Carbonized wood from top of lower ash bed, $10.3 \mathrm{mi} \mathrm{E}$ of Bodie, on road to Hawthorne ( $38^{\circ} 19^{\prime} \mathrm{N}$ Lat, $118^{\circ} 55^{\prime} \mathrm{W}$ Long), California. Wood is $10 \mathrm{ft}$ above Bodie Creek and underlies an upper ash bed. Coll. 1957 and subm. by D. B. Slemmons and W. Lundy, University of Nevada, Reno.

\section{Lassen National Park series, California}

Charcoal from beneath two flows of different ages in Lassen National Park. Coll. 1956 and subm. by G. A. Macdonald, University of Hawaii, Honolulu, Oahu.

W-759. Lassen C-1

$510 \pm 160$

Charcoal from pine tree trunk at base of one of the youngest stratigraphic units in the area, probably the youngest. At $\mathbb{W}$ edge of big flow from Cinder Cove, $0.97 \mathrm{mi} \mathrm{NE}$ of the summit of the cove, in sec. 9 , T $31 \mathrm{~N}, \mathrm{R} 6 \mathrm{E}\left(40^{\circ} 33^{\prime}\right.$ $30^{\prime \prime}$ N Lat, $121^{\circ} 18^{\prime} 25^{\prime \prime}$ W Long), Lassen National Park, California.

\section{W-758. Lassen C-2}

$1320 \pm 200$

Charcoal from tree branch embedded in poorly sorted gravel, a glowing avalanche or hot mudflow deposit, underlying the deposits of the 1915 glowing avalanches from Lassen Peak. In E bank of Lost Creek, $200 \mathrm{ft}$ below crossing of highway, in sec. 14, T $31 \mathrm{~N}, \mathrm{R} 4 \mathrm{E}\left(40^{\circ} 32^{\prime} 24^{\prime \prime} \mathrm{N}\right.$ Lat, $121^{\circ} 29^{\prime} 30^{\prime \prime} \mathrm{W}$ Long), Lassen National Park, California. 
W-812. Manzanita Creek, California

Carbonized $\log$ buried beneath $3.5 \mathrm{ft}$ of dacite tuff, lapilli, and bombs from SW bank of Manzanita Creek, $900 \mathrm{ft}$ SE of Manzanita Campground along road to water storage area $\left(40^{\circ} 32^{\prime} \mathrm{N}\right.$ Lat. $121^{\circ} 32^{\prime} \mathrm{W}$ Long), Lassen National Park, California. Surface area has an ahundance of bombs. Coll. 1958 by R. G. Prasil, Lassen National Park; subm. hy B. Cale, National Park Service, San Francisco, California.

\section{W-727. Mammoth Mountain, California}

$1440 \pm 150$

Charred wood fragments exposed in roadcut on switchback on road up Mammoth Mountain, in C sec. $31, \mathrm{~T} 3 \mathrm{~S}, \mathrm{R} 27 \mathrm{E}\left(37^{\circ} 39^{\prime} \mathrm{N}\right.$ Lat, $119^{\circ} 02^{\prime} \mathrm{W}$ Long), Devil's Postpile Quadrangle, California. Sample occurs in a stratified sand-and-gravel unit, $1 \mathrm{ft}$ thick, underlying $l \mathrm{ft}$ of coarse pumice. Underlying the sample horizon is a 2-ft deposit of large houlders in sand and gravel. Coll. 1957 and subm. by N. K. Huher, U. S. Ceological Survey, Washington, D. C.

\section{W-734. Horseshoe Lake, California}

$4830 \pm 200$

Charred wood fragments from gravel pit $.25 \mathrm{mi} \mathrm{N}$ of Horseshoe Lake, in C sec. 8, T 4, S, R 27 E $\left(37^{\circ} 37^{\prime}\right.$ N Lat, $119^{\circ} 01^{\prime}$ W Long), Devil's Postpile Quadrangle, California. From a sand-and-gravel deposit, 1 ft thick, at a depth of $4 . \mathrm{ft}$, underlying $2.5 \mathrm{ft}$ of fine sand and $1.5 \mathrm{ft}$ of coarse pumice at the surface. Boulders underlie the sample horizon. Coll. 1957 by C. D. Rinehart; subm. by N. K. Huber, U. S. Ceological Surrey, Washington, D. C.

\section{Sherman Island series, California}

Peat from cores in the Sacramento-San Joaquin delta. Cores were taken on Sherman Island, $400 \mathrm{ft} \mathrm{N}$ of of $\mathrm{N}$ hank of San Joaquin River, $1000 \mathrm{ft} \mathrm{E}$ of $\mathrm{N}$ end of Antioch bridge in sec. 10, T $2 \mathrm{~N}, \mathrm{R} 2 \mathrm{E}\left(38^{\circ} 02^{\prime} \mathrm{N}\right.$ Lat, $121^{\circ} 46^{\prime} \mathrm{W}$ Long), Sacramento County, California. The hole was drilled through the thickest section of peat in the delta. Peat or organic silts extend from the surface to $61 \mathrm{ft}$ below the surface. Sands occur from $61 \mathrm{ft}$ to bottom of hole at 84 $\mathrm{ft}$. Coll. 1957 by M. McKinney, California Dept. of Water Resources; subm. by J. F. Poland, U. S. Ceological Survey, Sacramento, California.
W-794. Core SH 1-X4, no. B 2780
$6600 \pm 250$
Organic silt with peat, 32.5 to $33.0 \mathrm{ft}$ depth.
W-744. Core SH $1-X 4$, no. B 2788

$$
10,690 \pm 300
$$

Organic silt with clay, 57.5 to $58.0 \mathrm{ft}$ depth.

\section{W-793. Arroyo Hondo, California}

$1040 \pm 200$

Charcoal from hearth huried $10.5 \mathrm{ft}$ below land surface in alluvial fan sediments. Sample taken from S wall of Arroyo Hondo, $1200 \mathrm{ft} \mathrm{SW}$ of powerlines, in NE $1 / 4 \mathrm{SE} 1 / 4$ sec. 3, T $17 \mathrm{~S}$. R $12 \mathrm{E}$ ( $36^{\circ} 27^{\prime} \mathrm{N}$ Lat, $120^{\circ} 35^{\prime} \mathrm{W}$ Long), Lillis Ranch Quadrangle, Fresno County, California. Coll. 1958 by W. B. Bull; subm. by J. F. Poland, U. S. Ceological Survey, Sacramento, California.

\section{W-616. Van Bibber Creek, Colorado $\quad 1050 \pm 250$}

Charcoal from streamcut in an Indian site on the $\mathrm{S}$ bank of Van Bibber Creek, in SE $1 / 4 \mathrm{SE} 1 / 4$ sec. 8 , T $3 \mathrm{~S}, \mathrm{R} 70 \mathrm{~W}\left(39^{\circ} 48^{\prime} \mathrm{W}\right.$ Lat, $105^{\circ} 15^{\prime} \mathrm{W}$ Long), Golden Quadrangle, Colorado. The (hareal is associated with artifacts 
in a 1 - $\mathrm{ft}$ zone lying $2 \mathrm{ft}$ beneath the Piney Creek terrace and $3 \mathrm{ft}$ above the present floodplain. Coll. 1956 and subm. by R. Van Horn, U. S. Geological Survey, Denver, Colorado.

W-802. Boxelder Arroyo, Colorado

$1800 \pm 160$

Charcoal from firehole in buried soil in $\mathrm{S}$ bank of Boxelder Arroyo, $50 \mathrm{ft}$ W of E line of sec. 8, T $10 \mathrm{~N}, \mathrm{R} 69 \mathrm{~W}\left(40^{\circ} 50^{\prime} \mathrm{N}\right.$ Lat, $105^{\circ} 09^{\prime} \mathrm{W}$ Long), Livermore Quadrangle, Larimer County, Colorado. Sample horizon is overlain by $4.5 \mathrm{ft}$ of floodplain alluvium and underlain by more alluvium. Coll. 1958 and subm. by D. V. Harris, Colorado State University, Fort Collins.

\section{W-822. Lake City, Colorado $\quad \mathbf{7 0 0} \pm \mathbf{2 0 0}$}

Fragment of log enclosed in Slumgullion mudflow, exposed $1000 \mathrm{ft}$ SW of State highway 149, bridge over Lake Fork, ca. 2 mi S of Lake City $\left(38^{\circ} 00^{\prime}\right.$ $\mathrm{N}$ Lat, $107^{\circ} 18^{\prime} \mathrm{W}$ Long), Colorado. The Slumgullion mudflow is the largest ( $6 \mathrm{mi}$ long) of many similar mudflows; the lower part is more than $700 \mathrm{yr}$ old by tree ring count; the upper part is now moving, but trees on it indicate formation at least $330 \mathrm{yr}$ ago. Coll. 1958 and subm. by D. R. Crandell, U. S. Geological Survey, Denver, Colorado.

\section{W-856. Waiohinu, Hawaii}

$3740 \pm 250$

Charcoal found under pahoehoe flow in churchyard at Waiohinu, Island of Hawaii ( $19^{\circ} 04^{\prime} \mathrm{N}$ Lat, $155^{\circ} 37^{\prime} \mathrm{W}$ Long), Hawaii. This flow is the last to come off the Mauna Loa slope in this area, prior to the witnessed branch of the 1868 flow. Coll. 1959 and subm. by K. J. Murata, U. S. Geological Survey, Hawaii National Park, Hawaii.

\section{Lake Thatcher series, Idaho}

Shells of freshwater clam Sphaerium sulcatum (Lamarck), id. by H. B. Herrington, Westbrook, Ontario, Canada. These clams lived in Lake Thatcher, which was formed by lava dammning the Bear River and diverting its flow from the Snake River drainage. The lake rose to a maximum elevation of $5484 \mathrm{ft}$, stood long enough to create a beach, and then overflowed southward into Lake Bonneville at the Bonneville stage. Because the Bear River contributes approximately $43.5 \%$ of the inflow to the Bonneville basin, this event is considered to be the most logical cause of the overflow of Lake Bonneville at Red Rock Pass into the Snake River. The samples, from the lake beds deposited in Lake Thatcher, should date from the time of existence of the lake, the Bonneville stage of Lake Bonneville, the spillover at Red Rock Pass, and from the approximate time of the damming by basalts. The above interpretation is based on field investigations made by R. C. Bright, University of Minnesota, Minneapolis, who coll. the samples in 1957 and 1958. Samples subm. by D. W. Taylor, U. S. Geological Survey, Washington, D. C.

W-704. Thatcher, no. MC-6

$32,500 \pm 1000$

Shells from a very fossiliferous, tuffaceous marl, from a marker horizon in a very complicated series of lake beds of Lake Thatcher. Exposed in the $\mathrm{N}$ side of a roadcut at altitude $5290 \pm 5 \mathrm{ft}$, in $\mathrm{SW}_{1} 1 / 4 \mathrm{SE} 1 / 4$ sec. $7, \mathrm{~T} 12 \mathrm{~S}, \mathrm{R} 41$ E $\left(42^{\circ} 24^{\prime} \mathrm{N}\right.$ Lat, $111^{\circ} 42^{\prime} \mathrm{W}$ Long), Preston Quadrangle, near Thatcher, Idaho. 
W-855. Thatcher, Idaho, no. 34-6D

$27,500 \pm 1000$

Shells from a 2 -ft channel sample in lacustrine silt exposed in a roadcut at altitude $5170 \pm 5 \mathrm{ft}$, on E side of Idaho State highway 34, 1 telephone pole $\mathrm{N}$ of telephone pole no. 245 , in NE1/4 NE1/4 sec. T $11 \mathrm{~S}, \mathrm{R} 40 \mathrm{E}\left(42^{\circ} 27^{\prime} \mathrm{N}\right.$ Lat, $111^{\circ} 42^{\prime} \mathrm{W}$ Long), Preston Quadrangle, Bannock County, Idaho.

\section{W-731. American Falls reservoir, Idaho}

$29,700 \pm 1000$

Freshwater shells from sand pits in pebbly sand overlying the American Falls Lake beds, in NE $1 / 4$ NE $1 / 4$ sec. $15, \mathrm{~T} 6 \mathrm{~S}, \mathrm{R} 31 \mathrm{E}$, near the edge of the American Falls reservoir ( $42^{\circ} 54^{\prime} 20^{\prime \prime} \mathrm{N}$ Lat, $112^{\circ} 48^{\prime} 50^{\prime \prime} \mathrm{W}$ Long), American Falls Quadrangle, Bingham County, Idaho. Shells are from a terrace, probably identical to deposits on the opposite side of the reservoir, which by their torrential bedding seem to represent spillover by Lake Bonneville. Possibly, however, these shells are slightly younger than the torrential deposits, as they may be from a terrace cut slightly lower. The shells pre-date Snake River entrenchment (see W-704 and W-855, this list.) Coll. 1958 by W. J. Carr; subm. by H. E. Malde, U. S. Geological Survey, Denver, Colorado.

W-594. Cascade, Montana

$8800 \pm 300$

Shells taken from undercut bank of the Missouri River, $2 \mathrm{mi} \mathrm{NE}$ of Cascade, in SE1/4 NE1/4 sec. 24, T $18 \mathrm{~N}, \mathrm{R} 1 \mathrm{E}\left(47^{\circ} 20^{\prime} \mathrm{N}\right.$ Lat, $111^{\circ} 39^{\prime} \mathrm{W}$ Long), Montana. Samples consists of large clam shells taken from sandy silt at depth of $9.2 \mathrm{ft}$, underlying silt and ash layers and overlying silts and sands with a base of silt and clay of Glacial Lake Great Falls. A nearly complete bison skeleton was also taken from the shell horizon. Coll. 1956 and subm. by R. W. Lemke and E. K. Maughan, U. S. Geological Survey, Denver, Colorado.

\section{Sawtooth ranch series, Montana}

Snail shells and wood from a ditch which is a northwesterly tributary of Willow Creek, just NW of Sawtooth ranch and road from Augusta to Sun River Canyon, in NE1/4 SE1/4 sec. 27, T $21 \mathrm{~N}, \mathrm{R} 7 \mathrm{~W}\left(47^{\circ} 33^{\prime} \mathrm{N}\right.$ Lat, $112^{\circ}$ $30^{\prime}$ W Long), Montana. Section, from top to base, consists of: silty clay, with bison bones and a thin volcanic-ash layer, $2.6 \mathrm{ft}$; clay, calcareous, $1.7 \mathrm{ft}$; clay, lacustrine, calcareous, faint laminae, $3 \mathrm{ft}$ to base. The basal clay represents deposits in a lake dammed by the Pinedale 2 moraines and the Pinedale 3 glacier. Coll. 1958 and subm. by R. M., R. J., and M. R. Mudge, U. S. Geological Survey, Denver, Colorado.

W-765. Sawtooth ranch, F 209A

Snail shells from silty clay at $2.6 \mathrm{ft}$ depth.

W-774. Sawtooth ranch, F 210C

$7870 \pm 200$

Wood from basal clay. Lab, comment: large number of modern \pm 200 present, making this date unsatisfactory.

W-775. Stoners Flats, Montana

$7280 \pm 400$

Peat lentil from Stoners Flats, headwaters of Beaver Creek, which drains to the $\mathrm{N}$ fork of the Sun River $\left(47^{\circ} 31^{\prime} \mathrm{N}\right.$ Lat, $112^{\circ} 44^{\prime} \mathrm{W}$ Long), Montana. From peat layer at depth of $3.5 \mathrm{ft}$ below the surface, interbedded with a volcanic-ash bed believed to be Glacier Peak ash. Coll. 1958 and subm. by M. W. Reynolds and M. R. Mudge, U. S. Geological Survey, Denver, Colorado. 


\section{W-803. Reno, Nevada}

$>30,000$ (or less than $2 \%$ of modern)

Aragonite deposited in a well $10 \mathrm{mi} \mathrm{S}$ of Reno $\left(39^{\circ} 24^{\prime} \mathrm{N}\right.$ Lat, $119^{\circ} 46^{\prime}$

W Long), Nevada. Deposited between December 24 and 28, 1951. Coll. and subm. by D. E. White, U. S. Geological Survey, Washington, D. C.

\section{W-804. Steamboat Springs, Nevada}

$25,000- \pm 700$ (or $4.2 \%$ of modern)

Calcite from top of S wall, Steamboat well, Steamboat Springs $\left(32^{\circ} 42^{\prime}\right.$ $\mathrm{N}$ Lat, $106^{\circ} 36^{\prime} \mathrm{W}$ Long), Nevada. Deposited during the month prior to June 22, 1953. Coll. and subm. by D. E. White, U. S. Geological Survey, Washing. ton, D. C.

\section{W-703. Cottonwood Springs, New Mexico}

$320 \pm 160$

Carbonized corn-on-the-cob from hearth in a prehistoric pueblo site on the Cottonwood Springs alluvial fan, in NE $1 / 4 \mathrm{SW}^{1} / 4$ sec. 27 , T $18 \mathrm{~S}$, R $3 \mathrm{E}$ ( $32^{\circ} 42^{\prime} \mathrm{N}$ Lat, $106^{\circ} 36^{\prime} \mathrm{W}$ Long), Bear Peak Quadrangle, Dona Aña County, New Mexico. Hearth was excavated at depth of $20 \mathrm{in}$. Slight soil development is evident in the debris that mantles the hearth. Coll. 1957 and subm. by R. V. Ruhe, U. S. Dept. Agriculture, State College, New Mexico.

\section{Southwest Caliche series, Texas and New Mexico}

Caliche from near the surface from exposures in Texas and New Mexico. The activity was measured as part of a program on caliche genesis. The ages were computed, using the age-corrected 1890 wood standard as the initial activity, and no correction was made for $\mathrm{C}^{12} / \mathrm{C}^{13}$ fractionation.

W-787. Rio Grande City no. 4, Texas $\quad 2200 \pm 250$

Banded caliche from top of caliche section exposed in roadcut of State highway $755,250 \mathrm{ft}$ above Rio Grande River, $4 \mathrm{mi}$ NE of Rio Grande City $\left(26^{\circ} 26^{\prime} \mathrm{N}\right.$ Lat, $98^{\circ} 44^{\prime} \mathrm{W}$ Long), Starr County, Texas. The caliche is here developed in a conglomerate. Section consists of a few in. of soil overlying a massive caliche with a dense banded layer at the soil-caliche contact (sampled).

\section{W-790. Rio Grande City no. 5, Texas}

Caliche from $4 \mathrm{ft}$ below top banded layer in massive caliche of same section and locality as W.787 above.

\section{W-788. Rachal no. 2, Texas}

$28,000 \pm 1500$

Caliche from pit near Stewart-Gougher well, $5 \mathrm{mi} \mathrm{SW}$ of Rachal $\left(26^{\circ} 50^{\prime}\right.$ N Lat, $98^{\circ} 13^{\prime}$ W Long), Brooks County, Texas. Section consists of $3 \mathrm{ft}$ of soil above $12 \mathrm{ft}$ of pisolitic caliche, with a dense solution and redeposition layer of caliche at the contact of the two. Sample from the wallrock of a solution kettle $3 \mathrm{ft}$ deep and $2 \mathrm{ft}$ in diam. in the contact layer.

W-789. Rachal no. 3, Texas

Caliche from the pisolitic layer, $4 \mathrm{ft}$ below the top of the soil-caliche contact, in the same section and locality as W-788 above.

\section{W-791. Beeville, Texas}

Caliche from roadcut on U. S. highway 181, $3 \mathrm{mi} \mathrm{N}$ of Beeville $\left(28^{\circ} 28^{\prime}\right.$ $\mathrm{N}$ Lat, $97^{\circ} 45^{\prime} \mathrm{W}$ Long), Bee County, Texas. Section consists of 6 in. of soil overlying massive caliche, with a 10 -in, zone of platy caliche at the contact. 
Sample from the massive caliche, at a depth of $3.5 \mathrm{ft}$ below the ground surface. The five samples above coll. 1958 and subm. by H. Eargle and M. Rubin, U. S. Geological Survey, Austin, Texas, and Washington, D. C.

W-792. Brackettville, Texas

$11,730 \pm 300$

Platy caliche from a thin layer under $10 \mathrm{in}$. of soil exposed in a pit, on $\mathrm{S}$ side of U. S. highway $90,7 \mathrm{mi} \mathrm{W}$ of Brackettville $\left(29^{\circ} 18^{\prime} \mathrm{N} \mathrm{Lat}, 100^{\circ} 30^{\prime}\right.$ W Long), Kinney County, Texas. Calcareous silt and sand underlie the sample horizon with a thickness of $7 \mathrm{ft}$ exposed. Coll. 1958 and subm. by J. C. Frye through D. L. Graf, Illinois State Geological Survey, Urbana, Illinois.

W-786. Fillmore Arroyo, New Mexico $\quad 11,900 \pm 300$

Banded caliche exposed in $\mathrm{N}$ bank of Fillmore Arroyo, $1500 \mathrm{ft} \mathrm{E}$ of pipeline, in SE $1 / 4$ sec. 19, T $23 \mathrm{~S}, \mathrm{R} 3 \mathrm{E}\left(32^{\circ} 17^{\prime} \mathrm{N}\right.$ Lat, $106^{\circ} 40^{\prime} \mathrm{W}$ Long), Organ Peak Quadrangle, New Mexico. -Sample horizon underlies 10 in. of weathered gravel and overlies $3 \mathrm{ft}$ of massive caliche. From the appearance and induration of this typical capping layer, it is called "troweled calcrete."

W-796. Las Cruces no. 102, New Mexico $\quad \mathbf{2 0 , 3 0 0} \pm \mathbf{8 0 0}$

Stringers of $\mathrm{CaCO}_{3}$ in $\mathrm{B}$ zone of buried soil exposed in pipeline cut near Las Cruces, in NE $1 / 4$ sec. 36, T $22 \mathrm{~S}$, R 2 E $\left(32^{\circ} 20^{\prime} \mathrm{N}\right.$ Lat, $106^{\circ} 41^{\prime} \mathrm{W}$ Long), Organ Peak Quadrangle, Dona Aña County, New Mexico. Section consists of $1 \mathrm{ft}$ of calichified gravel at the top, overlying a buried A soil zone above a B zone, with vertical stringers of carbonate (sampled) and a basal layer of nodular caliche.

W-797. Las Cruces no. 103, New Mexico

Caliche from basal layer in the same section and locality as W-796 above. The stringers of carbonate in the $\mathrm{B}$ zone descend to this basal layer. If the $\mathrm{C}^{14}$ activity of W-796 was the same as in this sample, one could say that the two carbonates formed during the same cycle. The three New Mexico samples above coll. 1958 and subm. by M. Rubin, U. S. Geological Survey, Washington, D. C., R. B. Grossman, and R. V. Ruhe, U. S. Dept. Agriculture, State College, New Mexico.

W-819. Fillmore Arroyo, New Mexico

$2620 \pm 200$

Charcoal from hearth site in the $\mathrm{N}$ bank of Fillmore Arroyo, Dona Aña Bend Grant Colony, $1500 \mathrm{ft} \mathrm{SW}$ of power line in T $24 \mathrm{~S}, \mathrm{R} 2 \mathrm{E}\left(32^{\circ} 13^{\prime} \mathrm{N}\right.$ Lat, $106^{\circ} 42^{\prime} \mathrm{W}$ Long), Dona Aña County, New Mexico. Hearth is $4 \mathrm{ft}$ below a surface which is tentatively named the no. 3 Geomorphic surface by the submitter. Coll. 1958 by L. H. Gile and R. B. Grossman; subm. by R. V. Ruhe, U. S. Dept. Agriculture, State College, New Mexico.

\section{W-628. Bandon, Oregon \\ $>38,000$}

Wood from friable sandstone at Pioneer mine, $5 \mathrm{mi} \mathrm{N}$ of Bandon, in NE $1 / 4$ sec. 33 , T $27 \mathrm{~S}, \mathrm{R} 14 \mathrm{~W}\left(43^{\circ} 11^{\prime} \mathrm{N}\right.$ Lat, $124^{\circ} 22^{\prime} \mathrm{W}$ Long), Bandon Quadrangle, Oregon. Sample from log $40 \mathrm{ft}$ down from top of " $200 \mathrm{ft}$ " terrace, immediately above a semiconsolidated conglomerate which rests on black sands. Coll. 1956 and subm. by P. D. Snavely, Jr., U. S. Geological Survey, Menlo Park, California. 
W-646. Nye Beach, Newport, Oregon

Wood from sand and silt ca. $23 \mathrm{ft}$ below surface of terrace in cliff $500 \mathrm{ft}$ SE of Jump Off Joe, Nye Beach, Newport, $4800 \mathrm{ft} \mathrm{W}, 2250 \mathrm{ft}$ S, NE corner sec. 5, T 11 S, R 11 W (44, $39^{\prime}$ N Lat, $124^{\circ} 04^{\prime}$ W Long), Yaquina Quadrangle, Oregon. Coll. 1956 and subm. by P. D. Snavely, Jr., U. S. Geological Survey, Menlo Park, California.

Sandy River series, Oregon

Wood from deposits of the Sandy River mudflow, a large post-pleistocene mudflow that fills the Sandy River valley. The mudflow was generated on the W slopes of Mount Hood and covers the late-glacial features. The forest that has developed since the mudflow is immature, and growth rings indicate that it is around $176 \mathrm{yr}$ old. The activity of the samples indicates ages of around $200 \mathrm{yr}$, but investigation of recent fluctuations in atmospheric $\mathrm{C}^{14}$ concentrations (and thus initial activity of the wood) make it prudent to quote the age as a minimum rather than an absolute figure. Coll. 1956 and subm. by A. C. Waters, The Johns Hopkins University, Baltimore, Maryland.

W-601. Sandy River, Oregon

Wood from a stump buried at the edge of Sandy River mudflow, beneath logging road bridge, in bed of Sandy River, in SE1/4 sec. 19, T $2 \mathrm{~S}, \mathrm{R} 8 \mathrm{E}$ ( $45^{\circ} 23^{\prime} \mathrm{N}$ Lat, $121^{\circ} 52^{\prime} \mathrm{W}$ Long), Clackamas County, Oregon.

W-661. Lost Creek, Oregon

Wood from a stump buried in Sandy River mudflow, $50 \mathrm{ft}$ downstream from temporary logging bridge over Lost Creek, in $\mathrm{SE}^{1} / 4 \mathrm{NE} 1 / 4$ sec. 20 , T $2 \mathrm{~S}$, R $8 \mathrm{E}$ ( $45^{\circ} 24^{\prime} \mathrm{N}$ Lat, $121^{\circ} 51^{\prime} \mathrm{W}$ Long), Clackamas County, Oregon.

\section{W-858. Crater Lake, Oregon}

$6640 \pm 250$

Charcoal found buried in pumice in roadcut between Roseburg and Diamond Lake, $27 \mathrm{mi} \mathrm{NW}$ of Crater Lake $\left(43^{\circ} 20^{\prime} \mathrm{N}\right.$ Lat, $122^{\circ} 42^{\prime} \mathrm{W}$ Long), Oregon. The pumice is believed to be from the Mount Mazama eruption. Coll. 1939 by G. R. Moore; subm. by L. J. Briggs, National Geographic Society, Washington, D. C., through the National Park Service. Comment: date agrees very well with the average of four dates measured by Chicago: C-247, 6453 \pm 250 (Chicago I).

\section{W-538. Leamington, Utah}

$13,050 \pm 400$

Wave-formed tufa containing snail shells found on quartzite hill $1.5 \mathrm{mi}$ SW of Leamington (see Delta, Utah sheet, NJ 12-1 of U.S.G.S. 1:250,000 Western U. S. series) $\left(39^{\circ} 30^{\prime} 50^{\prime \prime} \mathrm{N}\right.$ Lat, $112^{\circ} 15^{\prime} 00^{\prime \prime}$ W Long), Utah. Altitude of sample was between 5000 and $5100 \mathrm{ft}$; sample thus may date the Bonneville stage of Lake Bonneville. Coll. 1956 and subm. by J. H. Feth, U. S. Geological Survey, Menlo Park, California.

\section{W-807. Table Mountain, Utah}

$18,500 \pm 600$

Ostracodal marl, white, silty, and platy, from near top of bluff at $4500 \mathrm{ft}$ altitude, in vicinity of Gilbert's Lower Old River Bed section, in SE1/4 sec. 1, T $10 \mathrm{~S}, \mathrm{R} 10 \mathrm{~W}\left(40^{\circ} 00^{\prime} \mathrm{N}\right.$ Lat, $112^{\circ} 56^{\prime} \mathrm{W}$ Long $)$, Table Mountain Quadrangle, Utah. Sample from the prominent white marl of that section. Coll. 1957 by D. J. Varnes; subm. by R. Van Horn, both of the U. S. Geological Survey, Denver, Colorado. 
Calcareous, salty clay with selenite, at $4430 \mathrm{ft}$ altitude in bluff, in NW1/4 sec. 27, T $9 \mathrm{~S}, \mathrm{R} 10 \mathrm{~W}\left(40^{\circ} 02^{\prime} \mathrm{N}\right.$ Lat, $112^{\circ} 57^{\prime} \mathrm{W}$ Long), Camels Back Ridge SW Quadrangle, Utah. This section is $3 \mathrm{mi}$ distant from W-807, and the sample comes from lower in the section, separated from it by fluvial(?) deposits. Coll. 1957 by D. J. Varnes; subm. by R. Van Horn, U. S. Geological Survey, Denver, Colorado.

\section{Promontory Point series, Utah}

Shells and wood from large gravel pit on the $\mathrm{S}$ tip of Promontory Point $\left(41^{\circ} 14^{\prime} \mathrm{N}\right.$ Lat, $112^{\circ} 29^{\prime} \mathrm{W}$ Long), Boxelder County, Utah, W of Ogden. Tremendous exposures were made in the sediments of Lake Bonneville in order to obtain material for the new embankment of the Southern Pacific R.R. across Great Salt Lake. Three gravel spits were uncovered at near-Provo levels. Samples were collected from above the middle-elevation spit. Stratigraphy at the site where the wood was collected was so disturbed by the gravel pit operation that the relation of the bog deposits, from which the wood came, to the spit is questionable.

\section{W-875. Promontory Point shells}

$10,000 \pm 2000$

Shells from a yellowish silt overlying a gravel spit at $4835 \mathrm{ft}$ altitude. The silt is overlain by colluvium which in turn is overlain by lake beds with a distinctive pink-marker bed. Coll. 1959 by Rex Wright, Minneapolis, Minnesota.

W-876. Promontory Point wood

Wood from bog deposits $600 \mathrm{ft} \mathrm{S}$ of W-875 and at ca. $4775 \mathrm{ft}$ altitude. Coll. 1959 by J. R. Rubin and M. Rubin.

\section{W-864. Weber River, Utah}

$12,500 \pm 300$

Marl from section exposed on NW wall of a small canyon extending NE from the floodplain of Weber River into Uintah bench, in $\mathrm{SW}^{1} 1 / 4$ sec. 21 , T $5 \mathrm{~N}, \mathrm{R} 1 \mathrm{~W}\left(41^{\circ} 10^{\prime} \mathrm{N}\right.$ Lat, $111^{\circ} 57^{\prime} \mathrm{W}$ Long), Weber County, Utah. From base of a $13-\mathrm{ft}$ marl-and-clay bed, immediately above a peat bed, l-in. thick, at $4600 \mathrm{ft}$ altitude. This is a rerun of W-382, 12,960 \pm 350 (USGS IV). Coll. 1957 by J. H. Feth, U. S. Geological Survey, Menlo Park, California, and M. Rubin.

\section{W-529. Underwood, Washington}

Wood from mudflow exposed in a roadcut near Underwood, in $\mathrm{SE} 1 / 4$ NE $1 / 4$ sec. 23 , T $3 \mathrm{~N}$, R 10 E ( $45^{\circ} 44^{\prime}$ N Lat, $121^{\circ} 31^{\prime}$ W Long $)$, Klickitat County, Washington. The mudflow overlies Columbia River gravels that were deposited in a lake dammed by an olivine basalt flow. Coll. 1956 and subm. by A. C. Waters, The Johns Hopkins University, Baltimore, Maryland.

\section{W-558. Willapa Bay, Washington \\ $>35,000$}

Wood from till in a raised shoreline in Willapa Bay, Bay Center, 1 mi $\mathrm{S}$ of Goose Point $\left(46^{\circ} 37^{\prime} \mathrm{N}\right.$ Lat, $123^{\circ} 59^{\prime}$ W Long), Willapa Bay, Washington. Section along shore cliff consists of terrace deposits from the Columbia River overlying an oyster bed resting on the till with the wood fragments. Coll. 1955 and subm. by Trevor Kincaid, University of Washington, Seattle. 
Wood from mudflow exposed on NE bank of Puyallup River in SE $1 / 4$ sec. 25 , T $20 \mathrm{~N}, \mathrm{R} 4 \mathrm{E}$, at gas pipeline crossing $\mathrm{S}$ of Sumner $\left(47^{\circ} 12^{\prime} \mathrm{N}\right.$ Lat, $122^{\circ} 14^{\prime}$ W Long), Washington. Sample is part of a 12-in. log taken from the top of the mudflow surface, which underlies alluvium. This mudflow, associated with volcanic activity of Mount Rainier, is probably the downvalley facies of the Osceola mudflow. Coll. 1956 and subm. by D. R. Crandell, U. S. Geological Survey, Denver, Colorado.

\section{W-565. Electron, Washington}

$\mathbf{5 3 0} \pm \mathbf{2 0 0}$

Wood from $\mathrm{S}$ bank of Puyallup River ca. $300 \mathrm{ft}$ upstream from railroad bridge at Electron, in the $\mathrm{SE} 1 / 4$ sec. 32 , T $18 \mathrm{~N}, \mathrm{R} 5 \mathrm{E}\left(46^{\circ} 59^{\prime} \mathrm{N}\right.$ Lat, $122^{\circ}$ $12^{\prime}$ W Long). Washington. From the Electron mudflow which is inferred to have originated during a Recent eruption of Mount Rainier. Coll. 1959 and subm. by D. R. Crandell, U. S. Geological Survey, Denver, Colorado.

\section{W-566. Mowich River, Washington $\quad 2170 \pm 200$}

Log from mudflow exposed in roadcut just $\mathrm{N}$ of confluence of Mowich River and Puyallup River, in the NE $1 / 4$ sec. 3 , T $16 \mathrm{~N}, \mathrm{R} 6 \mathrm{E}\left(46^{\circ} 54^{\prime} \mathrm{N}\right.$ Lat, $122^{\circ} 02^{\prime} \mathrm{W}$ Long), Pierce County, Washington. Another example of a mudflow originating during an eruption of Mount Rainier. Mudflow here is similar to Osceola mudflow, but is younger, as shown by the dates and the soil development. Coll. 1956 and subm. by D. R. Crandell, U. S. Geological Survey, Denver, Colorado.

\section{W-671. Renton, Washington}

Wood from stratified sand exposed in excavation $1.5 \mathrm{mi}$ NW of Renton, in $\mathrm{NE}^{1 / 4} \mathrm{SW} 1 / 4$ sec. 12 , T $23 \mathrm{~N}$, R $4 \mathrm{E}\left(47^{\circ} 30^{\prime} \mathrm{N}\right.$ Lat, $122^{\circ} 15^{\prime} \mathrm{W}$ Long $)$, Renton Quadrangle, Washington. Sample lies in the basal $\mathrm{ft}$ of sand over a gray, clayey till and is separated from the surface Vashon-age (Wisconsin stage) till by about 10 to $15 \mathrm{ft}$ of lacustrine sand and $10 \mathrm{ft}$ of Vashon-age advance gravel. The gray, clayey till underlying the sample is widespread in and around Seattle, usually separated from the Vashon till by only a few $\mathrm{ft}$ of glacio-lacustrine sediments. No nonglacial sediments have been found in this stratigraphic position. Coll. 1957 by D. R. Mullineaux; subm. by H. H. Waldron, U. S. Geological Survey, Seattle, Washington.

\section{W-672. Sumner, Washington}

Peat from gully in valley wall, $1 \mathrm{mi} \mathrm{NE}$ of Sumner at ca. $200 \mathrm{ft}$ altitude, in SW $1 / 4 \mathrm{SE} 1 / 4$ sec. 18 , T $20 \mathrm{~N}$, R $5 \mathrm{E}\left(47^{\circ} 13^{\prime} \mathrm{N}\right.$ Lat, $122^{\circ} 13^{\prime} \mathrm{W}$ Long $)$, Sumner Quadrangle, Washington. From a 2 - $\mathrm{ft}$ layer overlying 2 to $3 \mathrm{ft}$ of volcanic ash and underlying two gravelly outwashes, the top one of Vashon age. Underlying the peat and ash are two drifts separated by a nonglacial sand formation. Coll. 1957 by D. R. Mullineaux; subm. by H. H. Waldron, U. S. Geological Survey, Seattle, Washington.

\section{W-673. McDonald Creek, Washington}

Wood from base of cross-bedded outwash sand exposed in sea cliff $\mathbb{W}$ of the mouth of McDonald Creek, $450 \mathrm{ft} W, 1225 \mathrm{ft} N$ of SE corner of sec. 6 , T $30 \mathrm{~N}, \mathrm{R} 4 \mathrm{~W}\left(48^{\circ} 07^{\prime} \mathrm{N}\right.$ Lat, $123^{\circ} 14^{\prime} \mathrm{W}$ Long $)$, Carlsborg Quadrangle, 
Washington. The wood is overlain in turn by $30 \mathrm{ft}$ of sand, $10 \mathrm{ft}$ of gravel, $10 \mathrm{ft}$ of till, and $50 \mathrm{ft}$ of sand and gravel to the surface. It is underlain by $15 \mathrm{ft}$ of iron-stained gravel and $5 \mathrm{ft}$ of clay and peat at the base. Coll. 1957 and subm. by P. D. Snavely, Jr., U. S. Geological Survey, Menlo Park, California.

\section{W-706. Pierce County, Washington}

$1950 \pm 200$

Log buried in sands in a kettle in Vashon-age drift, exposed at Voight Creek, in NE $1 / 4 \mathrm{NE} 1 / 4$ sec. 19 , T $18 \mathrm{~N}$, R $6 \mathrm{E}\left(47^{\circ} 02^{\prime} \mathrm{N}\right.$ Lat, $122^{\circ} 05^{\prime} \mathrm{W}$ Long), Pierce County, Washington. Coll. 1953 and subm. by D. R. Crandell, U. S. Geological Survey, Denver, Colorado.

\section{W-746. Wind Mountain, Washington}

Wood from gravel deposit in road metal quarry, at $\mathrm{W}$ base of Wind Mountain, in SW $1 / 4$ SE $1 / 4$ sec. $26, T 3 \mathrm{~N}, \mathrm{R} 8 \mathrm{E}\left(45^{\circ} 43^{\prime} \mathrm{N}\right.$ Lat, $121^{\circ} 46^{\prime} \mathrm{W}$ Long), Skamania County, Washington. Sample from $22 \mathrm{ft}$ depth in foresetbedded delta built by Wind River into a lake ponded in Columbia River gorge by blocking of the Columbia River by olivine basalt flows. Coll. 1958 and subm. by A. C. Waters, The Johns Hopkins University, Baltimore, Maryland.

\section{Arrow Lake series, Washington}

Peat overlying and underlying Glacier Peak ash at Arrow Lake in center $\mathrm{NE} 1 / 4$ sec. $6, \mathrm{~T} 22 \mathrm{~N}, \mathrm{R} 4 \mathrm{E}\left(47^{\circ} 25^{\prime} \mathrm{N}\right.$ Lat, $122^{\circ} 21^{\prime} \mathrm{W}$ Long), Des Moines Quadrangle, Washington. Coll. 1958 and subm. by H. H. Waldron, U. S. Geological Survey, Denver, Colorado.

\section{W-777. Peat above Glacier Peak ash \\ W-776. Peat below Glacier Peak ash}

$$
\begin{aligned}
& 6630 \pm 400 \\
& 6600 \pm 400 \\
& 5950 \pm 400
\end{aligned}
$$

W-779. Bow Lake, Washington

Peat overlying Glacier Peak ash at Bow Lake, in center of $\mathrm{E}$ side of sec. 33, T $23 \mathrm{~N}$, R 4 E ( $47^{\circ} 26^{\prime} \mathrm{N}$ Lat, $122^{\circ} 18^{\prime} \mathrm{W}$ Long), Des Moines Quadrangle, Washington. Coll. 1958 and subm. by H. H. Waldron, U. S. Geological Survey, Denver, Colorado.

\section{W-811. Gilmore Corners, Washington}

$2030 \pm 240$

Partially charred fragments from stem and lateral limb of conifer (not a root), taken from bank in gravel pit near Gilmore Corners, in SW1/4 NE1/4 sec. 30 , T 10 N, R 1 E $\left(46^{\circ} 18^{\prime}\right.$ N Lat, $122^{\circ} 44^{\prime}$ W Long), Cowlitz County, Washington. Pit is in material making flat-topped terrace of Toutle River which extends to Silver Lake. Sample from the upper $1 \mathrm{ft}$ of debris or mudflow deposit, which is in turn overlain by $3 \mathrm{ft}$ of pebble gravel and $14 \mathrm{ft}$ of debris or mudflow deposit. Sample submitted to date formation of Silver Lake and Spirit Lake by mudflows from Mount St. Helens. Modern Mount St. Helens is younger than the wood dated. Coll. 1958 and subm. by D. R. Mullineaux, U. S. Geological Survey, Seattle, Washington.

\section{W-535. Anchorage, Alaska}

\section{Alaska}

Peat from bluff on SE side of Eagle River, $N$ of Anchorage, in SW1/4 
SW $1 / 4$ SE $1 / 4$ sec. 9, T 14 N, R 2 W $\left(61^{\circ} 19^{\prime}\right.$ N Lat, $149^{\circ} 39^{\prime}$ W Long $)$, Alaska. From a layer that underlies till considered Naptowne in age and overlies gravel that may be pre-Naptowne in age. Coll. 1956 and subm. by R. D. Miller, E. Dobrovolny, and W. R. Hansen, U. S. Geological Survey, Denver, Colorado.

W-536. Fire Island peat, Alaska

$9300 \pm 250$

Peat from bluff on Fire Island, near Anchorage, along $\mathrm{S}$ bluff $1.1 \mathrm{mi} \mathrm{E}$ from Fire Island light $\left(61^{\circ} 07^{\prime} \mathrm{N}\right.$ Lat, $150^{\circ} 16^{\prime} \mathrm{W}$ Long), Alaska. The bluff is $60 \mathrm{ft}$ high with active dunes on top. Peat bed overlies thin pond deposits that in turn directly overlie till that forms the upper part of the bluff. Silt continues to the bottom of the bluff. Coll. 1956 and subm. by R. D. Miller and W. R. Hansen, U. S. Geological Survey, Denver, Colorado.

W-541. Fire Island log, Alaska

$620 \pm 200$

Log buried in place by dune sand on Fire Island, near Anchorage, 0.6 mi NE along $\mathrm{E}$ coast of Fire Island from Fire Island Triangulation station $\left(61^{\circ} 08^{\prime} \mathrm{N}\right.$ Lat, $150^{\circ} 13^{\prime} \mathrm{W}$ Long), Alaska. From vertical bluff, under ca. $12 \mathrm{ft}$ of dune sand, and above a podsol soil developed on gravel. Coll. 1956 and subm. by R. D. Miller and W. R. Hansen, U. S. Geological Survey, Denver, Colorado.

W-540. Knik Arm, Alaska

$11,600 \pm 300$

Peat from near top of sea cliff along Knik Arm, SW of Anchorage, ca. $400 \mathrm{ft} W$ of section line into sec. $21, \mathrm{~T} 13 \mathrm{~N}, \mathrm{R} 4 \mathrm{~W}\left(61^{\circ} 12^{\prime} \mathrm{N}\right.$ Lat, $150^{\circ} 00^{\prime}$ W Long), Alaska. The sampled peat layer underlies $8 \mathrm{ft}$ of peat and overlies $10 \mathrm{ft}$ of sand, which in turn overlies 6 to $10 \mathrm{ft}$ of Bootlegger Cove clay and 20 to $30 \mathrm{ft}$ of tan silt at the base. Coll. 1956 and subm. by R. D. Miller, E. Dobrovolny, and W. R. Hansen, U. S. Geological Survey, Denver, Colorado.

\section{W-800. Lituya Bay, Alaska}

$6060 \pm 200$

Stump rooted in place in forest-peat layer and sheared off at contact with overlying till. Exposed in near-vertical cliff cut in surficial deposit by the 1958 giant wave, SE shore of Lituya Bay, ca. $200 \mathrm{ft}$ back from high-tide line, and $1.7 \mathrm{mi} \mathrm{N} 76^{\circ} \mathrm{E}$ of Harbor Point (58 $39^{\prime} \mathrm{N}$ Lat, $137^{\circ} 36^{\prime} \mathrm{W}$ Long), Mount Fairweather Quadrangle, Alaska. Stump was sheared during last advance of ice to mouth of Lituya Bay. Location is near the end moraine; date is thus close to culmination of the last advance of the Lituya Bay lobe. Coll. 1958 and subm. by D. J. Miller, U. S. Geological Survey, Menlo Park, California.

\section{W-568. Nadina, SE Copper River Basin, Alaska $\quad 9000 \pm 400$}

Peat and twigs from thin bed beneath $12 \mathrm{ft}$ of pond silt and clay, alluvial sand and gravel, and eolian sand capping a 150-ft bluff on the Nadina River $\left(61^{\circ} 56^{\prime} 20^{\prime \prime} \mathrm{N}\right.$ Lat, $144^{\circ} 55^{\prime} 30^{\prime \prime} \mathrm{W}$ Long), Alaska. Sample overlies silty and sandy lacustrine deposits that cap $25 \mathrm{ft}$ of contorted outwash and till laid down during the last major glaciation. Till from an earlier glaciation lies at the base of the bluff. Coll. 1956 and subm. by D. R. Nichols, U. S. Geological Survey, Washington, D. C. Comment: sample provides a minimum age of withdrawal of the ice from this area and for lowering below $2250 \mathrm{ft}$ the lake 
which occupied large parts of the Copper River basin during the last major glaciation.

\section{W-569. Raft Creek, Upper Susitna River, Alaska $2030 \pm 400$}

Log (spruce) from peat bed $11 \mathrm{ft}$ above the base of a 35 - $\mathrm{ft}$ section of steeply dipping frozen sand and gravel exposed in a cutbank of Raft Creek, tributary to the Susitna River ( $63^{\circ} 01^{\prime} 10^{\prime \prime} \mathrm{N}$ Lat, $147^{\circ} 18^{\prime} 00^{\prime \prime} \mathrm{W}$ Long), Alaska. From lowermost of three peat beds and directly overlies a thin but widespread volcanic ash. Coll. 1954 by D. R. Nichols; subm. by D. M. Hopkins, U. S. Geological Survey, Washington, D. C. Comment: collected as a check on W.62, $1100 \pm 200$ (USGS I). Both samples were assumed to have been deposited in pitted outwash behind a large moraine formed during the last major glaciation. The sand and gravel are now believed to record a period of alluviation accompanied by volcanism. Permafrost subsequently has invaded these materials, forming ice masses which have melted out in part, leaving a highly pitted surface.

\section{W-674. Upper Susitna River, Alaska}

$\mathbf{2 0 0 0} \pm \mathbf{2 0 0}$

Log imbedded in middle of deposits forming a persistent 13-ft terrace on $\mathbb{W}$ bank of the Susitna River, $5 \mathrm{mi}$ above the mouth of the Maclaren River $\left(62^{\circ} 54^{\prime} 20^{\prime \prime} \mathrm{N}\right.$ Lat, $147^{\circ} 07^{\prime} 45^{\prime \prime} \mathrm{W}$ Long), Alaska. The terrace deposits above river level consist of: horizontally bedded sandy gravel, $5.5 \mathrm{ft}$; torrentially bedded silts and sands, $2.5 \mathrm{ft}$, in which the sample, and numerous twigs and peaty balls occur; and horizontally and torrentially cross-bedded clayey silt, 5 ft. Coll. 1953 and subm. by D. R. Nichols, U. S. Geological Survey, Washington, D. C. Comment: terrace is constructional; it records a period of strong alluviation occurring on the Susitna River and its tributaries (W-569, this list) and may be correlative with a post-Hypsithermal glacial advance in the nearby mountains.

\section{W-717. Tolsano, SE Copper River basin, Alaska $6910 \pm 250$}

Peat from alluvial gravels in exposure near top of bluff on $\mathrm{E}$ side of Tolsona Creek, $25 \mathrm{mi} \mathrm{S}$ of Mile 172.5 Glenn highway $\left(62^{\circ} 05^{\prime} 30^{\prime \prime} \mathrm{N}\right.$ Lat, $145^{\circ} 57^{\prime} 50^{\prime \prime} \mathrm{W}$ Long), Alaska. Peat bed is infolded with medium gravels lying above and below the peat. Undisturbed, horizontally bedded sand and peat overlie and truncate the gravel. All are perennially frozen and overlie light-gray, lacustrine, clayey silt with large ice masses. Coll. 1954 and subm. by D. R. Nichols, U. S. Geological Survey, Washington, D. C. Comment: sample provides a minimum date for draining of the Copper River lake and dates a period of alluviation preceding a cold period during which permafrost invaded the gravels, and growth of ground ice contorted the bedding. Dating of peat in the upper sands will more closely bracket this cold period, which
formed the permafrost.

\section{W-830. Little Tonsina, SE Copper River Basin, Alaska}

Log (spruce), 3 in. in diam., from 6-ft exposure in a frost mound in the Little Tonsina River valley, $.5 \mathrm{mi} W$ of Mile 69 Richardson highway $\left(61^{\circ}\right.$ $31^{\prime} 05^{\prime \prime} \mathrm{N}$ Lat, $145^{\circ} 14^{\prime} 18^{\prime \prime}$ W Long), Alaska. Sample lay in an organic silt 
zone, overlying $21 \mathrm{in}$. of medium gray, silty sand, and overlain by $22 \mathrm{in}$. of silty, fine sand, and $28 \mathrm{in}$. of alternating woody, organic silt. Mound was being destroyed by thawing and expansion of a small pond at the base. Coll. 1958 and subm. by D. R. Nichols, U. S. Geological Survey, Washington, D. C. Comment: sample dates a period of subaerial plant growth that interrupted periods of lake or pond deposition. With cessation of lake conditions, permafrost has invaded the ground and formed large ground-ice masses and frost mounds.

W-844. Chitina, SE Copper River basin, Alaska $6330 \pm 240$

Twigs from base of $20-\mathrm{ft}$ section of eolian silt and sand capping a $200-\mathrm{ft}$ bluff at the confluence of the Copper and Chitina Rivers, Chitina $\left(61^{\circ} 31^{\prime} 10^{\prime \prime}\right.$ $\mathrm{N}$ Lat, $144^{\circ} 23^{\prime} 30^{\prime \prime} \mathrm{W}$ Long), Alaska. The silt and sand also include shells of modern snail forms, charcoal particles, compressed wood, and discontinuous thin peaty zones. The eolian deposits overlie unconformably $180 \mathrm{ft}$ of massive till. Coll. 1955 and subm. by D. R. Nichols, U. S. Geological Survey, Washington, D. C. Comment: sample probably closely postdated the commencement of incision of the Copper River drainage into the basin surface after withdrawal of ice from the lower part of the Copper River and draining of the lake formed in the Copper River basin during the last major glaciation.

W-846. Tonsina, SE Copper River basin, Alaska

Sample cut from basal portion of multi-root system of a buried stump (white (?) spruce) near top of $200-\mathrm{ft}$ bluff on the $\mathrm{S}$ side of the Tonsina River, $5.5 \mathrm{mi}$ above its mouth (61 $42^{\prime} 25^{\prime \prime} \mathrm{N}$ Lat, $145^{\circ} 01^{\prime} 20^{\prime \prime} \mathrm{W}$ Long), Alaska. Basal root lies $3 \mathrm{ft}$ below the surface and just below the top of a 2 - $\mathrm{ft}$ bed of silty sand on which an 18-in. soil profile has been developed. Eight root levels at the base of the stump are buried in $2.5 \mathrm{ft}$ of eolian silt and sand which overlie the soil profile. Underlying the silty sand is $150 \mathrm{ft}$ of sand and coarse gravel (probably deltaic). A modern, mature white spruce forest is growing at the top of the bluff. Coll. 1955 and subm. by D. R. Nichols, U. S. Geological Survey, Washington, D. C. Comment: date, although it would be a minimum for withdrawal of the Copper River lake from the delta and the 1600 -ft strandline, appears much too young from a review of the field relations. Thus it is assumed that contamination of the basal root before, during, or after collection, by unknown means, has resulted in an anomalous date.

\section{W-831. Central Kobuk River valley, Alaska}

$>33,000$

Silty peat collected $102 \mathrm{ft}$ down from top of $110-\mathrm{ft}$ bluff on $\mathrm{S}$ side of Kobuk River, W of mouth of Ambler River (67 $05^{\prime} \mathrm{N}$ Lat, $158^{\circ} 10^{\prime} \mathrm{W}$ Long), Alaska. Bluff exposes from top to bottom: $10 \mathrm{ft}$ tan eolian sand; $65 \mathrm{ft}$ grayish eolian sand; $35 \mathrm{ft}$ mixed organic and sandy material. Date serves as a reference point in chronology of the eolian deposits of the central Kobuk valley. Coll. 1952 and subm. by A. T. Fernald and D. R. Nichols, U. S. Ceological Survey, Washington, D. C.

W-841. Upper Kobuk River valley, Alaska $\quad \mathbf{5 2 7 0} \pm \mathbf{2 4 0}$

Tree branches collected $13 \mathrm{ft}$ down from top of 20 -ft terrace bluff along $\mathrm{E}$ side of Beaver Creek, a tributary of the Kobuk River $\left(66^{\circ} 52^{\prime} \mathrm{N}\right.$ Lat, $155^{\circ}$ 
$02^{\prime} \mathrm{W}$ Long), Alaska. Bluff exposes $2 \mathrm{ft}$ of peat over $18 \mathrm{ft}$ of rubbly gravel. Coll. 1952 and subm. by A. T. Fernald and D. R. Nichols, U. S. Geological Survey, Washington, D. C.

\section{W-573. Upper Matanuska Valley, Alaska}

$\mathbf{3 6 2 0} \pm \mathbf{2 5 0}$

Charcoal from cut on $\mathrm{N}$ side of Glenn highway at Mile 108.8 from Anchorage (Anchorage D-2 Quadrangle, U.S.G.S. $1: 63,360$ series) $\left(61^{\circ} 48^{\prime} 6^{\prime \prime}\right.$ $\mathrm{N}$ Lat, $147^{\circ} 37^{\prime} 06^{\prime \prime} \mathrm{W}$ Long), Alaska. From organic-rich pods in lower of two soil profiles separated by volcanic ash and buried by $4 \mathrm{ft}$ of angular alluvial-fan or talus gravel from adjoining steep southern slope of Sheep Mountain. Buried soils overlie well-rounded cobble-boulder outwash gravel. Coll. 1954 and subm. by J. R. Williams and O. J. Ferrians, Jr., U. S. Geological Survey, Washington, D. C.

\section{W-583. Blue Lake, Alaska}

$13,280 \pm 400$

Basal peat, $3 \mathrm{ft}$ below surface in bank at $\mathrm{S}$ end of Blue Lake (Gulkana A-6 Quadrangle, U.S.G.S. 1:63,360 series), $3.7 \mathrm{mi} N 48^{\circ} \mathrm{W}$ of Bench Mark Mend $\left(62^{\circ} 12^{\prime} 42^{\prime \prime} \mathrm{N}\right.$ Lat, $146^{\circ} 58^{\prime} 00^{\prime \prime} \mathrm{W}$ Long), Alaska. Dated sample provides minimum age for outwash gravel exposed at base of cut. The locality lies in outwash channel leading from morainal ridge $0.7 \mathrm{mi} \mathrm{S}$ to broad fan or delta near former margin of 2450-ft lake 1.5 to $2 \mathrm{mi} \mathrm{NNE}$. Coll. 1954 and subm. by J. R. Williams and O. J. Ferrians, Jr., U. S. Geological Survey, Washington, D. C.

\section{W-715. Nelchina River, Alaska}

$4200 \pm 200$

Peaty sand from near top of $\mathrm{N}$ bank, $200 \mathrm{ft}$ high, of Nelchina River, 0.8 $\mathrm{mi} \mathrm{S} 40^{\circ} \mathrm{E}$ of Mile 143, Glenn highway (from Anchorage) (Valdez D-8 Quadrangle, U.S.G.S. 1:63,360 series) $\left(61^{\circ} 58^{\prime} 48^{\prime \prime} \mathrm{N}\right.$ Lat, $146^{\circ} 45^{\prime} 30^{\prime \prime} \mathrm{W}$ Long), Alaska. From lowest of several closely spaced, contorted peat beds, 3 $\mathrm{ft}$ below top of $8 \mathrm{-ft}$ sand unit. This unit lies beneath $1.5 \mathrm{ft}$ of surface peat and cliff-head eolian sand and overlies silty till. Coll. 1957 and subm. by J. R. Williams and L. Chase, U. S. Geological Survey, Washington, D. C.

\section{W-767. Little Nelchina River, Alaska $\quad 10,250 \pm 250$}

Peat from cut ca. $75 \mathrm{ft} \mathrm{N}$ of E abutment of Little Nelchina River bridge, Mile 137.5, Glenn highway (from Anchorage) (Valdez D-8 Quadrangle, U.S.G.S. $1: 63,360$ series $)\left(61^{\circ} 59^{\prime} 18^{\prime \prime}\right.$ N Lat, $146^{\circ} 56^{\prime} 42^{\prime \prime}$ W Long), Alaska. From two closely spaced peat bands that form part of buried soil developed on terrace alluvium washed from nearby walls of Little Nelchina canyon. Coll. 1954 and subm. by J. R. Williams and O. J. Ferrians, Jr., U. S. Geological Survey, Washington, D. C. Comment: sample provides minimum age for a glacial retreat at this site, for cutting of Little Nelchina canyon, and for subjacent terrace alluvium.

\section{W-842. Nelchina, SE Copper River basin, Alaska}

Organic silty sand, hard and jointed, taken from $\mathrm{S}$ bank, $200 \mathrm{ft}$ high, Nelchina River (Valdez Quadrangle, U.S.G.S. 1:63,360 series) (61 $59^{\prime} 48^{\prime \prime}$ $\mathrm{N}$ Lat, $146^{\circ} 40^{\prime} 42^{\prime \prime} \mathrm{W}$ Long), Alaska. From beneath $10 \mathrm{ft}$ of surficial lacustrine silt or clay which overlies ca. $50 \mathrm{ft}$ of poorly exposed till, silt, sand, and alluvial deposits. Sample horizon overlies coarse blue-gray gravel which in 
this section overlies gravelly glacial deposits and shale. Downstream, the coarse gravel overlies lacustrine deposits dated $>38,000 \mathrm{yr}$ (W-295, USGS II). Coll. 1957 and subm. by J. R. Williams and L. Chase, U. S. Geological Survey, Washington, D. C.

\section{Point Possession bog series, Kenai Lowland, Alaska}

Wood from sea bluff section ca. $1 \mathrm{mi}$ SE of Point Possession $\left(61^{\circ} 02^{\prime} \mathrm{N}\right.$ Lat, $150^{\circ} 21^{\prime} \mathrm{W}$ Long), Kenai Lowland, Alaska, exposing a bog (coll. no. D-1) buried beneath 30 to $50 \mathrm{ft}$ of sand (predominantly cliff-head dune sand). Bog sediments consist of a moss peat unit, 5 to $10 \mathrm{ft}$ thick, and a base of 3 to $4 \mathrm{ft}$ of pond sediments. Underlying the bog are 20 to $30 \mathrm{ft}$ of blue-gray proglacial lake stony silt of Naptowne age, which overlies 40 to $50 \mathrm{ft}$ of weathered buff drift of Knik age. Samples taken from the top and bottom of a 1 -ft zone of woody peat with sand layers at the base of the moss peat unit, and also from a stratified sand layer in the overlying sands. A previously analyzed sample, W-474 (USGS IV), taken from the basal $\mathrm{ft}$ of the pond sediments was dated at $10,370 \pm 350$. The geology of the area is described by the collector in a U. S. Geological Survey report now in process (Karlstrom, in preparation). Coll. 1954 and subm. by T. N. V. Karlstrom, U. S. Geological Survey, Washington, D. C.

W-838. Point Possession bog, sand layer $\quad 1530 \pm 200$ Log collected ca. $12 \mathrm{ft}$ above top of moss peat unit in the overlying sands. W-603. Point Possession bog, top of woody peat $8640 \pm 280$ Wood from the top of the 1-ft zone of woody peat.

W-602. Point Possession bog, base of woody peat

$$
8420 \pm 300
$$

Wood from base of the 1-ft zone of woody peat. The apparent inversion of ages for this narrow zone is not disturbing, as the age difference is explainable by the counting errors quoted.

W-644. Goose Bay, Knik Arm, Alaska

Wood from sea bluff section exposed along W shore of Knik Arm near Goose Bay (61 $24^{\prime} \mathrm{N}$ Lat, $149^{\circ} 50^{\prime} \mathrm{W}$ Long), Alaska. From base of advance outwash overlying lignitized peat layer and drift of Knik age and overlain by till of Naptowne age. The geology of the area is described in a U. S. Geological Survey report now in process (Karlstrom, in preparation). Coll. 1957 and subm. by T. N. V. Karlstrom, U. S. Geological Survey, Washington, D. C.

W-748. Salamato Creek, Kenai Lowland, Alaska $13,500 \pm 400$

Peat from surface bog exposed in sea bluffs near Salamato Creek $\left(60^{\circ}\right.$ $37^{\prime} \mathrm{N}$ Lat, $151^{\circ} 21^{\prime}$ W Long), Kenai Lowland, Alaska. Sample of silty peat with twigs was collected from base of organic lake sediments unconformably overlying contorted weathered sand and gravel of Knik age. The geology of the area is described in a U. S. Geological Survey report now in process (Karlstrom, in preparation). Coll. 1958 and subm. by T. N. V. Karlstrom, U. S. Geological Survey, Washington, D. C.
W-559. Yakutat Bay, Alaska
$830 \pm 160$

Wood from lens of hluish-gray silt in sea cliff on ocean beach, $1.2 \mathrm{mi}$ SE 
of Ocean Cape at entrance of Yakutat Bay $\left(59^{\circ} 29^{\prime} \mathrm{N}\right.$ Lat, $139^{\circ} 55^{\prime} \mathrm{W}$ Long $)$, Alaska. The 4-in. lens is at $25 \mathrm{ft}$ altitude in hard gray till of the end moraine forming the western part of Phipps Peninsula and continuing across the mouth of Yakutat Bay as a submarine ridge. Coll. 1956 and subm. by J. H. Hartshorn, U. S. Geological Survey, Boston, Massachusetts.

\section{W-593. Sagavanirktok River, Alaska}

$1900 \pm 200$

Peat from bluff exposure in a ravine, tributary to the Sagavanirktok River $\left(69^{\circ} 45^{\prime} \mathrm{N}\right.$ Lat, $149^{\circ} 20^{\prime} \mathrm{W}$ Long), Alaska. From a 7 -in. layer overlying brown silt and in turn overlain by 16 in. of brown silt. Coll. 1956 by K. M. Hussey; subm. by H. W. Coulter, U. S. Geological Survey, Washington, D. C.

\section{Tiekel River series, Alaska}

Equisetum spp. stems from a fresh roadcut in the Tiekel River valley, at Mile 6l, Richardson highway $\left(61^{\circ} 26^{\prime} \mathrm{N}\right.$ Lat, $145^{\circ} 7^{\prime} \mathrm{W}$ Long), Alaska. Samples of horsetail stems were in growth position in cross-bedded silt overlain by $30 \mathrm{ft}$ of coarse channel gravel. Graphic reconstruction of cut indicated that locus of horsetail stems could not have been less than $15 \mathrm{ft}$ from original surface; hence they were believed to date the enclosing silt. To check the date obtained on the first sample, a new sample was collected and run, with the same results. Subsequent investigation of Equisetum spp. growing in comparable localities indicates that horizontal projection of root systems of up to $15 \mathrm{ft}$ along bedding planes in silt, with downward projection of vertical tap roots several ft in length, is not uncommon. Coll. 1958 and 1959 and subm. by H. W. Coulter, U. S. Geological Survey, Washington, D. C.

\section{W-766. Horsetails, 1958 coll. $\quad<200$ \\ W-854. Horsetails, 1959 coll. $\quad<200$}

\section{W-839. Umiat, Alaska}

$1060 \pm 200$

Peat from test pit on a ridge top $2 \mathrm{mi} \mathrm{NNW}$ of Umiat airstrip $\left(69^{\circ} 23^{\prime}\right.$ $\mathrm{N}$ Lat, $152^{\circ} 11^{\prime} \mathrm{W}$ Long), Alaska. From a 0.5 -in. layer overlying brown silt and in turn overlain by 4.5 in. of gray silt and $18.5 \mathrm{in}$. of brown silt. Coll. 1955 and subm. by H. W. Coulter, U. S. Geological Survey, Washington, D. C.

\section{W-847. Footprint Lake, Alaska}

$9100 \pm 260$

Peat from test pit in an artificially drained lake bed (Footprint Lake), $4 \mathrm{mi} \mathrm{SSW}$ of the Arctic Research Laboratory, Barrow $\left(71^{\circ} 15^{\prime} \mathrm{N}\right.$ Lat, $156^{\circ}$ $45^{\prime} \mathrm{W}$ Long), Alaska. From a layer 44 in. below the surface of the lacustrine sequence. Sample came from 32 in. below the buried peat of sample W-432, $3540 \pm 300$ (USGS IV). Coll. 1956 by K. M. Hussey; subm. by H. W. Coulter, U. S. Geological Survey, Washington, D. C.

\section{W-531. Gakona, NE Copper River basin, Alaska}

Wood fragments from a bluff on $\mathrm{W}$ side of the Copper River, .75 mi below the mouth of the Gakona River (Gulkana B-3 Quadrangle, U.S.G.S. $1: 63,360$ series $)\left(62^{\circ} 18^{\prime} \mathrm{N}\right.$ Lat, $145^{\circ} 19^{\prime} \mathrm{W}$ Long $)$, Alaska. Altitude of sample is ca. $1515 \mathrm{ft}$. The stratigraphic section, from the base upward, consists of: $15 \mathrm{ft}$ of till-like material; $30 \mathrm{ft}$ of coarse gravel grading upward into fine sand, with included wood fragments (this sample); $10 \mathrm{ft}$ of poorly laminated 
silt with interspersed pebbles and cobbles; $15 \mathrm{ft}$ of gravelly silt (till-like) ; $5 \mathrm{ft}$ of coarse gravel; $15 \mathrm{ft}$ of fine, silty sand with interbedded organic material. Stratigraphy suggests that the wood fragments were buried near the end of a fluvial cycle which preceded glacio-lacustrine deposition of poorly laminated silt near the beginning of the last major glaciation in the area (Ferrians and Schmoll, 1957). This silt appears to grade upward into gravelly silt (till-like) that suggests either a near-ice or an ice environment of deposition. The gravelly silt is unconformably overlain by coarse gravel deposited in an abandoned river channel higher than those of the present river system. Cliff-head dune deposits mantle the bluff at the upper surface. Coll. 1956, subm., and interpreted by O. J. Ferrians, Jr., and H. R. Schmoll, U. S. Geological Survey, Washington, D. C.

W-592. Chistochina, NE Copper River basin, Alaska $850 \pm 200$

Wood from dry well dug behind motel unit at Chistochina Trading Post, Mile 32.9, Tok Cutoff portion of Glenn highway (Gulkana C-2 Quadrangle, U.S.G.S. 1:63,360 series) (62 $34^{\prime} \mathrm{N}$ Lat, $144^{\circ} 40^{\prime} \mathrm{W}$ Long), Alaska. The wood lies in medium- to coarse-grained gravel and sand, $4 \mathrm{ft}$ beneath the surface of the extensive 10-ft terrace of the Copper River. Coll. 1956, subm., and interpreted by O. J. Ferrians, Jr., and H. R. Schmoll, U. S. Geological Survey, Washington, D. C. Comment: sample provides a date within the last significant period of stream agradation in the area (a minor glacial episode), prior to a period of general degradation to present stream grade (relative deglaciation).

\section{W-714. Northeastern Copper River basin, Alaska $\quad 9400 \pm 300$}

Peat from near top of bluff on $\mathrm{W}$ side of the Gakona River, $0.3 \mathrm{mi}$ upstream from its mouth (Gulkana B-3 Quadrangle, U.S.G.S. 1:63,360 series) $\left(62^{\circ} 18^{\prime} \mathrm{N}\right.$ Lat, $145^{\circ} 18^{\prime} \mathrm{W}$ Long), Alaska. Altitude of peat bed is ca. 1730 $\mathrm{ft}$. The straigraphic section includes, from river level upward: $240 \mathrm{ft}$ covered; $80 \mathrm{ft}$ of lacustrine deposits (interbedded gravelly sandy silt, silt, sand, and gravel; and poorly bedded silt with scattered stones); $1.5 \mathrm{ft}$ of interbedded peat and eolian sand (this sample is from the lowest peat bed) ; $6 \mathrm{ft}$ of eolian sand generally lacking organic material; $1.2 \mathrm{ft}$ of interbedded peat, wood fragments, and eolian sand; $4 \mathrm{ft}$ of eolian sand with scattered organic frag. ments; and $3 \mathrm{ft}$ of eolian sand with numerous included wood fragments and peat beds. Coll. 1957, interpreted, and subm. by O. J. Ferrians, Jr., and H. R. Schmoll, U. S. Geological Survey, Washington, D. C. Comment: sample dates the initiation of eolian deposition at this site and provides a minimum age older than that previously obtained for the final withdrawal of the regional lake in the Copper River basin from this elevation (Ferrians and Schmoll, 1957). The deposition of the eolian sand suggests a time of river agradation and relative glaciation that followed the period of relative deglaciation during which the lake withdrew, the river incised itself beneath the former lake floor, and peat growth occurred.

W-843. Sanford, NE Copper River basin, Alaska $31,300 \pm 1000$

Peat from bluff on $\mathrm{N}$ side of the Sanford River, ca. $11 \mathrm{mi}$ upstream from its mouth (Gulkana B-2 Quadrangle, U.S.G.S. 1:63,360 series) $\left(62^{\circ} 16^{\prime} \mathrm{N}\right.$ 
Lat, $144^{\circ} 58^{\prime} \mathrm{W}$ Long), Alaska. Alititude of peat bed is ca. $2120 \mathrm{ft}$. The stratigraphic section includes, from river level upward: $35 \mathrm{ft}$ of gravel; $90 \mathrm{ft}$ of interbedded fine- to medium-grained sand and silt, with some gravel horizons, and near the base of this unit, several peat beds, the lowest of which was sampled; $15 \mathrm{ft}$ of fine silty sand with stones and interbedded gravel; 10 to 30 ft of eolian sand. Coll. 1958, interpreted, and subm. by O. J. Ferrians, Jr., and H. R. Schmoll, U. S. Ceological Survey, Washington, D. C. Comment: sample dates a time when regional lake level in the Copper River basin (Ferrians and Schmoll, 1957) was fluctuantly rising from below the 2120-ft level (deposition of the alluvial and deltaic gravel at the base of the section) to levels above this elevation (deposition of material overlying the sampled and related peat beds). This rise of lake level was either a slow rise during the earlier part of the last major glaciation in the area, in progress from some time prior to 38,000 B.P. (see W-531, this list), or followed a major recession occurring within the last major glaciation. Sample also indicates that glacier ice did not occupy this part of the Copper River basin since some time considerably prior to 31,000 B.P.

W-848. Twelvemile, NE Copper River basin, Alaska $11,390 \pm 300$

Peat from bluff on $\mathrm{E}$ side of the Gulkana River, $2.5 \mathrm{mi} \mathrm{S} 25^{\circ} \mathrm{E}$ of the mouth of Twelvemile Creek (Gulkana D-4 Quadrangle, U.S.G.S. 1:63,360 series) $\left(62^{\circ} 47^{\prime} \mathrm{N}\right.$ Lat, $145^{\circ} 37^{\prime} \mathrm{W}$ Long $)$, Alaska. Altitude of peat bed is ca. $2475 \mathrm{ft}$. The stratigraphic section includes, from river level upward: $5 \mathrm{ft}$ covered; $10 \mathrm{ft}$ of medium-grained sand, well bedded; $15 \mathrm{ft}$ of laminated silt and clay; $0.4 \mathrm{ft}$ of peat, with included twigs (this sample from upper $0.2 \mathrm{ft}$ ) ; $3 \mathrm{ft}$ of bedded silt and clay; and $3 \mathrm{ft}$ of peat, including modern surface. Coll. 1958, interpreted, and subm. by O. J. Ferrians, Jr., and H. R. Schmoll, U. S. Geological Survey, Washington, D. C. Comment: dated peat bed represents a fluctuation in the level of the lake in which the underlying and overlying silt and clay were deposited. This lake probably formed when flow of the Gulkana River was impeded by morainal deposits and before the river cut its present gorge through bedrock a short distance downstream. Sample dates the time of return of lake level to an elevation higher than that of the peat bed. Sample also indicates that glacier ice had retreated from this part of the Gulkana valley considerably prior to 11,390 B.P.

\section{Fish Lake series, Alaska}

Peat from cut bank in terrace on $\mathrm{N}$ side of West Fork of the Gulkana River, ca. $1.5 \mathrm{mi}$ upstream from the mouth of the small stream that drains Fish Lake (Gulkana C-4, Quadrangle, U.S.G.S. 1:63,360 series), northeastern Copper River Basin ( $62^{\circ} 36^{\prime} \mathrm{N}$ Lat, $145^{\circ} 52^{\prime} \mathrm{W}$ Long), Alaska. The stratigraphic section includes, from river level upward: $10 \mathrm{ft}$ of bedded silt, largely covered but probably of alluvial origin; $2 \mathrm{ft}$ of peat, including also twigs, especially in its upper part (W-806 from lowest 2 in., W-809 from highest 2 in.) ; $8 \mathrm{ft}$ of coarse alluvial sand; and $2 \mathrm{ft}$ of fine sand and silt (floodplain deposits) overlain by vegetation mat (largely peat) forming present surface of terrace. Coll. 1958, subm., and interpreted by O. J. Ferrians, Jr., and H. R. Schmoll, U. S. Geological Survey, Washington, D. C. Comment: samples date the beginning 
and end of a period of peat deposition preceded and followed by periods of alluviation. Dates also provide a measure of the rate of peat accumulation at this section.
W-809. Top of peat
$8000 \pm 300$
W-806. Base of peat
$\mathbf{8 7 2 0} \pm \mathbf{3 0 0}$

\section{Robertson River series, Alaska}

Wood and peat from bluff on $\mathrm{N}$ side of the Robertson River, ca. 900 $\mathrm{ft}$ from the mouth of the river $\left(66^{\circ} 30^{\prime} \mathrm{N}\right.$ Lat, $143^{\circ} 49^{\prime} \mathrm{W}$ Long $)$, Alaska. The bluff is $\mathrm{S}$ of the Alaska Highway near the old tracks of the former Alaska Highway. The Robertson River is 27 highway mi NW of Tok Junction. Section consists, from top to base, of: peat, $5.0 \mathrm{ft}$; gravel with peat matrix, $1.3 \mathrm{ft}$; peat, $2.5 \mathrm{ft}$; silt, mottled, $1.0 \mathrm{ft}$; sand, fine, brown, $3.0 \mathrm{ft}$; till, gray weathered, to base, $20 \mathrm{ft}$. Coll. 1957 and subm. by G. W. Holmes, U. S. Geological Survey, Washington, D. C.

\section{W-756. Robertson River, top peat layer $\quad 4250 \pm 250$}

Peat from the bottom $0.5 \mathrm{ft}$ of the top 5 -ft-thick peat layer.

W-753. Robertson River, gravel layer $\quad 5650 \pm 200$

Log from base of gravel layer.

W-859. Sheep Creek, Alaska

$\mathbf{5 9 4 0} \pm \mathbf{2 5 0}$

Root of spruce broken off from stump in $\mathrm{W}$ wall of placer cut, Sheep Creek, near Fairbanks, in $\mathrm{SE} 1 / 4$ sec. $17, \mathrm{~T} 1 \mathrm{~N}, \mathrm{R} 2 \mathrm{~W}\left(64^{\circ} 55^{\prime} \mathrm{N}\right.$ Lat, $148^{\circ}$ $00^{\prime}$ W Long), Fairbanks D-2 Quadrangle, Alaska. From ca. $5 \mathrm{ft}$ below surface of a gravel fan interbedded in a great silt deposit representing perhaps the last third of the Quaternary Period. The gravel overlies the Wisconsin-age Goldstream muck formation (or is part of the upper part) and is perennially frozen. Coll. 1956 and subm. by T. L. Péwé, U. S. Geological Survey, College, Alaska.

\section{W-736. Galena, Alaska}

$\mathbf{7 7 4 0} \pm \mathbf{2 0 0}$

Wood from cut bank of Yukon River, $\mathrm{N}$ bank, 6 mi upstream from Galena $\left(64^{\circ} 39^{\prime} \mathrm{N}\right.$ Lat, $156^{\circ} 59^{\prime} \mathrm{W}$ Long), Alaska. Wood at $4 \mathrm{ft}$ depth came from base of unconformity between "wet" permafrost with ice wedges and overlying "dry" frozen ground. Coll. 1954 and subm. by T. L. Péwé, U. S. Geological Survey, College, Alaska.

\section{W-196. Taylor, Alaska}

Plant material in block of silt exposed in gravel pit on road from Bunker Hill to Taylor, $0.3 \mathrm{mi} \mathrm{S}$ of Quartz Creek bridge $\left(65^{\circ} 20^{\prime} \mathrm{N}\right.$ Lat, $164^{\circ} 40^{\circ} \mathrm{W}$ Long), Seward Peninsula, Alaska. The silt block is enclosed in sandy gravel (Kougarok) underlying 10 to $25 \mathrm{ft}$ of late Quaternary windblown silt. Coll. 1950 and subm. by D. M. Hopkins, U. S. Geological Survey, Menlo Park, California.

\section{W-732. Eureka Creek, Alaska}

Wood from wall of Johnson and Isaacson gold-placer mine, Eureka Creek, Hot Springs District (65 $13^{\prime} \mathrm{N}$ Lat, $150^{\circ} 12^{\prime} \mathrm{W}$ Long), Tanana A-1 Quadrangle, Alaska. Sample enclosed in peaty silt containing evidence of a climate colder than at present. Subsequently a sheet of gravel covered the silt at a 
time when the climate was warmer; ice-wedges in the silt thawed out, and the resulting trenches were filled with wedges of gravel. Still later, the climate chilled again, and the silt and gravel again became perennially frozen. The collector believes that the peaty silt accumulated during early Wisconsin time and that the thawing of the ice-wedges and deposition of the gravel took place during a mid-Wisconsin warm interval. Coll. 1956 and subm. by D. M. Hopkins, U. S. Geological Survey, Menlo Park, California.

W-733. Sullivan Creek, Alaska

$6820 \pm 200$

Large, beaver-chewed log from wall of deep ditch draining Sullivan goldplacer pit, Sullivan Creek, Hot Springs District $\left(65^{\circ} 05^{\prime} \mathrm{N}\right.$ Lat, $150^{\circ} 54^{\prime} \mathrm{W}$ Long), Tanana A-2 Quadrangle, Alaska. The fossil beaver dam was covered by $5 \mathrm{ft}$ of massive yellow silt (reworked loess) and underlain by $10 \mathrm{ft}$ of wellbedded organic silt in which the wood was small, flattened, and poorly preserved. Well-preserved large wood is widely distributed at the level of the beaver dam; the wood horizon is believed by the collector to represent the Hypsithermal. The underlying peaty silt is thought to be of late Wisconsin age. Coll. 1956 and subm. by D. M. Hopkins. U. S. Geological Survey, Menlo Park, California.

\section{W-810. Snake River, Alaska}

Shells from marine gravel representing elevated barrier bar of Second Beach age; overlies end moraine of Nome River age. Section located at E end of ridge separating Snake River from Bering Sea $\left(64^{\circ} 31^{\prime} \mathrm{N}\right.$ Lat, $165^{\circ} 26^{\prime} \mathrm{W}$ Long), Nome C-1 Quadrangle, Alaska. Coll. 1956 and 1957 and subm. by D. M. Hopkins, U. S. Geological Survey, Menlo Park, California. Comment: sample should date period when sealevel stood between 25 and $50 \mathrm{ft}$ above its present position and should establish a minimum age for the Nome River glaciation.

\section{E. Canada}

\section{W-523. Steep Rock Lake, Ontario, Canada}

Wood from bank of recharge stream in the NE corner of Falls Bay, Steep Rock Lake, Steep Rock mine coordinates 32500 N, 31500 E ( $48^{\circ} 50^{\prime}$ N Lat, $91^{\circ} 40^{\prime} \mathrm{W}$ Long), Canada. Wood came from clay $5 \mathrm{ft}$ below contact with overlying gravel. Coll. 1956 by A. T. Broderick; subm. by H. L. James, U. S. Ceological Survey, Menlo Park, California.

\section{W-546. Grindstone Island, Canada}

Wood from base of peat bog being eroded by the sea $\mathrm{S}$ of Hospital Cape, W coast of Grindstone Island, Magdalen Islands, Gulf of St. Lawrence $\left(47^{\circ}\right.$ $22^{\prime} \mathrm{N}$ Lat, $61^{\circ} 57^{\prime} \mathrm{W}$ Long), Canada. From base of sphagnum bog, $3 \mathrm{ft}$ thick. The peat is topped by windblown sand and underlain by $2 \mathrm{ft}$ of sand resting on the sandstone bedrock. Coll. 1954 and subm. by V. K. Prest, Geological Survey of Canada, Ottawa. Comment: sample should date time of peat formation following period of marine overlap.

W-547. Alright Island, Canada

Wood from between two sand layers that mantle steep hill on Basse Point, 
Alright Island, Magdalen Islands, Gulf of St. Lawrence $\left(47^{\circ} 24^{\prime} \mathrm{N} \mathrm{Lat}, 61^{\circ}\right.$ 48' W Long), Canada. Carbonaceous layer, 1 to 3 in. thick, lies between two sand horizons 2 to $3 \mathrm{ft}$ thick on bedrock hill of sandstone. It was hoped the sample would date an interstadial period, a time of vegetal growth and stabilization of the hillside. Coll. 1954 and subm. by V. K. Prest, C,eological Survey of Canada, Ottawa.

\section{Fort Garry series, Manitoba, Canada}

Wood recovered from a vertical shaft for the Greater Winnipeg Water District aqueduct under the Red River, on the W bank, ca. $2400 \mathrm{ft} \mathrm{N} 55^{\circ} \mathrm{E}$ of junction of Pembina highway (Provincial Trunk highway 75) and University Crescent in municipality of Fort Garry (49 $48^{\prime} \mathrm{N}$ Lat, $97^{\circ} 12^{\prime} \mathrm{W}$ Long). Manitoba, Canada. From clayey silt, just above a bouldery till. Wood id. by the Forest Products Laboratory of the Canadian Dept. of Northern Affairs and National Resources. Coll. 1959 by W. Cornick and E. Leith, University of Manitoba, Winnipeg, Canada; subm. by Leith on suggestion by J. Elson.

\section{W-860. Populus balsamifera $L$.}

W-862. Fraxinus sp.

\section{F. Miscellaneous}

\section{W-749. Kibwezi, Kenya, Africa}

$6200 \pm 320$

$6750 \pm 320$

$480 \pm 200$

Charcoal from bore hole drilled near Kibwezi, $120 \mathrm{mi}$ SE of Nairobi $\left(2^{\circ}\right.$ $30^{\circ} \mathrm{S}$ Lat, $38^{\circ} 10^{\prime} \mathrm{E}$ Long), Kenya, Africa. From beneath a lava flow (the Limuru trachytes) and above a limestone deposited around a spring. Coll. 1957 by R. G. Dodson; subm. by A. O. Thompson, Mines and Geological Dept., Nairobi, Kenya.

\section{Brown Beach series, Kouali Point, Algeria}

Marine shells from Brown Beach, Kouali Point $\left(36^{\circ} 31^{\prime} \mathrm{N}\right.$ Lat, $2^{\circ} 15^{\prime} \mathrm{E}$ Long), Algeria. Brown Beach is a beach deposit, 70 to $90 \mathrm{~cm}$ thick, resting on continental material, 2 to $3 \mathrm{~m}$ above the present sealevel (Briggs, 1951). $\mathrm{O}^{16} / \mathrm{O}^{18}$ paleotemperature analyses of the shells have been made by $\mathrm{T}$. Mayeda. The possibility exists that the beach material may have been completely reworked by sea waves. Coll. 1956 by C. Stearns, Tufts College; subm. by Cesare Emiliani, University of Miami, Coral Gables, Florida.

\footnotetext{
W-658. Brown Beach shells, 0- to 10-cm level $3760 \pm 160$

W-659. Brown Beach shells, 40- to 50-cm level $3480 \pm 160$

W-851. McMurdo Sound, Antarctica $\quad 660 \pm 300$

Mummified seal carcass from Taylor Dry Valley $\left(77^{\circ} 42^{\prime} \mathrm{S}\right.$ Lat, $162^{\circ} 30^{\prime}$ E Long), McMurdo Sound, Antarctica. Seal is one of many found lying on the surface of the ground in various stages of preservation; in this case, $15 \mathrm{mi}$ from the sea (Péwé, Rivard, and Llano, 1959). Coll. 1957 by T. L. Péwé, N. Rivard, and G. A. Llano; subm. by Llano, National Academy of Sciences. Washington, D. C.
}

Mount Kosciusko series, Australia

Peat from sections in the Mount Kosciusko area, Australia, collected to give dates to various glacial events in the area (Browne, 1952). Coll. 1956 by A. B. Costin; subm. by E. D. Gill, National Museum of Victoria, Melbourne. 
W-768. Mount Kosciusko, no. 5

Basal sample of peat from Twynam snow patch $\left(36^{\circ} 24^{\prime} \mathrm{S}\right.$ Lat, $148^{\circ} 21^{\prime}$ E Long), Mount Kosciusko area, Australia. If there is a Little Ice Age represented, this sample should give its minimum age.

W-769. Mount Kosciusko, no. 1D

$8100 \pm 250$

Peat from lowest horizon in a sequence of peat and gravel filling an old lake formed during valley glaciation and not since ice-covered; at Perisher Lake $\left(36^{\circ} 25^{\prime} \mathrm{S}\right.$ Lat, $148^{\circ} 24^{\prime} \mathrm{E}$ Long), Mount Kosciusko area, Australia.

W-770. Mount Kosciusko, no. 9B

$4580 \pm 220$

Peat from below a sequence of peats and gravels in a cirque attributed to Cirque Glaciation age; at Club Lake ( $36^{\circ} 25^{\prime} \mathrm{S}$ Lat, $148^{\circ} 20^{\prime} \mathrm{E}$ Long), Mount Kosciusko area, Australia.

\section{W-780. Dashur, Egypt}

$2050+200$

Mummy wrappings from a mummified bull from Dashur $\left(29^{\circ} 50^{\prime} \mathrm{N}\right.$ Lat, $31^{\circ} 10^{\prime} \mathrm{E}$ Long), Egypt. The bull is in the National Museum in Washington, D. C. It was purported to date from the Late Ptolemaic-Early Roman period of 200 B.C. to A.D. 200. Sample was run to cross-check a new dating method utilizing the hydration rim on obsidian (the bull's eyes were made of obsidian). Subm. 1959 by I. Friedman, U. S. Geological Survey, Washington, D. C.

\section{W-705. Cancale, France}

$7580 \pm 250$

Peaty mud from depth of 1.3 to $1.7 \mathrm{~m}$ below sealevel at Plage Duguesclin, Cancale, on $\mathrm{S}$ end of Bay of Mont-Saint-Michel $\left(48^{\circ} 42^{\prime} \mathrm{N}\right.$ Lat, $1^{\circ} 50^{\prime} \mathrm{W}$ Long), Bretagne, France. From basal bed of the Lower Flandrian-age deposits. Coll. 1957 by J. Bourcart, The Sorbonne; subm. by P. E. Cloud, U. S. Geological Survey, Washington, D. C.

\section{Laacher See pumice series, Germany}

Charcoal embedded in mudflows in the Laacher See region, relating to the Laacher See pumice eruption. Coll. 1953 by Josef Frechen; subm. by E. A. Rosauer, Iowa State University, Ames.

W-525. Mayen, Western Germany

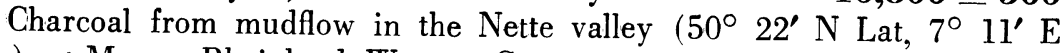
Long), at Mayen, Rheinland, Western Germany.

W-528. Andernack, Western Germany $11,150 \pm 200$

Charcoal from mudflow in the Brol valley $\left(50^{\circ} 26^{\prime} \mathrm{N}\right.$ Lat, $7^{\circ} 22^{\prime} \mathrm{E}$ Long), at Andernach, Rheinland, Western Germany.

\section{Nunatarssuag series, Greenland}

Moss and tundra plants from below the ice cap and from shear planes in the ice, at two localities in Greenland. Coll. 1956 and subm. by R. P. Goldthwait, Ohio State University, Columbus.

W-532. New tunnel, Greenland

Moss and tundra plants scraped from glacier bed on tunnel floor, ca. 100 $\mathrm{ft}$ back from Red Rock Ice Cliff at edge of glacier, under $140 \mathrm{ft}$ of ice, near Nunatarssuag $\left(76^{\circ} 55^{\prime} 13^{\prime \prime}\right.$ N Lat, $66^{\circ} 57^{\prime} 59^{\prime \prime}$ W Long), Greenland. 
W-537. Shear planes, Greenland

Moss from shear planes dipping back into North Ice Cap, $2 \mathrm{~km} \mathrm{E} \mathrm{of} \mathrm{Red}$ Rock Lake Camp, near Nunatarssuag $\left(76^{\circ} 55^{\prime} 13^{\prime \prime} \mathrm{N}\right.$ Lat, $66^{\circ} 56^{\prime} 00^{\prime \prime} \mathrm{W}$ Long), Greenland. Sample came from surface and near surface.

W-555. Kap Moltke, North Greenland

$5370 \pm 200$

Shells from marine clay terrace, $2 \mathrm{mi} \mathrm{NE}$ of Kap Moltke, E side of Brönlund Fjord ( $82^{\circ} 08^{\prime} \mathrm{N}$ Lat, $31^{\circ} 10^{\prime} \mathrm{W}$ Long), North Greenland. From the surface of the marine clay terrace at $40 \mathrm{ft}$ altitude. The clay is $20 \mathrm{ft}$ thick here and rests on a bedrock of shale and limestone; $10 \mathrm{ft}$ of moraine and outwash cover the terrace. Coll. 1956 and subm. by W. E. Davies, U. S. Geological Survey, Washington, D. C.

W-815. Newman Bay, Greenland

$3780 \pm 300$

Shells (Hiatella arctica, Astarte borealis) from coastal terrace cut into a gravel moraine on Newman Bay, 25 mi from its mouth, Polaris Promontory $\left(81^{\circ} 40^{\prime} \mathrm{N}\right.$ Lat, $59^{\circ} 05^{\prime} \mathrm{W}$ Long), Greenland. The moraine is deposited on a plain formed of marine clay-silt. Altitude of the coastal terrace where the shells were obtained is $40 \mathrm{ft}$. Coll. 1958 and subm. by W. E. Davies, U. S. Geological Survey, Washington, D. C.

\section{W-816. Polaris Promontory, Greenland}

$6100 \pm 300$

Shells (Hiatella arctica, Mya truncata) from Polaris Promontory $\left(81^{\circ}\right.$ $37^{\prime} \mathrm{N}$ Lat, $60^{\circ} 15^{\prime} \mathrm{W}$ Long), Greenland. The shells occur in a marine clay-silt at $268 \mathrm{ft}$ altitude. The clay-silt forms a broad plain, 10 to $15 \mathrm{mi}$ wide, crossing the Promontory from SW to NE. Samples obtained from the top $1 \mathrm{ft}$ of the deposit in the middle part of the plain. Coll. 1958 and subm. by W. E. Davies, U. S. Geological Survey, Washington, D. C.

\section{W-757. Djebus, Indonesia}

Wood from tree buried under a few $\mathrm{m}$ of river alluvium in the drowned valley of the Tjupat River, Klabat Bay, Djebus $\left(1^{\circ} 45^{\prime} \mathrm{S}\right.$ Lat, $105^{\circ} 25^{\prime} \mathrm{E}$ Long), Northwest Bangka, Indonesia. Coll. 1956 and subm. by R. Osberger, Bangka Tin Mining Co., Pangkalpinang, Bangka, Indonesia.

\section{Eniwetok Atoll series, Marshall Islands}

Two core samples from drill holes on Eniwetok Atoll, dated to compare the $\mathrm{C}^{14}$ results with the ages determined by the ionium-uranium ratio dating method developed by H. A. Potratz, Washington University, St. Louis, Missouri. Coll. 1952 by H. S. Ladd, U. S. Geological Survey, Washington, D. C.; subm. by Potratz.

\section{W-619. Muzinkarikku Island}

$3840 \pm 300$

Core sample (no. Mu 7-4) from 13- to 24-ft level, from drill hole on NE part of Muzinkarikku Island ( $11^{\circ} 28^{\prime} \mathrm{N}$ Lat, $162^{\circ} 12^{\prime} \mathrm{E}$ Long), Eniwetok Atoll. Altitude of drill hole, $8.5 \mathrm{ft}$; sample from 5 to $16 \mathrm{ft}$ below sealevel. Age by ionium-uranium ratio method, $8400 \pm 1200$ (Sackett, 1958).

W-620. Engebi Island

$2700 \pm 250$

Core sample (no. 13-3) from depth of 9.0 to $10.5 \mathrm{ft}$ from foundation of test hole near center of Engebi Island ( $11^{\circ} 33^{\prime} \mathrm{N}$ Lat, $162^{\circ} 12^{\prime} \mathrm{E}$ Long), 
Eniwetok Atoll. Altitude unknown, but probably near $8 \mathrm{ft}$. Sample is bedded rock similar to beach rock, and a little below sealevel. Age by ionium-uranium ratio method, $6300 \pm 1200$ (Sackett, 1958).

Utirik Atoll series, Marshall Islands

Soil and shells from profile dug in a coconut plantation back of Utirik village, Utirik Islet, Utirik Atoll ( $11^{\circ} 22^{\prime} \mathrm{N}$ Lat, $169^{\circ} 45^{\prime} \mathrm{E}$ Long), Marshall Islands. Collected to investigate rate of accumulation of humified layers in atoll soils. Coll. 1956 and sulm. by F. R. Fosberg, U. S. Ceological Survey, Washington, D. C.

W-764. Utirik, 316-1

Black sandy loam from upper 13 in of a section of Arno Atoll series soil, basically calcium carbonate soil with considerable humus.

W-763. Utirik, 316-3

$3270 \pm 200$

Foraminiferal sand lying between 18 and $48 \mathrm{in.}$, in same profile as $\bar{W} \cdot 764$.

\section{W-588. Ishigaki-shima, Ryükyü-rettö}

$\mathbf{8 5 0 0} \pm \mathbf{5 0 0}$

Bone fragments from wild boar, from bench along the $\mathrm{S}$ side of the Todoroki-gawa, Ishigaki-shima $\left(24^{\circ} 20^{\prime} 30^{\prime \prime} \mathrm{N}\right.$ Lat, $124^{\circ} 10^{\prime} 51^{\prime \prime}$ E Long), Ryükyu-retto. The bone fragments occur on a bench $21 \mathrm{ft}$ above the level of the present valley floor of the Todoroki-gawa and ca. $40 \mathrm{ft}$ above sealevel. The bench is composed of silty stream-terrace deposits that are plastered against a cliff of Ryükyü (Pleistocene age) limestone. Ryükyu limestone also overhangs the bench. The silt also contains land snails and some marine shells. Coll. 1956 by H. L. Foster and H. G. May; subm. by F. C. Whitmore, Jr., all of the I. S. Geological Survey, Washington, D. C.

\section{W-613. Kainan, Ishigaki-shima, Ryükü-rettö}

Wood fragments surrounded by gray sandy clay exposed on NW bank of the E branch of the Nagura-gawa, ca. $1 \mathrm{mi} \mathrm{NW}$ of the village of Kainan $\left(24^{\circ}\right.$ $24^{\prime} 08^{\prime \prime} \mathrm{N}$ Lat, $124^{\circ} 10^{\prime} 50^{\prime \prime}$ E Long), Ishigaki-shima, Ryükyu-retto. From a layer of wood fragments in a gray clay that is unconformably overlain by coarse stream-terrace deposits consisting of boulders of granite, diorite, and Paleozoic chert in a matrix of yellowish sandy clay. The contact ranges from 20 to $40 \mathrm{~m}$ ahove sealevel. Coll. 1956 and subm. by H. L. Foster, U. S. Geological Survey, Washington, D. C.

\section{W-760. (Ozato, Ishigaki-shima, Ryukyu-retto}

$990 \pm 180$

Peat from bog in the marshy headwaters of the Miyara-gawa, ca. $1.3 \mathrm{mi}$ W of the village of ( 'zato $\left(24^{\circ} 24^{\prime} 50^{\prime \prime} \mathrm{N}\right.$ Lat, $124^{\circ} 13^{\prime} 30^{\prime \prime} \mathrm{E}$ Long), Ishigakishima, Ryukyu-retto. Sample is from depth of 10 to $11 \mathrm{ft}$. Peat deposition is post-valley cutting of the Nagura gravel. Coll. 1956 by C. Stensland; subm. by H. I. Foster, U. S. Ceological Survey, Washington. D. C.

\section{Páramo de Palacio series, Colombia}

Peat from two peat bogs that have been subjected to detailed pollen analysis by the collector; taken from cores at Páramo de Palacio, near the La Siberia-Palacio road $\left(4^{\circ} 15^{\prime} \mathrm{N}\right.$ Lat, $74^{\circ} 00^{\prime} \mathrm{W}$ Long), Eastern Cordillera, Dept. Cundinamarca, Colombia. Samples, taken from bogs at $3550 \mathrm{~m}$ altitude, 
were collected to determine the contemporaneity of the wet and dry phases of the Holocene in Europe and South America. Coll. 1958 by T. van der Hammen, Instituto Geologico Nacional, Bogotá, Colombia; subm. by R. F. Flint, Yale University, New Haven, Connecticut.

W-783. Peat bog Pi I, no. 16

$2950 \pm 200$

Peat from depth of 80 to $82 \mathrm{~cm}$ below surface. Represents beginning of a wet climatic phase corresponding to the beginning of the Sub-Atlantic in Europe.

W-781. Peat bog Pt. I, no. 15

$4740 \pm 160$

Peat from depth of 116 to $120 \mathrm{~cm}$ below surface, at base of bog.

W-785. Peat bog Pt. II, no. 14

$\mathbf{2 7 0 0} \pm \mathbf{2 0 0}$

Peat from depth of 60 to $62 \mathrm{~cm}$ below surface; same climatic fluctuation as W-783.

W-782. Peat bog Pt. II, no. 13

$7210 \pm 220$

Peat from depth of 123 to $127 \mathrm{~cm}$ below surface, at base of bog.

\section{Stratosphere carbon dioxide series}

Carbon dioxide was collected at 50,000 ft altitude during the period from January 1956 through December 1957 at latitude $32^{\circ} \mathrm{N}$ in the United States. Radiocarbon activity was compared with that of two standards used in this laboratory. There was not enough gas to fill our counter, so the sample was diluted by less than one-half with a gas of known activity. Statistical counting error for the run is $\pm 1 \%$. Sample subm. by H. Wexler and L. Machta, U. S. Weather Bureau, Washington, D. C.

W-708. Ratio of stratospheric air to 1890 wood 1.253 standard, age corrected

W-708A. Ratio of National Bureau of Standards oxalic-acid standard to 1890 wood standard, age corrected

\section{W-708/708A. Ratio of stratospheric air to NBS} oxalic-acid standard

In short, the "strotosphere" is about $25 \%$ higher in activity than what present wood, or troposphere air, would be if uncontaminated by nuclear explosions and burning of fossil fuels. For complete discussion of stratosphere $\mathrm{C}^{14}$, sec Hagemann and others (1959).

\section{ARCHAEOLOGIC SAMPLES \\ A. North America}

\section{W-798. Seneca Creek, Maryland}

$1960 \pm 160$

Charcoal from fire pit near mouth of Seneca Creek, ca. 300 ft from junclure of creek and Potomac River, near Seneca $\left(39^{\circ} 04^{\prime} \mathrm{N}\right.$ Lat, $77^{\circ} 21^{\prime} \mathrm{W}$ Long), Montgomery County, Maryland. Fire pit is in brown silt under 9 to 11 in. of soil, located on what was an island in the Seneca Creek delta at the time of occupation by the Woodland Indians. Hundreds of points, scrapers, and pieces of pottery have been unearthed by the excavators of the site, the Southwestern Chapter of the Archeology Society of Maryland. Coll. 1958 by 
W. Tidwell of the Society; subm. by J. Cood and J. Corbett, National Park Service, Washington, D. C.

W-636. Pigeon Cliffs, New Mexico

Charcoal from buried soil at Pigeon Cliffs archaeologic site, Cienequilla Creek, $12 \mathrm{mi} \mathrm{NW}$ of Clayton, in SE $1 / 4 \mathrm{NW} 1 / 4$ sec. 15, T $27 \mathrm{~N}, \mathrm{R} 34 \mathrm{E}\left(36^{\circ}\right.$ $36^{\prime} \mathrm{N}$ Lat, $103^{\circ} 18^{\prime} \mathrm{W}$ Long), Union County, New Mexico. From a hearth at 5 ft depth, associated with archaic stone implements and fossil bison. For complete site description, see Steen (1955). Coll. 1955 by C. R. Steen, National Park Service, Santa Fe, New Mexico; subm. by B. T. Gale, National Park Service, Washington, D. C.

\section{W-543. Jamesport, Long Island, New York}

Charcoal from and near hearth in large ceremonial pit, Jamesport Hill site, on hill marked by U. S. Coast and Geodetic Survey marker 1939, James. port, Long Island $\left(40^{\circ} 57^{\prime} \mathrm{N}\right.$ Lat, $72^{\circ} 35^{\prime} \mathrm{W}$ Long), New York. From white sand at 30 to $50 \mathrm{in}$., in direct or close association with a burial offering of "killed" steatite pots, fishtail-type projectile points, and other characteristic artifacts of the Orient Focus, believed to be transitional into Early Woodland I Period. Depicts introduction of burial cult, first use of ceramics and other important traits into eastern New York and New England area. Coll. 1953 and subm. by W. A. Ritchie, New York State Science Service and State Museum, Albany, through Frederick Johnson.

\section{W-545. Frontenac Island, New York}

45. Frontenac Island, New York
Charcoal from hearth in Frontenac Island site, Trench 9, section $2,\left(42^{\circ}\right.$ $51^{\prime} \mathrm{N}$ Lat, $76^{\circ} 42^{\prime} \mathrm{W}$ Long), Cayuga County, New York. Hearth at depth of 20.5 in., attributed to the Frontenac Focus. For site description, see Ritchie (1945). Coll. 1953 and subm. by W. A. Ritchie, New York State Science Service and State Museum, Albany, through Frederick Johnson.

\section{Barlovento series, Colombia}

\section{B. Central and South America}

Marine shells (Melongena melongena Linnaeus) collected from three layers in the midden, mound $\mathrm{E}$, at Barlovento $\left(11^{\circ} 10^{\prime} \mathrm{N}\right.$ Lat, $75^{\circ} 00^{\prime} \mathrm{W}$ Long), Dept of Atlantico, Colombia. The Barlovento site is culturally of the Formative Period and relates to the Guanape site of Peru and the Valdivia of coastal Ecuador. All three sites are the result of midden accumulation from living on marine shellfish. Coll. 1957 by G. Reichel-Dolmatoff; subm. by C.

Evans, U. S. National Museum, Washington, D. C.

$$
\begin{array}{lll}
\text { W-741. Upper level, } 1 \mathrm{~m} \text { depth } & 2980 \pm 120 \\
\text { W-743. } & \text { Middle level, } 3 \mathrm{~m} \text { depth } & 3140 \pm 120 \\
\text { W-739. } & \text { Bottom level, } 6 \mathrm{~m} \text { depth } & 3170 \pm 120
\end{array}
$$

\section{Manabi Province series, Ecuador}

Jaramijo) on Ecuador. Samples came from hearthince $\left(0^{\circ} 57^{\prime} \mathrm{S}\right.$ Lat, $80^{\circ} 39^{\prime} \mathrm{W}$ Long), the early Bahia Period, from hearth and midden refuse and should date from 
tion. Coll. 1957 by E. Estrada; subm. by C. Evans, U. S. National Museum, Washington, D. C.

W-834. Estero no. 1, 109

$2200 \pm 240$

Charcoal from 40 to $80 \mathrm{~cm}$ depth.

W-833. Estero no. 1, 415

$2150 \pm 240$

Charcoal from 280 to $320 \mathrm{~cm}$ depth.

\section{Valdivia series, Ecuador}

Shells from Valdivia culture phase, from slight promontory near coastline between villages of San Pedro and Valdivia, on $\mathrm{S}$ side of the Valdivia River valley ( $1^{\circ} 56^{\prime} \mathrm{S}$ Lat, $80^{\circ} 45^{\prime} \mathrm{W}$ Long), Guayas Province, Ecuador. The Valdivia phase is the earliest Formative Period material from Ecuador. Ceramically this is related to the Formative of Mexico (especially Tlatilco) and the Formative of Peru (especially the Guanape, Chavin, and Cupisnique). Coll. 1957 and subm. by C. Evans and B. Meggers, U. S. National Museum, Washington, D. C.

\section{W-630. Valdivia, Cut H}

$4050 \pm 200$

Shells from terminal of Valdivia phase at 1.3. to 1.4-m level.

W-632. Valdivia, Cut A
Shells from terminal of Valdivia phase at 1.2 - to $1.4-\mathrm{m}$ level.

W-631. Valdivia, Cut $A \quad 4450 \pm 200$ Shells from earliest part of Valdivia phase at 4.0- to 4.2-m level.

\section{W-835. Guayas Province, Ecuador}

$\mathbf{7 6 0} \pm \mathbf{5 0 0}$

Charcoal from hearths in excavations at Puerto Chanduy $\left(2^{\circ} 25^{\prime} \mathrm{S}\right.$ Lat, $80^{\circ} 40^{\prime} \mathrm{W}$ Long), Guayas Province, Ecuador. Taken from a depth of 50 to $60 \mathrm{~cm}$; should date transition to Early Manteno Period, as shown from the analysis of the pottery. Some rootlets apparent at sample horizon. Sample was insufficient, which acounts for the large error quoted. Coll. 1957 by C. Evans, B. J. Meggers, and E. Estrada; subm. by Evans, U. S. National Museum, Washington, D. C.

\section{La Victoria series, Guatemala}

Shells from midden refuse at La Victoria site, near Ocos $\left(14^{\circ} 30^{\prime} \mathrm{N}\right.$ Lat, $92^{\circ} 12^{\prime} \mathrm{W}$ Long), Retalhuleu Dept., Guatemala. Site is $1.5 \mathrm{~km}$ from present Pacific Coast but is on old beach lines. In the 4-m section of the site, four different culture horizons are well defined: Marcos Phase (most recent), Cruzero Phase, Conchas Phase, and Ocos Phase at base. Coll. 1958 by M. D. Coe; subm. by C. Evans, U. S. National Museum, Washington, D. C.

W-836. La Victoria, level 11, Conchas Phase $2150 \pm 240$

Panama jacknife clams from 3.0 to $3.3 \mathrm{~m}$ depth.

W-837. La Victoria, level 12, Conchas Phase $2080 \pm 240$

Panama jacknife clams from 3.3 to $3.6 \mathrm{~m}$ depth.

W-707. Dzibilchaltun, Yucatan, Mexico $\quad 1450 \pm 200$

Piece of subinche wood, from the "Temple of the Seven Dolls," in the ancient Mayan city of Dzibilchaltun $\left(21^{\circ} 05^{\prime} \mathrm{N}\right.$ Lat, $89^{\circ} 30^{\prime} \mathrm{W}$ Long $)$, Northern Yucatan, Mexico. Taken from a beam forming the lintel over a doorway 
in the inner temple. Description of site appears in an article by Andrews (1959). Coll. 1958 by E. W. Andrews; subm. by L. J. Briggs, National Ceographic Society, Washington, D. C.

\section{Miscellaneous}

\section{Near Eastern prehistory series}

Samples bearing on the problem of the appearance of the settled villagefarming community in the Near East were undertaken at the request of R. J. Braidwood, Oriental Institute, University of Chicago, who submitted the samples. F. R. Matson, Pennsylvania State University, had collected the samples, using extreme care, with the express intention of having them dated. Most of the samples were collected with clean trowels and spatulas and placed immediately into polyethylene bags and sealed. The samples were processed in the Washington laboratory with an acid-alkali-acid treatment to remove humic acids. Only the alkali-insoluble fraction of the sample was used. There remains a wide range in the ages determined for samples from the same locality. Contamination of the samples by the addition of foreign carbon is suspected. Isotopic fractionation was checked by mass-spectrometer measurements of $\mathrm{C}^{12} /$ $\mathrm{C}^{13}$ at the University of Chicago Institute for Nuclear Studies by Mrs. Toshiko $K$. Mayeda, and found to be insignificant. The ratios were measured on samples reconverted to $\mathrm{CO}_{2}$ after making acetylene for the $\mathrm{C}^{1+}$ run. The ages were corrected to a standard $\mathrm{C}^{12} / \mathrm{C}^{13}$ ratio of $\delta-25.00 \%$, but the correction did not exceed $100 \mathrm{yr}$ in any sample. A complete summary of the dates, map of site locations, discussion of the significance of the dates, and photographs of the collecting areas appear in an article by Braidwood (1958).

\section{W-607. Jarmo village, PQ-14}

$9040 \pm 250$

Jarmo, an ancient village site, $30 \mathrm{mi} \mathrm{E}$ of Kirkuk ( $35^{\circ} 36^{\prime} \mathrm{N} \mathrm{Lat}, 44^{\circ} 48^{\prime}$ E Long), in NE Iraq. The sample consists of hearth material from a dark band in a trench profile $120 \mathrm{~cm}$ below base line, II-7, no. 54. Coll. 1955. $\mathrm{C}^{12} / \mathrm{C}^{13}$ ratio $=\delta-19.86 \%$.

W-608. Jarmo village, PQ-14, humic fraction

$\mathbf{7 7 5 0} \pm \mathbf{2 5 0}$

Same charcoal flecks as W-607, but only the fraction soluble in alkali was used. Difference in age indicates the intrusion of younger carbon in the form of humic acid. $\mathrm{C}^{12} / \mathrm{C}^{13}$ ratio $=\delta-29.52 \%$.

W-657. Jarmo village, PQ-14

Sample no. 55, from $225 \mathrm{~cm}$, coll. 1955.

W-665. Jarmo village, N-18

Sample no. 53, from $200 \mathrm{~cm}$, coll. 1955.

W-651. Jarmo village, J-II-4

Coll. 1951.

\section{W-6.52. Jarmo village, J-I-7a}

W-609. Hassuna village, level la

$11,240 \pm 300$

Hassuna, an early village site, $22 \mathrm{mi} \mathrm{S}$ of Mosul. $1 \mathrm{mi} \mathrm{W030 \pm 200}$ River $\left(36^{\circ} 6^{\prime} \mathrm{N}\right.$ Lat, $43^{\circ} 12^{\prime} \mathrm{E}$ Long $)$, northern Iraq. Sample consists of hearth charcoal from level Ia, no. 6, coll. 1954. $\mathrm{C}^{12} / \mathrm{C}^{13}$ ratio $=\delta-19.36 \%$. 
W-660. Hassuna village, level 5

Charcoal from 5th level, no. 7, coll. 1955.

$\mathbf{7 5 7 0} \pm \mathbf{2 5 0}$

W-623. Matarrah village, no. 2

Matarrah, an early village, $34 \mathrm{~km} \mathrm{~S}$ of Kirkuk, $3 \mathrm{~km} \mathrm{~W}$ of the Kirkuk-
had road $\left(35^{\circ} 12^{\prime} \mathrm{N}\right.$ Lat, $44^{\circ} 24^{\prime} \mathrm{E}$ Long $)$, northern Iraq. Sample conBaghdad road $\left(35^{\circ} 12^{\prime} \mathrm{N}\right.$ Lat, $44^{\circ} 24^{\prime} \mathrm{E}$ Long $)$, northern Iraq. Sample con-
sists of charcoal lumps from dark band of burned layer in operation VI-4. Modern rootlets, mold, insect eggs, and scorpion droppings were noted in the sample. Coll. 1954. $\mathrm{C}^{12} / \mathrm{C}^{13}$ ratio $=\delta-20.23 \%$.

W-627. Byblos village A, no. 32

$6550 \pm 200$

Byblos is on the seacoast, $37 \mathrm{~km} \mathrm{~N}$ of Beirut at the present town of Jubail (34 $12^{\prime} \mathrm{N}$ Lat, $35^{\circ} 36^{\prime} \mathrm{E}$ Long), Lebanon. Sample is part of a charred log beneath the floor of the lowest Neolithic level. Coll. 1955. $\mathrm{C}^{12} / \mathrm{C}^{13}$ ratio $=$ $\delta-27.18 \%$.

W-617. Mersin village, basal layer, no. 41

$\mathbf{7 9 5 0} \pm \mathbf{2 5 0}$

Mersin is on the southern coast of Turkey, due $\mathrm{N}$ of the eastern tip of Cyprus. The ancient mound is on the edge of the present town $\left(36^{\circ} 48^{\prime} \mathrm{N}\right.$ Lat, $34^{\circ} 31^{\prime} \mathrm{E}$ Long), Turkey. Taken from the river-cut $\mathrm{E}$ face of the mount, Yarmuk Tepe, $1 \mathrm{~m}$ above river level. It consisted of large chunks of charcoal occurring in a black band, 1 to $2 \mathrm{~cm}$ wide, extending across the $\mathrm{E}$ face just below the bottom of trench $\mathrm{A}$. This represents the basal settlement level in Asia Minor. Coll. 1955. $\mathrm{C}^{12} / \mathrm{C}^{13}$ ratio $=\delta-29.29 \%$.

\section{Shanidar series, Iraq}

Charcoal samples from cultural horizons in Shanidar Cave, near the present village of Shanidar $\left(36^{\circ} 50^{\prime} \mathrm{N}\right.$ Lat, $44^{\circ} 20^{\prime} \mathrm{E}$ Long $)$, Erbil Liwa, northern Iraq, and from an early Neolithic village site called Zawi Chemi Shanidar, $4 \mathrm{k}$ to the NW. Because the same material culture was found in the upper stratigraphy of Shanidar Cave as at the village site, contemporary or seasonal occupation is assumed at both sites. Shanidar Cave has yielded a remarkable assemblage of cultural artifacts from several layers of occupation and includes several complete skeletons of Neanderthal adults. The Cave exhibits four major cultural layers. From top to bottom, these are: Layer A, Recent to Neolithic; Layer B, Mesolithic to very late upper Paleolithic (Zarzi); Layer C, upper Paleolithic Aurignacian-like (Baradostian); and Layer D, middle Paleolithic Mousterian (Hazer Merd). The complete description of the Cave and village findings and discussion of the dates appear in the reports by the collector of the samples, R. S. Solecki, formerly with the U. S. National Museum, Washington, D. C., and presently at Columbia University, New York (1955, 1957a, 1957b; Solecki and Rubin, 1958a, 1958b).

W-662. Shanidar Cave, no. 64

Charcoal from hearth in Layer A, 4 to 5 ft from surface. Cave is occupied even to the present by sheepherders.

W-667. Shanidar Cave, IV, 5

$10,600 \pm 300$

Charcoal flecks from zone B 1, top of Layer B. 
W-654. Shanidar Cave, no. 186

$28,700 \pm 700$

Charcoal from hearth at depth of $2.35 \mathrm{~m}$ below zero datum at top of Layer C.

W-650. Shanidar Cave, no. 213

$33,300 \pm 1000$

Charcoal from hearth at $3.3 \mathrm{~m}$ below zero datum at top of Layer C.

W-681. Zawi Chemi Shanidar, no. $455 \quad 10,800 \pm 300$

Charcoal from streak of hearth at $120 \mathrm{~cm}$ below surface in Layer B, prepottery, early Neolithic horizon.

W-655. Antelas, Portugal

$1380 \pm 300$

Charcoal from megalithic dolmen of granite at Antelas, Oliveira de Frades $\left(40^{\circ} 47^{\prime} \mathrm{N}\right.$ Lat, $8^{\circ} 12^{\prime} \mathrm{W}$ Long), Portugal. Found in the interior of the dolmen. Coll. 1956 by V. Ferreira and A. Castro; subm. by A. de Castello Branco, Geological Survey of Portugal, Lisbon. The submitter suspects that the site was violated and that the charcoal is more recent than the station.

W-656. Penha Verde, Portugal

$3420 \pm 200$

Charcoal from prehistoric monument at Penha Verde, Sintra Mountains, near Lisbon ( $38^{\circ} 50^{\prime} \mathrm{N}$ Lat, $9^{\circ} 20^{\prime} \mathrm{W}$ Long), Portugal. The walls of the monument are of limestone. Coll. 1956 by D. Zybszewski and V. Ferreira; subm. by A. de Castello Branco, Geological Survey of Portugal, Lisbon.

Date lists:

REFERENCES

Chicago I. Arnold and Libby, 1951

Lamont III. Broecker, Kulp, and Tucek, 1956

Lamont V. Olson and Broecker, 1959

Uppsala II. Olsson, 1960

USGS I. Suess, 1954

USGS II. Rubin and Suess, 1955

USGS IV. Rubin and Alexander, 1958

Yale III. Barendsen, Deevey, and Gralenski, 1957

Andrews, E. W., 1959, Dzibilchaltun: the lost city of the Maya: Nat. Geog. Mag., v. 115, p. $90-109$.

Arnold, J. R., and Libby, W. F., 1950, Radiocarbon dates: Science, v. 113, p. 111-120.

Barendsen, G. W. Deevey, E. S., and Gralenski, L. J., 1957, Yale natural radiocarbon measurements III. Science, v. 126, p. 908-919.

Black, R. F., 1958, Glacial geology of Lake Genera area, southeast Wisconsin [abs.]: Geol. Soc. America Bull., v. 69, p. 1536.

1959, Glacial geology of west-central Wisconsin: Guidebook, 10th Ann. Field Conf., Midwestern Friends of the Pleistocene, Stop 2, University of Wisconsin, Madison.

Braidwood, R. J. 1958, Near Eastern prehistory: Science, v. 127, p. 1419-1430.

Briggs, L. C., 1951, Aperçu préliminaire sur le gisement préhistorique de Kouali: Soc. Histoire Nat. de l'Afrique du Nord Bull. [Algiers], v. 42, p. 30-32.

Broecker, W. S., Kulp, J. L., and Tucek, C. S., 1956, Lamont natural radiocarbon measurements III: Science, v. 124, p. 154-165.

Browne, W. R., 1952, Pleistocene graciation in the Kosciusko region: Sir Douglas Mawson Anniversary Vol., University of Adelaide, p. 25-4l.

Buter, Patrick, 1959, Palynolorical studies of the Barnstable Marsh, Cape Cod, Massachusetts: Ecology. v. 40, p. 735-737. 
Goldthwait, R. P., 1955, Pleistocene chronology of southwestern Ohio: Guidebook, 5th Bienn. Pleistocene Field Conf., Ohio-Indiana, Ohio State University, Columbus.

Hack, J. T., 1941, Dunes of the western Navajo country: Geog. Rev., v. 31, no. 2, p. 240263.

Hagemann, F., Gray, J., Machta, L., and Turkevich, A., 1959, The stratospheric content of carbon-14, carbon dioxide and tritium: Science, v. 130, p. 542-552.

Karlstrom, T. N. V., in preparation.

Lane, G. H., 1931, A preliminary analysis of the East MoCulloch peat bed: Ohio Jour. Sci., v. 31, p. 165-171.

Miller, R. D., and Scott, G. R., 1955, Sequence of alluviation along the Loup River, Valley Country area, Nebraska: Geol. Soc. America Bull., v. 66, p. 14311-1448.

Moir, D. R., 1957, An occurrence of buried coniferous wood in the Altamont moraine in North Dakota: North Dakota Acad. Sci. Proc., v. 11, p. 10.

Olson, E. A., and Broecker, W. S., 1959, Lamont natural radiocarbon measurements V: Am. Jour. Sci. Radioc. Supp., v. 1, p. 1-28.

Olsson, Ingrid, 1960, Uppsala natural radiocarbon measurements II: AM. Jour. Scr. Radioc. Supp., v. 2, p. 1112-128.

Péwé, T. L., Rivard, N., and Llano, G. A., 1959, Mummified seal carcasses in the McMurdo Sound region, Antarctica: Science, v. 130, p. 716.

Ritchie, W. A., 1945, An early site in Cayuga County, New York: Rochester Museum of Arts and Sciences Res. Rec. 7.

Romer, A. S., 1951, Bison crassicornis in the Pleistocene of New England: Jour. Mammalogy, v. 32, p. $230-231$.

Rubin, Meyer, and Allexander, Corrinne, 1958, U. S. Geological Survey radiocarbon dates IV: Science, v. 127, p. 1476-1487.

Rubin, Meyer, and Suess, H. E., 1955, U. S. Geological Survey radiocarbon dates II: Science, v. 121, p. $481-488$.

Ruhe, R. V., Rubin, Meyer, and Scholtes, W. H., 1957, Late Pleistocene radiocarbon chronology in Iowa: Am. Jour. SCI., v. 255, p. 671-689.

Ruhe, R. V., and Scholtes, W. H., 1959, Important elements in the classification of the Wisconsin glacial stage: a discussion: Jour. Geology, v. 67, p. 585-593.

Sackett, W. M., 1958, Ionium-uranium ratios in marine deposited calcium carbonates and related materials: Thesis, Washington University, Dept. of Chemistry, St. Louis, Missouri.

Schultz, C. B., Lueninghoener, G. C., and Frankforter, W. D., 1951, A graphic resume of the Pleistocene of Nebraska: Nebraska Univ. State Mus. Bull., v. 3, p. 1-41.

Solecki, R. S., 1955, Shanidar Cave, a Paleolithic site in northern Iraq: Smithsonian Institution Report for 1954, p. 389-425.

1957a, Two Neanderthal skeletons from Shanidar Cave: Sumer, v. 13, p. 59-60. 1957b, Shanidar Cave: Sci. American, v. 197, p. 58-64.

Solecki, R. S., and Rubin, Meyer, 1958a, Dating of Zawi Chemi, an early village site at Shanidar, northern Iraq : Science, v. 127, p. 1446.

1958b, Grant No. 2086: Am. Philos. Soc. Yearbook [1958], p. 403-407.

Steen, C. R., 1955, The Pigeon Cliffs site: a preliminary report: El Palacio, v. 62, p. 174 180 .

Suess, H. E., 1954, U. S. Geological Survey radiocarbon dates I: Science, v. 120, p. $467-$

473.
Thornbury, W. D., and Wayne, W. J., 1953, Guidebook of Joint Illinois-Indiana Field Conference; Indiana Itinerary: Printed for the Illinois and Indiana State Geological Surveys.

1957, Guidebook, 8th Ann. Field Conference, Midwestern Friends of the Pleistocene: Indiana University, Bloomington.

Wanless, H. R., 1957, Geology and mineral resources of the Beardstown, Glasford, Havana and Vermont quadrangles: Illinois State Geol. Survey Bull. 82.

Wright, H. E., Jr., and Rubin, M., 1956, Radiocarbon dates of Mankato drift in Minnesota: Science, v. 124, p. 625-626. 